\title{
SECONDARY CARIES, MIND THE GAP!
}

\author{
Nicolien Kuper
}




\section{ISBN}

978-94-6259-567-5

\section{Cover}

J.L. Ruben

\section{Design and lay-out}

Promotie In Zicht, Arnhem, The Netherlands

\section{Print}

Ipskamp Drukkers, Enschede, The Netherlands

\section{(C) 2015 Nicolien K. Kuper}

All rights reserved. No parts of this publication may be reproduced or transmitted in any form or by any means, electronic or mechanical, including photocopy, recording or otherwise, without prior written permission of the author. 


\section{SECONDARY CARIES, MIND THE GAP!}

\section{Proefschrift}

ter verkrijging van de graad van doctor aan de Radboud Universiteit Nijmegen op gezag van de rector magnificus prof. dr. Th.L.M. Engelen, volgens besluit van het college van decanen in het openbaar te verdedigen op donderdag 19 maart 2015 om 12.30 uur precies

door

\section{Nicolien Klaassien Kuper}

geboren op 24 augustus 1985

te Emmen 


\section{Promotor}

Prof. dr. M.C.D.N.J.M. Huysmans

\section{Copromotor}

Dr. N.J.M. Opdam

\section{Manuscriptcommissie}

Prof. dr. J.A. Jansen

Prof. dr. C. van Loveren (ACTA/UvA)

Prof. dr. H. Meyer-Lückel (RWTH Aachen University, Duitsland) 


\section{Contents}

$\begin{array}{lll}\text { Chapter } 1 & \text { General introduction } & 7\end{array}$

Chapter 2 The influence of approximal restoration extension on the 19 development of secondary caries

Kuper NK, Opdam NJM, Bronkhorst EM, Huysmans MCDNJM Journal of Dentistry 2012; 40(3): 241-247

Chapter 3 Restoration materials and secondary caries using an in vitro biofilm model

Kuper NK, van de Sande FH, Opdam NJM, Bronkhorst EM, de Soet JJ, Cenci MS, Huysmans MCDNJM Journal of Dental Research 2015; 94(1): 62-68

Chapter 4 Secondary caries development in in situ gaps next to composite and amalgam

Kuper NK, Montagner AF, van de Sande FH, Bronkhorst EM, Opdam NJM, Huysmans MCDNJM

Submitted

Chapter 5 Gap size and wall lesion development next to composite Kuper NK, van de Sande FH, Opdam NJM, Bronkhorst EM, de Soet JJ, Cenci MS, Huysmans MCDNJM Journal of Dental Research 2014; 93(7 suppl): 108S-113S

Chapter 6 Hydrodynamic flow through loading and in vitro secondary caries development Kuper NK, Opdam NJM, Bronkhorst EM, Ruben JL, Huysmans MCDNJM Journal of Dental Research 2013; 92(4): 383-387

Chapter 7 General discussion

Chapter 8 Summary

Chapter 9 Samenvatting 

1

General introduction 



\section{General introduction}

Dental caries is a disease that causes demineralization and destruction of the hard tissues (enamel, dentin, cementum) of the teeth. Dental caries may develop at any tooth site in the oral cavity where a biofilm is able to develop and thrive for a period of time. The biofilm, often referred to as dental plaque, is a prerequisite for caries lesions to occur. During consumption of meals which contain fermentable carbohydrates, the metabolic activity of the biofilm can be enhanced and recorded as $\mathrm{pH}$ fluctuations. When the $\mathrm{pH}$ drops below a critical level the chemical composition of the hard tissue underneath the biofilm changes and demineralizes. When the $\mathrm{pH}$ rises again the tooth can remineralize. When $\mathrm{pH}$-drops are frequent, the physiological equilibrium between tooth mineral and biofilm fluid will be disturbed and the remineralization will be outstripped by demineralization, resulting in a net mineral loss and lesion formation.

When caries develops at a tooth surface that was previously unaffected, it is defined as primary caries. Secondary caries or recurrent caries lesions develop at a location adjacent to an existing restoration. These two terms are synonyms, but in this thesis we will use the term secondary caries throughout. Residual caries is demineralized, carious tissue that has been left behind intentionally or unintentionally before a restoration is placed. Clinically, it is often difficult or impossible to distinguish between secondary caries and residual caries.

\section{Secondary caries versus primary caries}

Secondary caries is one of the reasons most frequently reported in relation to failure and replacement of restorations (Mjör, 2005; Bernardo et al., 2007; Opdam et al., 2007). Some researchers believe that the secondary caries process is essentially the same as primary caries, only now located at the margins of existing restorations (Kidd and Fejerskov, 2004). When the marginal areas of a restoration deteriorate with time, this may result in the existence of a gap or defect at the cavity wall. Subsequently a biofilm can establish itself in this defect along the tooth-restoration interface and secondary caries can develop within the gap. If secondary caries is considered as also primarily the result of marginal failure of restorations, it explains why restorations with defective margins have often been recommended to be replaced, even where caries had not actually developed yet.

The in vitro study of Hals and Nernaes (1971) describes that secondary caries lesions consist of two regions. These have been designated as the outer lesion and the cavity wall lesion, see Figure 1.1. The outer lesion has a progressing front parallel to the outer surface of the tooth surface and is histologically similar to a primary lesion. The wall lesion develops at the interface between restoration and tooth and progresses perpendicularly to the tooth-restoration interface. Although the basic etiology 
of secondary caries is no different from primary caries, there are many factors that make secondary caries special and probably different from primary caries.

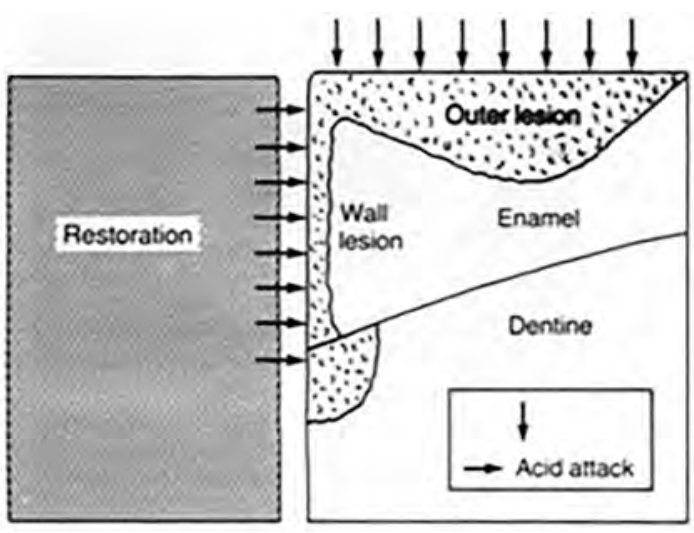

Figure 1.1 Schematic representation of a secondary caries lesion, showing the outer lesion and the wall lesion

\section{Microleakage, macroleakage and gaps}

The current literature available does not precisely determine the mechanism of initiation and progression of secondary caries lesions. It has been discussed whether secondary caries would initiate on the external surface and progress to the gap between tooth structure and restoration and / or would (also) be started within this interface by the diffusion of bacteria or their products (Sarrett, 2005; Totiam et al., 2007; Cenci et al., 2009; Imazato, 2009).

For a long time wall lesions were assumed to develop as a result of microleakage between restoration and tooth. According to this theory the microspace between restoration and tooth can be filled rapidly with salivary pellicle allowing bacteria and their products to invade. Mostly, in vitro studies showed that through microleakage in small microspaces (50 microns and less), bacterial acids could leak in at the tooth-restoration interface and could be sufficient to cause demineralization and wall lesions (Jørgensen and Wakumoto, 1968; Goldberg et al., 1981; Dérand et al., 1991; Hodges et al., 1995; Totiam et al., 2007). This microleakage theory assumes that a wall lesion can develop in any gap, but the wider the gap, the higher the risk that it will occur. However, clinical studies show that microleakage is not associated with secondary caries (Kidd et al., 1995; Thomas et al., 2007). Also a review of Heintze (2007) showed that there is no correlation between clinical performance and 
microleakage in vitro of restorations. This has changed the view of cariologists and therefore the emphasis is put more on the presence of an active biofilm for development of secondary caries. Accordingly, it is thought that a wall lesion cannot develop as long as no active biofilm of plaque can grow along the tooth-restoration interface, which is only possible when large gaps or cavitations are present. The width of the gap needed for such a cariogenic biofilm has been roughly estimated to be 400 micrometer (Kidd et al., 1995) or 225 micrometer (Thomas et al., 2007). As wall lesions formed in vivo have only been found in relation to large voids or gaps, it was proposed to describe leakage that results in wall lesion development rather as 'macroleakage' instead of microleakage (Mjör, 2005).

However, we cannot conclude anything yet about what size of gap would be clinically relevant for secondary caries development. The study of Kidd et al. (1995) estimated a gap width of 400 micrometer by probing defective margins of restorations with a periodontal probe. If the probe $(400 \mu \mathrm{m})$ fitted the gap was estimated to be wider than 400 micrometer. This is a very rough estimation and not a very reliable method. The study of Thomas et al. (2007) was an in situ study with its limitations compared to in vivo studies and included only a small number of volunteers $(n=8)$. Besides, the given gap width of 225 micrometer was an average and ranged from 80 to 560 micrometer.

\section{Restorative materials and secondary caries}

An unsolved issue on secondary caries is the influence of material properties on secondary caries formation. The presence of the restorative material may promote or reduce the caries process in several ways. Caries can be promoted as the local lack of dissolution of mineral and the resulting buffering causes the cariogenicity of the biofilm to increase. On the other hand caries may be reduced by materials that release caries preventive substances. Glasionomer cement, for instance, releases fluoride which enhances remineralization. Caries development can also be reduced through inhibition of bacterial growth by the bacteriostatic properties of materials. Amalgam, for instance, releases cariostatic agents, such as $\mathrm{Ag}, \mathrm{Cu}$ and $\mathrm{Zn}$ ions (Nunez et al., 1976; Orstavik, 1985; Morrier et al., 1998).

Restorative materials differ in their bacterial retention by their surface texture. Surface texture plays an important role in early colonization of bacteria on intra-oral surfaces. It has been reported that composite and ceramic materials show thicker biofilms than glassionomers (de Fucio et al., 2009). Besides surface texture there might also be an influence of the restorative material itself on the cariogenicity of the biofilm. In vivo plaque studies have shown that levels of cariogenic bacteria in the plaque present on restorations surfaces are significantly higher on resin composite restorations than on either amalgam or glass ionomer (Svanberg et al., 1990; Hansel et al., 1998; Zalkind et al., 1998). 
Amalgam does not form an adhesive bond to the tooth but forms corrosion products which are assumed to seal the gap between tooth and restoration. Composite restorations bond to tooth tissues, but this does not seem to lead to longer life expectancy of composite restorations. Clinically, failure of composite is mainly associated with secondary caries (Bernardo et al., 2007; Soncini et al., 2007; Opdam et al., 2010;). Clinicians in the USA are still very cautious to restore caries lesions with composite, as they think that the adhesive-dentin interface is still the weak link in composite restorations. Especially with large restorations with margins ending in dentin they prefer amalgam over composite (Shenoy, 2008; Spencer et al., 2010).

\section{Possible influence of loading on secondary caries (hydrodynamic flow)}

Clinically rapid caries progression is often seen in cases where a fixed prosthesis has become detached from one of its abutment teeth. The following clinical example may illustrate a case of secondary caries development in a tooth with a fractured cusp. In Figure 1.2 an amalgam restoration with a clinically good margin is seen. When the amalgam restoration was removed (due to the diagnosis of 'cracked tooth syndrome'), a wall lesion in the cuspal wall was observed. As the primary amalgam restoration had been placed due to primary caries in the approximal surface, it is unlikely that this wall lesion was residual caries. If (residual) caries was left behind when the amalgam restoration was made, it would rather have been located at the axial wall to protect the pulp, not at the cuspal wall. If this wall lesion constituted true secondary caries (that had developed without the presence of a large gap), an interaction between microleakage and loading of the restoration/tooth might be the cause. We hypothesized that the presence of the incomplete fracture would cause an increased mobility of the cusp, leading to opening and closing forces of the gap/fracture line. This movement of the cusp may cause a fluid movement into (at gap opening) and out of (at gap closure) the gap. This fluid movement caused by loading we call hydrodynamic flow. This hydrodynamic flow theory is also applicable to mobile/ debonded restorations.

What is the relation of this hydrodynamic flow with secondary caries? Demineralization of a tooth surface is associated with several diffusion and reaction processes. The rate limiting step of demineralization in a confined area (as in the gap at the interface of a detached restoration) is the diffusion of dissolution products away from the demineralizing tooth surface (Ruben et al., 1999; Bollet-Quivogne et al., 2005). It takes time for acids to penetrate the gap and cause demineralization. However, the role of diffusion can be reduced by agitating the fluid with dissolution products. We think that hydrodynamic flow may assist removal of the dissolution products out of the gap and therefore allowing secondary caries to progress faster. 

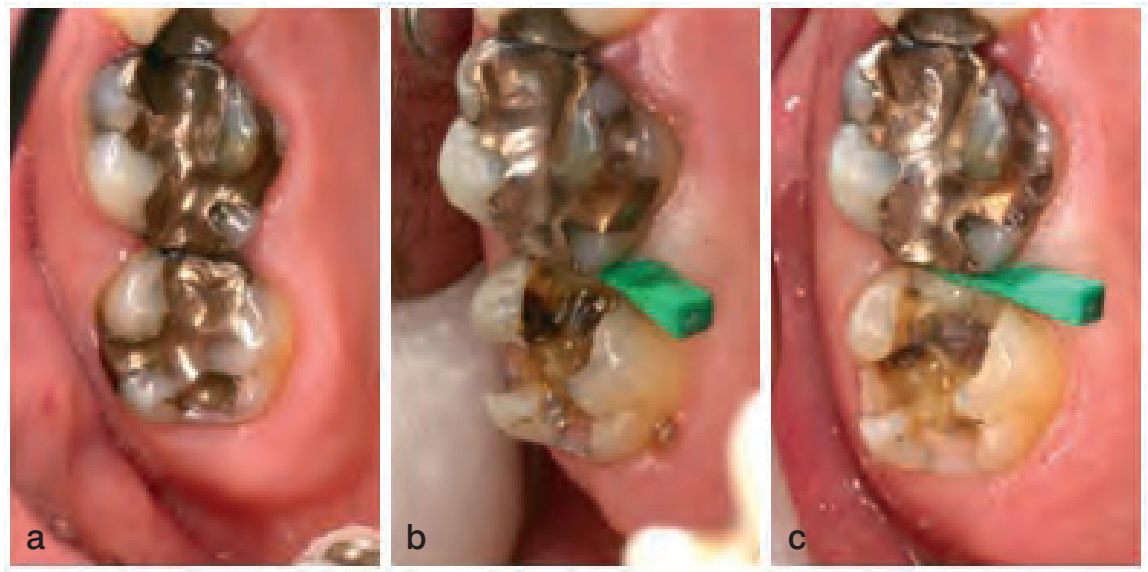

Figure 1.2 Clinical example of tooth with amalgam restoration with clinically good margin (a), upon restoration removal showing a wall lesion at the mesiobuccal cusp (b) and after carious dentine removal an incomplete fracture at the base of that cusp (c). Courtesy of dr. N.J.M. Opdam

\section{Caries models}

The nature of the caries process is very complex and hard to simulate. There are a variety of model systems available that can be applied to study the caries process. We can distinguish between in vitro and in situ and in vivo clinical models, each one presenting advantages and disadvantages.

In vitro caries models are carried out in the laboratory and can be either non-bacterial or bacterial. Non-bacterial models are chemical models in which $\mathrm{pH}$ cycling and immersion in acid medium belong to the possibilities. As lactic acid is the predominant fermentation product of S. Mutans, it is usually used as the demineralization solution in non-bacterial models. The disadvantage of these models is that they are not suited to study bacterial biofilm related factors due to the absence of micro-organisms, consequently, concentrating only on the physical-chemical aspects of tooth substrate dissolution (Holly and Gray, 1968). Another way of investigating the forming of carious lesions in vitro, involves bacterial models in which either planktonic bacteria or micro-organisms organized in biofilms can be used. Planktonic microbial communities exist of single-cells that may float or swim in conventional liquid media. However, as dental caries is a bacterial disease and the bacteria that cause it are growing in biofilms, an in vitro model that uses bacterial biofilms is likely to be more representative than chemical or bacterial slurry systems (Aldsworth and MacFarlane, 2001). 
In vitro studies have greatly improved our understanding of the caries process and the possible underlying mechanisms, however, the in vivo situation is complicated by dietary eating habits, the presence of physiologically secreted saliva, plaque of varying composition and thickness, and a pellicle coated tooth surface (Zero, 1995). Investigation of dental caries clinically is very difficult and cannot be caused on purpose in volunteers as this is ethically unacceptable due to the irreversible dental tissue loss. Clinical caries trials require years to establish significant outcomes and it is hard to standardize conditions.

In situ models serve as bridges between the natural uncontrolled clinical situation and the highly controlled laboratory situation. They involve the use of appliances or other devices which create defined conditions in the human mouth that simulate the process of dental caries (Zero, 1995). Standardized, pre-prepared enamel or dentin samples can be tested within the real oral environment. In situ samples are usually placed in removable appliances, like a palatal device in dentulous volunteers or a prosthesis in edentulous volunteers. Therefore, when the samples are exposed to sucrose attacks, the device with the samples can be removed from the mouth and the dentition of the volunteer will not suffer any damage.

\section{Aim of the $\mathrm{PhD}$ research}

Secondary caries development can be influenced by many factors: restorative or adhesive material used, loading of the restoration, micro- or macroleakage and width of the gap. The extent to which each of these factors contribute to secondary caries attack is undetermined, as is the possible interaction between them. Without this knowledge, it is impossible to establish rational clinical prevention against secondary caries or to understand fully the etiology of secondary caries.

The overall aim of this thesis was to study the influence of gaps and their size on the development of secondary caries.

Other aims of this thesis were:

1) Investigate clinically whether restorations with extending margins below the CEJ, and thus probably exposed to more microleakage, fail more often due to secondary caries (Chapter 2)

2) Study secondary caries development in gaps next to different restorative materials in vitro (Chapter 3) and in situ (Chapter 4)

3) Investigate the relationship between gap-width and wall lesions in situ (Chapter 5)

4) Study secondary caries development at the interface of restorations that were loaded in vitro (Chapter 6) 


\section{References}

Aldsworth TG, MacFarlane TW (2001). A novel in vitro model system to grow films of oral bacteria for the study of human tooth root surface caries. Journal of applied microbiology 91(1):139-146.

Bernardo M, Luis H, Martin MD, Leroux BG, Rue T, Leitao J et al. (2007). Survival and reasons for failure of amalgam versus composite posterior restorations placed in a randomized clinical trial. Journal of the American Dental Association 138(6):775-783.

Bollet-Quivogne FR, Anderson P, Dowker SE, Elliott JC (2005). Scanning microradiographic study on the influence of diffusion in the external liquid on the rate of demineralization in hydroxyapatite aggregates. European journal of oral sciences 113(1):53-59.

Cenci MS, Pereira-Cenci T, Cury JA, Ten Cate JM (2009). Relationship between gap size and dentine secondary caries formation assessed in a microcosm biofilm model. Caries research 43(2):97-102.

de Fucio SB, Puppin-Rontani RM, de Carvalho FG, Mattos-Graner Rde O, Correr-Sobrinho L, Garcia-Godoy F (2009). Analyses of biofilms accumulated on dental restorative materials. American journal of dentistry 22(3):131-136.

Dérand T, Birkhed D, Edwardsson S (1991). Secondary caries related to various marginal gaps around amalgam restorations in vitro. Swedish dental journal 15(3):133-138

Goldberg J, Tanzer J, Munster E, Amara J, Thal F, Birkhed D (1981). Cross-sectional clinical evaluation of recurrent enamel caries, restoration of marginal integrity, and oral hygiene status. Journal of the American Dental Association 102(5):635-641.

Hals E, Nernaes A (1971). Histopathology of in vitro caries developing around silver amalgam fillings. Caries research 5(1):58-77.

Hansel C, Leyhausen G, Mai UE, Geurtsen W (1998). Effects of various resin composite (co)monomers and extracts on two caries-associated micro-organisms in vitro. Journal of dental research 77(1):60-67.

Heintze SD (2007). Systematic reviews: I. The correlation between laboratory tests on marginal quality and bond strength. II. The correlation between marginal quality and clinical outcome. The journal of adhesive dentistry 9 Suppl 1(77-106

Hodges DJ, Mangum FI, Ward MT (1995). Relationship between gap width and recurrent dental caries beneath occlusal margins of amalgam restorations. Community dentistry and oral epidemiology 23(4):200-204.

Holly FJ, Gray JA (1968). Mechanism for incipient carious lesion growth utilizing a physical model based on diffusion concepts. Archives of oral biology 13(3):319-334.

Imazato S (2009). Bio-active restorative materials with antibacterial effects: new dimension of innovation in restorative dentistry. Dental materials journal 28(1):11-19

Jørgensen KD, Wakumoto S (1968). Occlusal amalgam fillings: marginal defects and secondary caries. Odontologisk tidskrift 76(1):43-54

Kidd EA, Joyston-Bechal S, Beighton D (1995). Marginal ditching and staining as a predictor of secondary caries around amalgam restorations: a clinical and microbiological study. Journal of dental research 74(5):1206-1211.

Kidd EA, Fejerskov O (2004). What constitutes dental caries? Histopathology of carious enamel and dentin related to the action of cariogenic biofilms. Journal of dental research $83 \mathrm{Spec}$ No C(C35-38.

Mjör IA (2005). Clinical diagnosis of recurrent caries. Journal of the American Dental Association 136(10):14261433.

Morrier JJ, Suchett-Kaye G, Nguyen D, Rocca JP, Blanc-Benon J, Barsotti O (1998). Antimicrobial activity of amalgams, alloys and their elements and phases. Dental materials : official publication of the Academy of Dental Materials 14(2):150-157.

Nunez LJ, Schmalz G, Hembree J (1976). Influence of amalgam, alloy, and mercury on the in vitro growth of Streptococcus mutans: I. Biological test system. Journal of dental research 55(2):257-261.

Opdam NJ, Bronkhorst EM, Roeters JM, Loomans BA (2007). A retrospective clinical study on longevity of posterior composite and amalgam restorations. Dental materials : official publication of the Academy of Dental Materials 23(1):2-8.

Opdam NJ, Bronkhorst EM, Loomans BA, Huysmans MC (2010). 12-year survival of composite vs. amalgam restorations. Journal of dental research 89(10):1063-1067. 
Orstavik D (1985). Antibacterial properties of and element release from some dental amalgams. Acta odontologica Scandinavica 43(4):231-239.

Ruben J, Arends J, Christoffersen J (1999). The effect of window width on the demineralization of human dentine and enamel. Caries research 33(3):214-219

Sarrett DC (2005). Clinical challenges and the relevance of materials testing for posterior composite restorations. Dental materials : official publication of the Academy of Dental Materials 21(1):9-20.

Shenoy A (2008). Is it the end of the road for dental amalgam? A critical review. Journal of conservative dentistry : JCD 11(3):99-107.

Soncini JA, Maserejian NN, Trachtenberg F, Tavares M, Hayes C (2007). The longevity of amalgam versus compomer/composite restorations in posterior primary and permanent teeth: findings From the New England Children's Amalgam Trial. Journal of the American Dental Association 138(6):763-772.

Spencer P, Ye Q, Park J, Topp EM, Misra A, Marangos O et al. (2010). Adhesive/Dentin interface: the weak link in the composite restoration. Annals of biomedical engineering 38(6):1989-2003.

Svanberg M, Mjor IA, Orstavik D (1990). Mutans streptococci in plaque from margins of amalgam, composite, and glass-ionomer restorations. Journal of dental research 69(3):861-864.

Thomas RZ, Ruben JL, ten Bosch JJ, Fidler V, Huysmans MC (2007). Approximal secondary caries lesion progression, a 20-week in situ study. Caries research 41(5):399-405.

Totiam P, Gonzalez-Cabezas C, Fontana MR, Zero DT (2007). A new in vitro model to study the relationship of gap size and secondary caries. Caries research 41(6):467-473.

Zalkind MM, Keisar O, Ever-Hadani P, Grinberg R, Sela MN (1998). Accumulation of Streptococcus mutans on light-cured composites and amalgam: an in vitro study. Journal of esthetic dentistry 10(4):187-190.

Zero DT (1995). In situ caries models. Advances in dental research 9(3):214-230; discussion 231-214. 



\title{
2
}

\section{The influence of approximal restoration extension on the development of secondary caries}

\author{
NK Kuper \\ NJM Opdam \\ EM Bronkhorst \\ MCDNJM Huysmans
}

Department of Preventive and Restorative Dentistry,

Radboud University Medical Centre, Nijmegen, the Netherlands

Journal of Dentistry 2012; 40(3):241-247 


\section{Abstract}

Objectives: To evaluate whether occlusoproximal restorations with cervical margins apical to the cemento-enamel junction (CEJ) are more prone to failure than restorations with margins coronal to the CEJ, in particular failure due to secondary caries.

Methods: A method was developed for scoring cervical margin extension on bitewings, and validated in vitro. Records from patients with at least one occlusoproximal restoration replaced due to secondary caries were selected from an existing database. Cervical margins of approximal restoration sites were scored on bitewings in relation to the CEJ (supra vs. sub CEJ). For all restorations dates of placement, replacement and reason for failure were recorded. Survival times were calculated and Cox-regression analysis was applied to assess influence of selected variables on survival of restorations: extension of cervical margins, number of restored surfaces, restoration material and age of the patient.

Results: Records of 84 patients with 1912 restoration sites were examined, 655 failed; 399 supra CEJ and 256 sub CEJ. 257 restorations failed because of secondary caries. Restorations ending below the CEJ showed significantly increased risk for failure $(H R=1.28, p=0.020)$, however, no relation with secondary caries was found $(p=0.130)$. Amalgam restorations showed decreased risk for secondary caries $(H R$ $=0.51, p<0.001)$

Conclusion: Occlusoproximal restorations with cervical margins apical to the CEJ do not fail more often due to secondary caries. However, those restorations did show larger risk of failure overall compared to restorations with margins coronal to the CEJ. Resin composite restorations showed increased risk for secondary caries compared to amalgam restorations.

Clinical significance: Within the limitations of this study, no association was found clinically between extension of restoration margins below the CEJ and the occurrence of secondary caries. 


\section{Introduction}

Occlusoproximal restorations have their cervical margins located either above or below the CEJ. The location of the cervical margin is considered to be relevant for the clinical performance of those restorations. It is generally recommended that, if possible, the cervical margin of restorations should be located in intact enamel (Hilton et al., 1997; Ferrari et al., 1999; Summit et al., 2006; Kenyon et al., 2007). Those recommendations are based on the results of several in vitro studies, which demonstrate more microleakage when restorations have margins apical to the CEJ (Retief et al., 1992; Hasanreisoglu et al., 1996; Wibowo and Stockton, 2001; Brunton et al., 2004; Araujo et al., 2006; da Silva et al., 2006; Campos et al., 2008; Rodrigues Junior et al., 2010). In these in vitro studies it is often claimed that microleakage is a predisposing factor in the development of secondary caries (Kidd, 1976; Eriksen and Pears, 1978; Campos et al., 2008) and therefore restorations with cervical margins below the CEJ are considered to have an increased risk for clinical failure due to secondary caries (Hilton et al., 1997; Summit et al., 2006; Campos et al., 2008).

Developments in cariology have put the relevance of microleakage into question, as secondary caries could only be found clinically in conjunction with large gaps (Kidd et al., 1995; Özer, 1997; Thomas et al., 2007) and in the presence of an active biofilm, leading to the statement by Mjör (2005) that 'macroleakage' instead of microleakage is necessary to induce caries in the tooth-restoration interface. Moreover, a review study could not demonstrate any correlation between microleakage as found in vitro for certain types of restorations and the clinical performance of the same type of restorations (Heintze, 2007).

This study aimed to evaluate whether occlusoproximal restorations with cervical margins apical to the CEJ are more prone to failure than restorations with margins coronal to the CEJ, in particular in respect of failure due to secondary caries.

\section{Materials and Methods}

\section{Retrospective clinical study}

An existing database (Opdam et al., 2010) with patient files of a Dutch general dental practice, was used for collecting data for this study. Design and protocol were approved by the local ethics committee METC (CMO file nr. 2008/150). Included in this study were all patients who visited the practice for a check-up visit between May and November 2008 and already had attended the practice for routine check-up visits for at least 5 years. Furthermore, the selected patients needed to have had one or more occlusoproximal restorations replaced due to secondary caries at the approximal site. Another prerequisite for inclusion was the presence of bitewing 
radiographs in the records for caries diagnosis and monitoring the status of approximal surfaces of the patient during the observation period.

The selected patient files were reassessed and data were collected on all resin composite and amalgam occlusoproximal restorations placed between 1983 (practice opened) and 2003 (inclusion limit, allowing for a minimum of 5 years follow-up). Date of restoration-placement and last check-up visit were recorded. Date and reason for failure were also recorded.

A restoration was considered as failed whenever the restoration was:

- replaced

- repaired

- scheduled for replacement

- extracted

A restoration was considered successful whenever the restoration was:

- still in function at the last check-up

- clinically acceptable

A restoration was not considered as failed, but the observation period was censored whenever:

- a crown was placed, not related to a direct restoration failure

- a complete restoration with two sites (mesial and distal) was replaced, due to failure at one site. In those cases, the restoration site showing no failure was censored.

Within each patient it was possible that a single tooth yielded more than one restoration, as replacements during the 20 years of observation were also taken into account.

For assessment of secondary caries, the location of all cervical margins of the restorations in relation to the CEJ were scored on the first available bitewing after restoration placement. A five-point ordinal rating scale was used, indicating the extension of the margins (see Figures 2.1 and 2.2):

- Score 0: cervical outline coronal to the CEJ, leaving a clear amount of enamel visible

- Score 1: cervical outline coronal to the CEJ, leaving a small ridge of enamel visible

- Score 2: cervical outline at the level of the CEJ, leaving no enamel visible

- Score 3: cervical outline just apical to the CEJ

- Score 4: cervical outline well apical to the CEJ

For the statistical analysis this scale was collapsed to a dichotomous scale with two categories supra CEJ (scores 0 and 1) and sub CEJ (scores 2,3 and 4).

MOD-restorations were scored twice, as mesial and distal surfaces were evaluated as an individual site. If a complete restoration with two sites (mesial and distal) was 


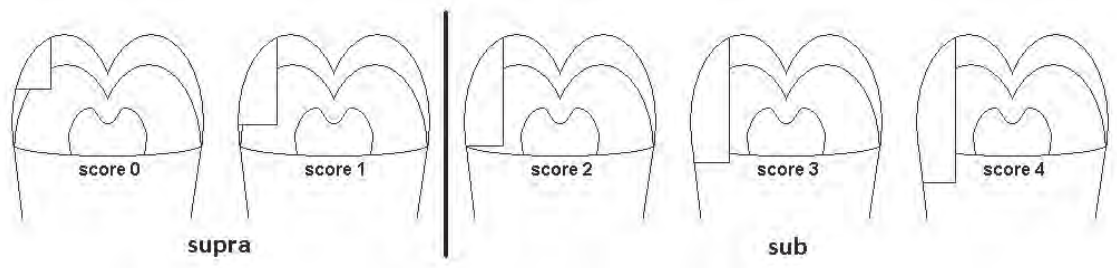

Figure 2.1 Five point scale used for scoring the cervical extension of restoration margins
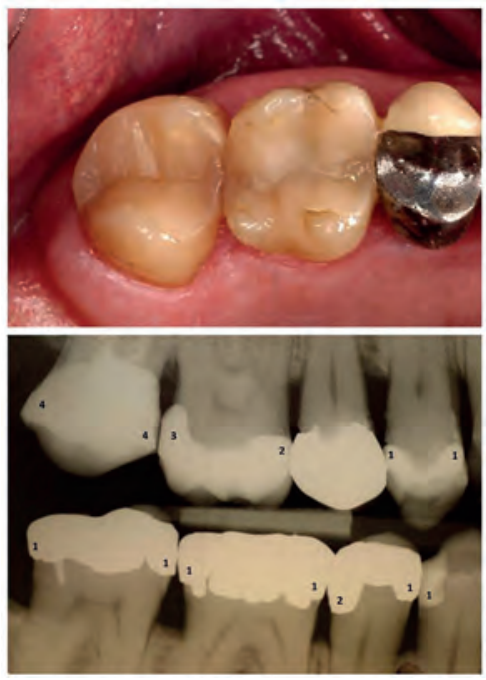

Figure 2.2 Clinical photograph of a large, successful composite resin restoration below the CEJ in tooth 17. Bitewing radiograph of the same restoration with scores of all restoration sites

replaced, due to failure at one site, the restoration site showing no failure was assigned 're-restoration' and censored.

Survival times of the restorations were computed and a Cox-regression (Opdam et al., 2011) was applied to assess the influence on survival of the restorations of the selected variables extension of cervical margins, number of restored surfaces, restoration material and age of the patient. Since multiple restorations per patient could be included in the analysis, the Cox-regression model was extended with a gamma frailty term to model this clustering of data (Andersen et al., 1997). The 
statistical package R, version 2.10.1, was used for statistical analysis (R Development Core Team, 2009). The level of significance was set at $p<0.05$.

\section{Validation of scoring method}

A pilot was carried out to assess if the location of restoration margins could be scored reproducibly and correctly on bitewing radiographs. 35 human extracted (pre)molars with 58 approximal restoration sites (29 amalgam and 29 resin composite) were selected. The selection of teeth was based on direct visual assessment in order to achieve per material equal proportions of three different categories of restorations with cervical margins either coronal to $(n=10)$, apical to $(n=10)$ or crossing $(n=9)$ the CEJ (meaning that part of the margin was coronal and that part of was apical to the CEJ).

The teeth were mounted in artificial jaws to simulate clinical circumstances, and bitewing radiographs were exposed using paralleling technique (F-speed film, 15 $\mathrm{mA}, 70 \mathrm{kV}, 0.3 \mathrm{~s}$, target-focus distance $10.5 \mathrm{~cm}$ ). The bitewings were developed with an automatic $\mathrm{X}$-ray processor (Periomat, Dürr Dental)

Four dental faculty members served as observers, including the main investigator (NK). The observers assessed the extension of all cervical margins using the same five-point rating scale as mentioned above (Figure 2.1). For validation, classification of the visual assessment was used as gold standard. Scores 0 and 1 were considered to be correct if the gold standard defined the restoration margin as coronal to the CEJ. Scores 2,3 and 4 were considered to be correct if the gold standard defined the restoration margin as crossing the CEJ or apical to the CEJ. The main investigator scored the extension of cervical margins twice with two months between consecutive sessions.

Cohen's kappa was computed for intra- and inter-examiner agreement. The visual examination and the main investigator scores were used to compute the sensitivity and specificity. 


\section{Results}

\section{Validation of scoring method}

Table 2.1 shows the cross-tabulated scores of the visual assessment with the bitewing scores of the main investigator. Using the dichotomized scale, sensitivity was $85 \%$, specificity was $94 \%$ and the percentage correct was $91 \%$.

The intra-examiner kappa value for the main investigator was 1.00 and interexaminer kappa values between the four observers varied between 0.69 and 0.96 indicating a high reliability of the method.

Table 2.1 Results of the in vitro validation procedure. Bitewings scores crosstabulated with direct visual assessment scores. The threshold for the dichotomized scale is shown in double lines

\begin{tabular}{|c|c|c|c|c|c|c|c|}
\hline & & \multicolumn{5}{|c|}{ Score BW } & \multirow[b]{2}{*}{ Total } \\
\hline & & 0 & 1 & 2 & 3 & 4 & \\
\hline \multirow{4}{*}{$\begin{array}{l}\text { Score } \\
\text { visual }\end{array}$} & Coronal & 8 & 9 & 3 & 0 & 0 & 20 \\
\hline & Mid & 0 & 2 & 9 & 6 & 1 & 18 \\
\hline & Apical & 0 & 0 & 0 & 4 & 16 & 20 \\
\hline & Total & 8 & 11 & 12 & 10 & 17 & 58 \\
\hline
\end{tabular}

\section{Retrospective clinical study}

Records of 84 patients with 877 restored teeth $($ minimum $=4$, median $=10.5$, maximum $=16)$ and 1193 restorations $($ minimum $=4$, median $=14$, maximum $=28)$ were evaluated. This resulted in 1912 approximal sites (minimum $=6$, median $=22$, maximum $=53$ ), consisting of 1189 amalgam and 723 resin composite sites. The mean restoration observation period was 13.7 years. The collapsed extension scores were used to divide the restoration sites into a supra- $(n=1191)$ and sub-group $(n=721)$.

In total 655 sites showed failure of the restoration, 399 in the supra-group and 256 in the sub-group. 42 sites were censored due to placement of a crown and 134 sites due to re-restoration.

The reasons for failure are shown in Table 2.2 and some examples of restoration failures are shown in Figures 2.3 and 2.4. The mean observation times were considerably different between amalgam (16.0 years) and resin composite ( 9.9 years). The mean annual failure rates over the first 12 years of each group were: amalgam supra $=1.6 \%$, amalgam sub $=2.3 \%$, resin composite supra $=1.9 \%$, resin composite sub $=2.7 \%$ 
Table 2.2 Overview of the reasons for failure, for all restoration sites, and for the supra CEJ and sub CEJ, and amalgam and composite restorations separately

\begin{tabular}{|c|c|c|c|c|c|c|}
\hline & \multicolumn{4}{|c|}{ Supra } & \multirow{2}{*}{\multicolumn{2}{|c|}{ All supra }} \\
\hline & \multicolumn{2}{|c|}{ Amalgam } & \multicolumn{2}{|c|}{ Composite } & & \\
\hline \multirow{2}{*}{$\begin{array}{c}\text { Mean observation } \\
\text { time }\end{array}$} & \multicolumn{2}{|c|}{16.6 years } & \multicolumn{2}{|c|}{10.3 years } & \multicolumn{2}{|c|}{14.4 years } \\
\hline & $\mathrm{n}$ & $\%$ & $\mathrm{n}$ & $\%$ & $\mathrm{n}$ & $\%$ \\
\hline Clinically acceptable & 448 & $58.0 \%$ & 344 & $82.3 \%$ & 792 & $66,5 \%$ \\
\hline Secondary caries & 115 & $14.9 \%$ & 43 & $10.3 \%$ & 158 & $13,3 \%$ \\
\hline Fracture tooth & 55 & $7.1 \%$ & 3 & $0.7 \%$ & 58 & $4,9 \%$ \\
\hline Fracture restoration & 19 & $2.5 \%$ & 10 & $2.4 \%$ & 29 & $2,4 \%$ \\
\hline Cracked tooth & 53 & $6.9 \%$ & 0 & $0.0 \%$ & 53 & $4,5 \%$ \\
\hline Esthetics & 29 & $3.8 \%$ & 0 & $0.0 \%$ & 29 & $2,4 \%$ \\
\hline Extraction & 7 & $0.9 \%$ & 8 & $1.9 \%$ & 15 & $1,3 \%$ \\
\hline Endo/pain & 12 & $1.6 \%$ & 0 & $0.0 \%$ & 12 & $1,0 \%$ \\
\hline Other & 3 & $0.4 \%$ & 1 & $0.2 \%$ & 4 & $0,3 \%$ \\
\hline Unknown & 32 & $4.1 \%$ & 9 & $2.2 \%$ & 41 & $3,4 \%$ \\
\hline Total & 773 & $100.0 \%$ & 418 & $100.0 \%$ & 1191 & $100,0 \%$ \\
\hline
\end{tabular}

In the Kaplan Meier curve (Figure 2.5) the overall survival rate of each group (amalgam vs. composite and supra vs. sub) is shown.

In Table 2.3 the results of the Cox-regression analysis are shown. For general failure, restoration sites with margins below the CEJ had a larger risk of failure ( $\mathrm{HR}=$ 1.28, $\mathrm{p}=0.020)$, and more restoration surfaces increased the risk for failure $(\mathrm{HR}=$ $1.15, p=0.007$ ). For secondary caries, the Cox-regression revealed the number of surfaces to be significant, with each added surface to a restoration increasing the risk for secondary caries with $27 \%(H R=1.27, p<0.001)$. For the risk of secondary caries, there was no significant difference in restorations with margins sub or supra CEJ $(p=0.130)$. However, restoration material was a significant risk factor, with resin composite restorations showing twice as much secondary caries as amalgam restorations $(\mathrm{HR}=0.51, \mathrm{p}<0.001)$. 


\begin{tabular}{|c|c|c|c|c|c|c|c|}
\hline \multicolumn{4}{|c|}{ Sub } & \multirow{2}{*}{\multicolumn{2}{|c|}{ All sub }} & \multirow{2}{*}{\multicolumn{2}{|c|}{ All }} \\
\hline \multicolumn{2}{|c|}{ Amalgam } & \multicolumn{2}{|c|}{ Composite } & & & & \\
\hline \multicolumn{2}{|c|}{14.9 years } & \multicolumn{2}{|c|}{9.4 years } & \multicolumn{2}{|c|}{12.6 years } & \multicolumn{2}{|c|}{13.7 years } \\
\hline $\mathrm{n}$ & $\%$ & $\mathrm{n}$ & $\%$ & $n$ & $\%$ & $\mathrm{n}$ & $\%$ \\
\hline 232 & $55.8 \%$ & 233 & $76.4 \%$ & 465 & $64,5 \%$ & 1257 & $65.7 \%$ \\
\hline 55 & $13.2 \%$ & 44 & $14.4 \%$ & 99 & $13,7 \%$ & 257 & $13.4 \%$ \\
\hline 27 & $6.5 \%$ & 6 & $2.0 \%$ & 33 & $4,6 \%$ & 91 & $4.8 \%$ \\
\hline 19 & $4.6 \%$ & 8 & $2.6 \%$ & 27 & $3,7 \%$ & 56 & $2.9 \%$ \\
\hline 18 & $4.3 \%$ & 0 & $0.0 \%$ & 18 & $2,5 \%$ & 71 & $3.7 \%$ \\
\hline 10 & $2.4 \%$ & 0 & $0.0 \%$ & 10 & $1,4 \%$ & 39 & $2.0 \%$ \\
\hline 7 & $1.7 \%$ & 10 & $3.3 \%$ & 17 & $2,4 \%$ & 32 & $1.7 \%$ \\
\hline 21 & $5.0 \%$ & 0 & $0.0 \%$ & 21 & $2,9 \%$ & 33 & $1.7 \%$ \\
\hline 4 & $1.0 \%$ & 2 & $0.7 \%$ & 6 & $0,8 \%$ & 10 & $0.5 \%$ \\
\hline 23 & $5.5 \%$ & 2 & $0.7 \%$ & 25 & $3,5 \%$ & 66 & $3.5 \%$ \\
\hline 416 & $100.0 \%$ & 305 & $100.0 \%$ & 721 & $100,0 \%$ & 1912 & $100.0 \%$ \\
\hline
\end{tabular}




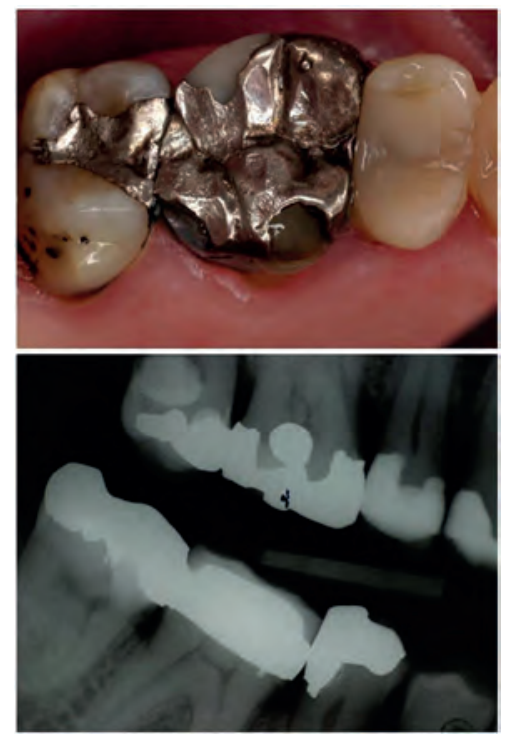

Figure 2.3 Clinical photograph and bitewing radiograph of a large amalgam restoration in tooth 16 , considered as failed due to a fractured cusp
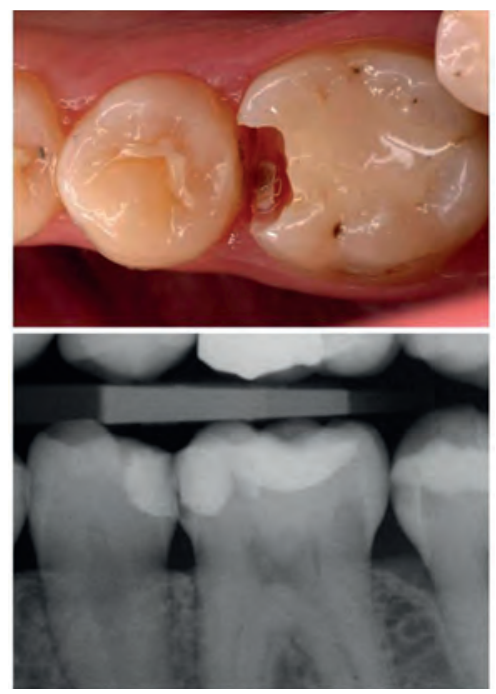

Figure 2.4 Clinical photograph and bitewing radiograph of failing restoration showing secondary caries after removal of composite resin MO-restoration in tooth 36 


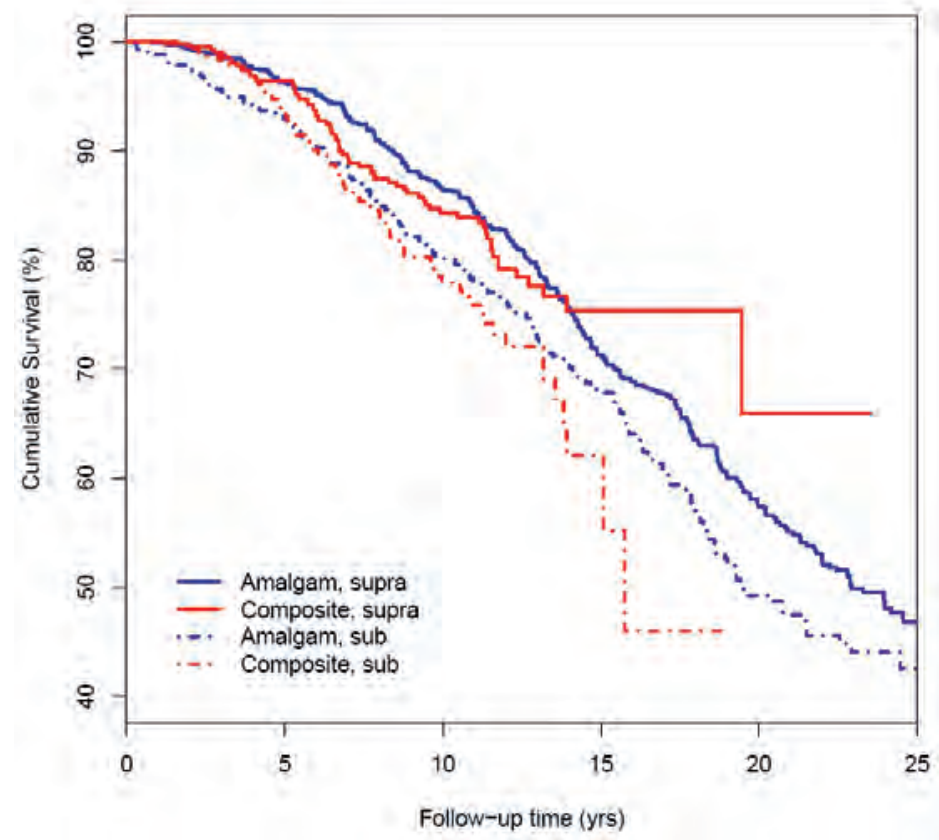

Figure 2.5 Kaplan Meier estimates of overall survival according to the restoration material and cervical margin extension

Table 2.3 Results of the Cox regression analysis

\begin{tabular}{|c|c|c|c|c|c|}
\hline \multirow[t]{2}{*}{$\begin{array}{l}\text { Failure } \\
\text { reason }\end{array}$} & \multirow[t]{2}{*}{ Variable } & \multirow[t]{2}{*}{ p-Value } & \multirow[t]{2}{*}{$\begin{array}{l}\text { Hazard } \\
\text { ratio }\end{array}$} & \multicolumn{2}{|c|}{$\begin{array}{l}95 \% \text { confidence } \\
\text { interval for HR }\end{array}$} \\
\hline & & & & Lower & Upper \\
\hline \multirow{4}{*}{$\begin{array}{l}\text { Failure in } \\
\text { general }\end{array}$} & Extension (supra $=0$, sub $=1$ ) & 0.020 & 1.28 & 1.04 & 1.58 \\
\hline & Nr. surfaces & 0.007 & 1.15 & 1.04 & 1.27 \\
\hline & Material $(\mathrm{comp}=0, \mathrm{am}=1)$ & 0.504 & 0.91 & 0.71 & 1.18 \\
\hline & Age & 0.475 & 0.995 & 0.98 & 1.01 \\
\hline \multirow{4}{*}{$\begin{array}{l}\text { Secondary } \\
\text { caries }\end{array}$} & Extension (supra $=0$, sub $=1$ ) & 0.130 & 1.24 & 0.94 & 1.65 \\
\hline & Nr. surfaces & $<0.001$ & 1.27 & 1.12 & 1.45 \\
\hline & Material $(\mathrm{comp}=0, a m=1)$ & $<0.001$ & 0.51 & 0.38 & 0.68 \\
\hline & Age & 0.078 & 0.982 & 0.96 & 1.00 \\
\hline
\end{tabular}




\section{Discussion}

Within the limitations of this study we found that the cervical extension of restorations was a significant factor for failure in general, however no association between cervical margin extension and secondary caries was observed. For this study, a longitudinal database from a general dental practice was used and bitewing radiographs of restorations were used to assess the approximal margin location as supra or sub CEJ.

Estimating the cervical extension of restorations by scoring the cervical margins in relation to the CEJ on bitewings was not described before. Our validation study establishes that this method meets the requirements of reproducibility and validity. The authors have considered several options to divide the clinical scores of the restorations in different groups with reference to the CEJ, including three categories: supra-, juxta- and sub CEJ. However to increase the statistical power and to guarantee separation between restorations including at least the outline partially located in dentine and the outline in enamel, we only chose two categories: supra- and sub CEJ. We included restorations with score 2 in the sub CEJ-group, as the validation showed that for most of these restorations part of the cervical outline was not ending in enamel. It can be argued the allocation of this borderline group may have influenced the outcome for secondary caries in relation to margin extension. In order to address this uncertainty, another Cox-regression analysis on secondary caries was carried out with placing these restorations in a separate juxta-CEJ group. If we then evaluated the definite supra and definite sub CEJ restorations, an effect of extension of cervical margins became even less likely ( $p=0.265$ and $H R=1.23$ ).

Drawbacks of the scoring method used are that the restoration-margin location in relation to the level of the gingival margin could not be evaluated and that overhang of restorations was not taken into account. It may be assumed that restorations located apical to the CEJ are located subgingivally in patients with a healthy periodontium. However, considering the long observation period (mean 9.4-16.6 years, depending on the restoration group) and depending on the patients age, gingival margin location may well have changed, unlike the restoration extension in relation to the CEJ, which is stable. Therefore, no conclusion can be made regarding the influence of gingival margin location. Clinical factors that are related to the level of the gingiva, such as the assumption that restorations placed subgingivally have a poorer prognosis due to difficulties in moisture control or differences in caries susceptibility of tooth surfaces below or above the gingiva, cannot be discussed.

The study was done in the practice of one of the authors, who did his best to deliver high quality restorative work. This included the use of three step etch and rinse systems and hybrid composites in almost all cases, which nowadays are still considered as gold standard materials. It is stated that overhang can cause more 
plaque accumulation and therefore more caries. Very few obvious overhangs could be detected radiographically. Even assuming that minor overhangs may still have been present, it is likely that restorations ending sub CEJ exhibit more overhang whereas no increased risk for secondary caries for restorations sub CEJ was found.

In the practice investigated, before 1994 almost all large occlusoproximal cavities were restored with amalgam, whereas after 1995 no amalgam restorations were made anymore. This implicates that the choice of restoration material used, was dependent upon the time period and not on cavity design unlike other studies (Lubisich et al., 2011). The two operators in this practice had a conservative approach towards caries treatment. Restoration of primary or secondary caries was only carried out when frank cavitation or lesion progression following bitewing radiographs was observed.

For this study the same group of patients was used as in Opdam et al. (2010), however, the restoration sample used has only limited overlap. In the previous report only large restorations with three or more surfaces were included. In this study, patients were excluded that had no restorations failing due to secondary caries. Moreover, all restorations of selected patients were reassessed including also smaller occlusoproximal restorations. Additionally, MOD restorations were split into two sites in order to take into account differences of cervical extension that could be present at the different restoration sites. There is an intentional selection bias in the present database due to selection of patients with secondary caries. Therefore, it can be assumed that a considerable number of high risk patients were included in the study, which is confirmed by the high percentage of failure due to secondary caries (257/655 $=39 \%$ ) within the failures.

It is appealing to analyse other failure reasons from this database, for example failure due to fracture, extraction or endodontic treatment. However, we chose to analyse only failure in general and secondary caries, as those failure groups showed the largest numbers. Any attempts to analyse the other failure reasons, resulted in too small numbers, overfitting and violation of the proportional hazard assumption. Also, as this was a selected high caries risk group, other failure reasons than caries could not be generalized.

In the Cox-regression analysis the variable gender was not included, as this variable violated the assumption of proportional hazards in the analysis of failure in general. However, omitting this significant variable altered the p-values and hazards ratios of the other variables (extension, number of surfaces, material and age) only marginally. The analysis showed that for sub CEJ margins of restorations failure in general increased. As one can assume that in the group sub CEJ more extended restorations were included, this might be explained by increased risk for problems when restorations come closer to the pulp (Murray et al., 2003) and extend deep subgingivally, as expressed in higher failures due to endodontic problems or 
extractions (Table 2.2). The increase in the number of restored surfaces as a negative factor for longevity was expected (Van Nieuwenhuysen et al., 2003; da Rosa Rodolpho et al., 2006; Opdam et al., 2007).

The present study had two major outcomes. First, no association could be found between the extension of cervical margins of restorations and the prevalence of secondary caries. This is consistent with the review study of Heintze (2007) which could not demonstrate any correlation either between microleakage of the restoration in vitro and clinical performance. Therefore, the relevance of microleakage studies as often done in vitro, should be questioned, when it comes to the often assumed relation between microleakage and secondary caries. As it can be assumed that the restorations in this clinical study having cervical margins below the CEJ had more cervical microleakage, this has in fact not lead to more secondary caries. The authors want to emphasize that microleakage studies in vitro may be very useful for screening the properties of new materials and to explain differences as found clinically. Moreover in the present study, microleakage may have caused bacterial invasion of the gap resulting in the pulpal problems as found.

The second major outcome of this study is that secondary caries as a reason for failure was relatively more frequent with resin composite than with amalgam restorations. This is in agreement with studies of Bernardo et al. (2007) and Soncini et al. (2007) who found that there was a higher prevalence of secondary caries next to resin composite restorations. In those studies children were used as subjects, and in that group relatively more high risk patients will be present, as is the case with the present study. An explanation often mentioned for this is that composite is a much more technique-sensitive material to place. However, if we assume that the restorations with a more apical extension are more difficult to place, as isolation and matrix placement are more complicated, the absence of an effect of margin extension on secondary caries does not support the role of operator technique. Further research should focus on the influence of material properties on secondary caries.

The conclusion of this study is that restorations ending sub CEJ have increased risk for failure. However, secondary caries is not more present with restorations with margins below the CEJ. The outcome of the study also shows a higher risk for secondary caries related to composite resin restorations. To the opinion of the authors this does not mean that amalgam restorations are superior to resin composite restorations when it comes to restoring occlusoproximal restorations. Within the limitations of the present study, conducted in a considerable high risk population, general failure is not material dependant, only the secondary caries risk is higher for composite. This is compensated by a lower failure on other aspects, which could not be retrieved from the data on a statistically significant way. However, based on the same practice population without the applied inclusion of high risk patients, even a significantly better performance of large occlusoproximal composite resin restorations 
was found, especially in the low risk group, including $80 \%$ of the patients (Opdam et al., 2010). So, in most, if not all cases, a posterior composite resin restoration might be the better choice compared to an amalgam.

\section{Acknowledgement}

The study was supported by the authors' institution. 


\section{References}

Andersen PK, Klein JP, Knudsen KM, Tabanera y Palacios R (1997). Estimation of variance in Cox's regression model with shared gamma frailties. Biometrics 53(4):1475-1484.

Araujo FO, Vieira LC, Monteiro Junior S (2006). Influence of resin composite shade and location of the gingival margin on the microleakage of posterior restorations. Operative dentistry 31(5):556-561.

Bernardo M, Luis H, Martin MD, Leroux BG, Rue T, Leitao J et al. (2007). Survival and reasons for failure of amalgam versus composite posterior restorations placed in a randomized clinical trial. Journal of the American Dental Association 138(6):775-783.

Brunton PA, Kassir A, Dashti M, Setcos JC (2004). Effect of different application and polymerization techniques on the microleakage of proximal resin composite restorations in vitro. Operative dentistry 29(1):54-59.

Campos PE, Barceleiro Mde O, Sampaio-Filho HR, Martins LR (2008). Evaluation of the cervical integrity during occlusal loading of Class II restorations. Operative dentistry 33(1):59-64.

da Rosa Rodolpho PA, Cenci MS, Donassollo TA, Loguercio AD, Demarco FF (2006). A clinical evaluation of posterior composite restorations: 17-year findings. Journal of dentistry 34(7):427-435.

da Silva AF, Piva E, Demarco FF, Correr Sobrinho L, Osinga PW (2006). Microleakage in conventional and bonded amalgam restorations: influence of cavity volume. Operative dentistry 31(3):377-383.

Eriksen HM, Pears G (1978). In vitro caries related to marginal leakage around composite resin restorations. Journal of oral rehabilitation 5(1):15-20.

Ferrari M, Mannocci F, Kugel G, Garcia-Godoy F (1999). Standardized microscopic evaluation of the bonding mechanism of NRC/Prime \& Bond NT. American journal of dentistry 12(2):77-83.

Hasanreisoglu U, Sonmez H, Uctasli S, Wilson HJ (1996). Microleakage of direct and indirect inlay/onlay systems. Journal of oral rehabilitation 23(1):66-71.

Heintze SD (2007). Systematic reviews: I. The correlation between laboratory tests on marginal quality and bond strength. II. The correlation between marginal quality and clinical outcome. The journal of adhesive dentistry 9 Suppl 1(77-106.

Hilton TJ, Schwartz RS, Ferracane JL (1997). Microleakage of four Class II resin composite insertion techniques at intraoral temperature. Quintessence international 28(2):135-144.

Kenyon BJ, Frederickson D, Hagge MS (2007). Gingival seal of deep Class II direct and indirect composite restorations. American journal of dentistry 20(1):3-6.

Kidd EA (1976). Microleakage: a review. Journal of dentistry 4(5):199-206.

Kidd EA, Joyston-Bechal S, Beighton D (1995). Marginal ditching and staining as a predictor of secondary caries around amalgam restorations: a clinical and microbiological study. Journal of dental research 74(5):1206-1211.

Lubisich EB, Hilton TJ, Ferracane JL, Pashova HI, Burton B, Northwest P (2011). Association between caries location and restorative material treatment provided. Journal of dentistry 39(4):302-308.

Mjör IA (2005). Clinical diagnosis of recurrent caries. Journal of the American Dental Association 136(10):1426-1433.

Murray PE, Smith AJ, Windsor LJ, Mjor IA (2003). Remaining dentine thickness and human pulp responses. International endodontic journal 36(1):33-43.

Opdam NJ, Bronkhorst EM, Roeters JM, Loomans BA (2007). Longevity and reasons for failure of sandwich and total-etch posterior composite resin restorations. The journal of adhesive dentistry 9(5):469-475.

Opdam NJ, Bronkhorst EM, Loomans BA, Huysmans MC (2010). 12-year survival of composite vs. amalgam restorations. Journal of dental research 89(10):1063-1067.

Opdam NJ, Bronkhorst EM, Cenci MS, Huysmans MC, Wilson NH (2011). Age of failed restorations: A deceptive longevity parameter. Journal of dentistry 39(3):225-230.

Özer $L$ (1997). The relationship between gap size, microbial accumulation and the structural features of natural caries in extracted teeth with class II amalgam restorations. Thesis/Dissertation. University of Copenhagen.

R Development Core Team (2009). R: a language and environment for statistical computing. Vienna, Austria: R Foundation for Statistical Computing. ISBN 3-900051-07-0, URL http://www.R-project.org. 
Retief DH, McCaghren RA, Russell CM (1992). Microleakage of Vitrebond/P-50 Class II restorations. American journal of dentistry 5(3):130-132.

Rodrigues Junior SA, Pin LF, Machado G, Della Bona A, Demarco FF (2010). Influence of different restorative techniques on marginal seal of class II composite restorations. Journal of applied oral science : revista FOB 18(1):37-43.

Soncini JA, Maserejian NN, Trachtenberg F, Tavares M, Hayes C (2007). The longevity of amalgam versus compomer/composite restorations in posterior primary and permanent teeth: findings From the New England Children's Amalgam Trial. Journal of the American Dental Association 138(6):763-772.

Summit JB, Williams Robins J, Hilton TJ, Swartz RS (2006). Fundamentals of operative dentistry: a contemporary approach. Quintessence Publishing Co Inc.

Thomas RZ, Ruben JL, ten Bosch JJ, Fidler V, Huysmans MC (2007). Approximal secondary caries lesion progression, a 20-week in situ study. Caries research 41(5):399-405.

Van Nieuwenhuysen JP, D'Hoore W, Carvalho J, Qvist V (2003). Long-term evaluation of extensive restorations in permanent teeth. Journal of dentistry 31(6):395-405.

Wibowo G, Stockton L (2001). Microleakage of Class II composite restorations. American journal of dentistry 14(3):177-185 



\title{
Restoration materials and secondary caries using an in vitro biofilm model
}

\author{
NK Kuper ${ }^{1 \star}$ \\ FH van de Sande ${ }^{2 \star}$ \\ NJM Opdam \\ EM Bronkhorst ${ }^{1}$ \\ $\mathrm{JJ}$ de Soet ${ }^{3}$ \\ MS Cenci ${ }^{2}$ \\ MCDNJM Huysmans ${ }^{1}$ \\ * shared first authorship
'Department of Preventive and Restorative Dentistry, Radboud University Medical Centre, Nijmegen, the Netherlands
${ }^{2}$ School of Dentistry, Federal University of Pelotas, Pelotas, Brasil
${ }^{3}$ Department of Preventive Dentistry, Academic Centre for Dentistry Amsterdam (ACTA),
Amsterdam, the Netherlands

Journal of Dental Research 2015; 94(1):62-68 


\section{Abstract}

This in vitro study investigated whether restoration materials and adhesives influence secondary caries formation in gaps using a short-term in vitro biofilm model.

Sixty enamel-dentin blocks were restored with six different restoration materials with or without adhesives ( $n=10$ per group) with a gap: 1) Clearfil AP-X composite, 2) Clearfil AP-X composite + SE Bond, 3) Clearfil AP-X composite + Protect Bond, 4) Filtek Silorane composite, 5) Filtek Silorane composite + Silorane System adhesive and 6) Tytin amalgam.

Specimens were subjected to an intermittent 1\% sucrose biofilm model for 20 days to create artificial caries lesions. Lesion progression in the enamel-dentin next to the different materials was measured in lesion depth (LD) and mineral loss (ML) using transversal wavelength independent microradiography (T-WIM). A regression analysis was used to compare the LD and the ML of the different restoration materials at four measurement locations: one location at the surface of the enamel, one location at the wall of the enamel, and two locations at the wall of the dentin.

A statistically significant effect of AP-X composite with Protect Bond was found for LD and ML at the WallDentin1 location, leading to less advanced wall lesions. An additional finding was that gap size was also statistically significant at the two wall locations in dentin, leading to increasing lesion progression with wider gaps.

In conclusion, adhesives can influence wall lesion development in gaps. Protect Bond showed significantly less caries progression compared to bare restoration materials or other adhesives in this short-term in vitro biofilm model. 


\section{Introduction}

Because most clinical studies show more secondary caries development for composite restorations than for amalgam restorations in high-caries-risk patients (Bernardo et al., 2007; Soncini et al., 2007; Opdam et al., 2010; Kuper et al., 2012;), secondary caries has often been related to the restorative material used.

Restorative materials may influence the secondary caries development in several ways. Differences in the bacterial colonization and/or retention of restorative materials may play a role. It has been reported that composite and ceramic materials show thicker biofilms than glass ionomers (de Fucio et al., 2009). Some materials can release ions with cariostatic properties that may reduce the caries development through inhibition of bacterial growth. Amalgam, for instance, releases cariostatic agents, such as Ag, Cu and Zn ions (Nunez et al., 1976; Orstavik, 1985; Morrier et al., 1998). Other materials, like glass ionomer cement, release fluoride, which enhances remineralization. In vivo plaque studies have shown that levels of lactic acid-producing bacteria in the plaque present on restorations surfaces are significantly higher on resin composite restorations than on either amalgam or glass ionomer (Svanberg et al., 1990; Hansel et al., 1998; Zalkind et al., 1998).

To counteract secondary caries, manufacturers of restorative materials developed new materials with other properties. Silorane-based composites show lower polymerization shrinkage (Lien and Vandewalle, 2010) and lower quantity of adhering streptococci compared to methacrylate-based composites in vitro (Buergers et al., 2009). Also, adhesives have been developed with the promise of having anticaries properties through the presence of an antibacterial monomer, e.g., 12-methacryloyloxydodecylpyridinium bromide (MDPB) (Imazato et al., 1994; Imazato et al., 1999). In a recent in situ study evaluating the secondary surface caries development next to different restoration materials with optimal adhesion and adaptation, it was shown that a microhybrid composite bonded with an MDPB adhesive showed less mineral loss than amalgam (van de Sande et al., 2014)

Secondary caries is also thought to be influenced by the marginal seal of the restoration, with a good marginal seal considered a protection against secondary caries. The marginal seal may depend on many factors, such as the site or extension of restoration, matrix placement, skills of the operator, moisture control, and amount of polymerization shrinkage. Composite placement is a more technique-sensitive method than placement of amalgam or glass ionomer, and composite shows polymerization shrinkage. Therefore, it is suspected that composite may also be more susceptible to secondary caries due to the presence of restoration gaps. In a recent in situ study (Kuper et al., 2014) it was observed that in gaps with a minimum width of $68 \mu \mathrm{m}$ (and wider) wall lesions were able to develop. 
Many studies have investigated the anticaries effect of different restorative materials with a good marginal seal: however, there is no literature showing the influence of different materials when the marginal seal is lacking due to defects or gaps at the interface. Because marginal degradation has been demonstrated to increase with time (Dickinson et al., 1993; Wendt and Leinfelder, 1994) this is very clinically relevant. Moreover, most studies evaluating the effect of gaps on caries development have studied restorative materials without adhesive layers, and the effect of the adhesive is unclear.

Therefore, this study investigated whether different restoration materials and adhesives influence the secondary caries formation in gaps using a short-term in vitro biofilm model.

\section{Materials and methods}

\section{Preparation of the samples}

Dentin-enamel block samples $(3.2 \times 3.2 \times 2.0 \mathrm{~mm} ; \mathrm{n}=60)$ were cut from bovine incisors and polished with 800 grit paper (Siawat, Abrasives, Frauenfeld, Switzerland), see Figure 3.1. Block samples $(3.2 \times 3.2 \times 2.0 \mathrm{~mm})$ of the following restoration materials were made:

Clearfil AP-X composite (Kuraray Medical Inc, Okayama, Japan) $(n=10)$

Clearfil AP-X composite + SE Bond (Kuraray) $(n=10)$

Clearfil AP-X composite + ProtectBond (Kuraray) $(n=10)$

Filtek Silorane composite (3M ESPE, St. Paul, MN, USA) $(n=10)$

Filtek Silorane composite + Silorane System adhesive (3M ESPE) $(n=10)$

Tytin amalgam (Kerr Corporation, Orange, CA, USA) $(n=10)$.

The composite resin materials were condensed in a putty mold of $3.2 \times 3.2 \times 2.0 \mathrm{~mm}$ and light cured for 20 seconds. If the complete adhesive system (primer + bonding) was used in combination with the composite, the primer was applied first (and cured, if necessary according to manufacturer's instructions) in the mold and subsequently the bonding, resembling the clinical situation with primer toward the side of the tooth substrate. The amalgam material was mixed for 17 seconds and condensed in the mold with a mechanical condensor (Amal-Pak, JR Rand Corporation, Freeport, NY, USA). Excess material of the amalgam blocks was removed by grinding it with 800 grit paper one day after setting.

First, the enamel-dentin blocks were mounted plan parallel on polystyrene bars (Stripstyrene, Item No. 176, .100 x .125", Evergreen scale models, Kirkland, WA, USA) of $3.2 \times 2.5 \times 15 \mathrm{~mm}$ with flowable composite (GrandioSO Flow, Voco, Cuxhaven, 

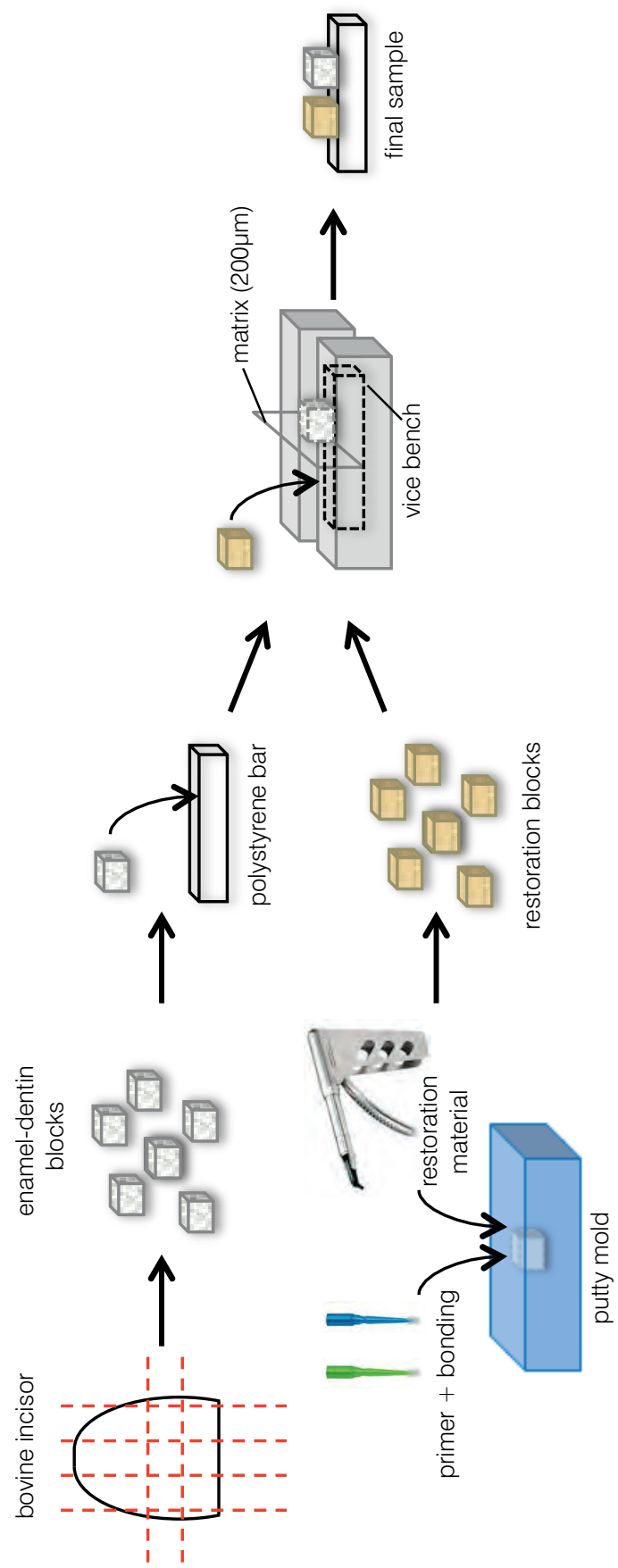

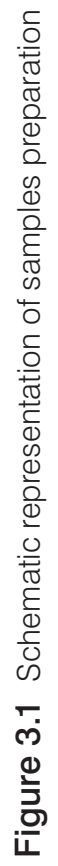


Germany). Then, the samples were secured in a small vice bench. In the vice bench, a matrix of $200 \mu \mathrm{m}$ was placed perpendicularly. With the matrix in place, the restoration blocks also were mounted on the polystyrene bars with flowable composite, with the aim to create a fixed gap of about $250 \mu \mathrm{m}$ between the restoration material and the enamel-dentin block, see Figure 3.1. For the purpose of the microradiographical method used, utmost care was taken to position the top surface of the enamel and the interface surface in such a way that when placed in the microradiography holder, they were parallel to the central ray of the X-ray beam.

\section{Sterilization of the samples}

Samples were kept moist in deionized distilled water, individually sealed within thin plastic films, and placed into thin plastic bags. Subsequently, the samples were placed at $3 \mathrm{~cm}$ from the radiation source and sterilized with gamma irradiation from a cobalt-60 source with particle energies of $1.25 \mathrm{MeV}$ and submitted to $533.53 \mathrm{~Gy} / \mathrm{min}$, with a total dose of 4.08 KGy (Theratronics, Eldorado 78, Best Theratronic LTDA, Ottawa, ON, Canada). The sterilization procedures were carried out at the Regional Center of Oncology/Radiotherapy Service, Faculty of Medicine (Federal University of Pelotas, Pelotas, RS, Brazil).

\section{Biofilm model}

The specimens were subjected to the biofilm model described by van de Sande et al. (2011). Human saliva was used as the inoculums, and the enamel-dentin blocks were the substratum. The nutrient growth medium used for the experiment was a chemically defined medium enriched with mucin (DMM), pH 6.8 (Wong and Sissons, 2001). Biofilms were grown under intermittent sucrose exposure.

For the experiment fresh stimulated saliva was collected from one healthy subject (male, aged 34). Saliva was collected in the morning (during fasting) and the volunteer abstained from oral hygiene for $24 \mathrm{~h}$ prior to collection. The sterilized specimens were transferred aseptically into sterile wells (24-well tissue culture plate; TPP - Techno Plastic Products, Trasadingen, Switzerland), and $0.4 \mathrm{ml}$ of homogenized saliva was dripped in each gap of the specimens. After 1 hour incubation at $37^{\circ} \mathrm{C}$, the saliva was aspirated and $2.2 \mathrm{ml}$ of DMM 1\% sucrose was added. After $6 \mathrm{~h}$ the growth medium was replaced for DMM without sucrose. DMM renewal was performed until the end of the experiment, alternating medium with (6 h) and without sucrose (18 h). The biofilms were incubated anaerobically with increased $\mathrm{CO}_{2}$ by using the Anaerobac ${ }^{\circledR}$ system (Probac do Brasil produtos Bacteriológicos Ltda, Santa Cecília, SP, Brazil), in anaerobic jars for up to 20 days at $37^{\circ} \mathrm{C}$ without shaking. 


\section{Transversal Wavelength Independent Microradiography (T-WIM)}

T-WIM pictures of the specimens were made at baseline (T0) and after 20 days (T20) using the method of Thomas et al. (2006). The settings for the microradiography were $60 \mathrm{kV}, 30 \mathrm{~mA}$ at an exposure time of 8 seconds. A step wedge with the same absorption coefficient as tooth material (a 94\% Al / 6\% Zn alloy) was used for proper quantitative measurement of lesion depth (LD) and mineral loss (ML).

\section{Film Processing and image measurements}

After exposure the films were developed (10 min), fixed (7 min), rinsed, and dried. A digital image of each sample was recorded with a light microscope (Leica Microsystems, Wetzlar, Germany) with a magnification of 10x and a complementary metal oxide semiconductor camera (Canon EOS 50D, Tokyo, Japan). Microradiographs were quantitatively assessed for the presence of wall lesions and surface lesions. A lesion with a progressing front parallel to the outer surface of the tooth sample was considered an outer surface lesion. A wall lesion was defined as a lesion progressing perpendicularly to the tooth-restoration interface. LD and ML for T-WIM were defined as the distance on the microradiograph between the thresholds 8 and 78.3 vol\% mineral for enamel and between 8 and $43.2 \%$ mineral for dentin (Thomas et al., 2006). Each sample was measured at four locations using a software program developed in our laboratory, see Figure 3.2:

- location Surface, surface lesion in enamel: at $400 \mu \mathrm{m}$ distance from the tooth restoration gap

- location Wall Enamel, wall lesion in enamel: $200 \mu \mathrm{m}$ above the enamel-dentin junction (EDJ)

- location Wall Dentin1, wall lesion in dentin: $200 \mu \mathrm{m}$ below the EDJ

- location Wall Dentin2, wall lesion in dentin: $800 \mu \mathrm{m}$ below the EDJ

Baseline measurements (T0) were subtracted from measurements after 20 days (T20) to estimate true lesion depth and mineral loss at T20. The subtracted values were used in the statistical analysis.

From previous experience, we knew that gaps made under standardized circumstances may still vary in size, so gap sizes were measured on the baseline T-WIM picture.

\section{Statistical analysis}

A regression analysis was used to compare the $L D$ and the $M L$ of the different restoration materials at the four measurement locations. Differences in gap size between restoration materials were corrected for, and amalgam was used as the reference material. 
TO
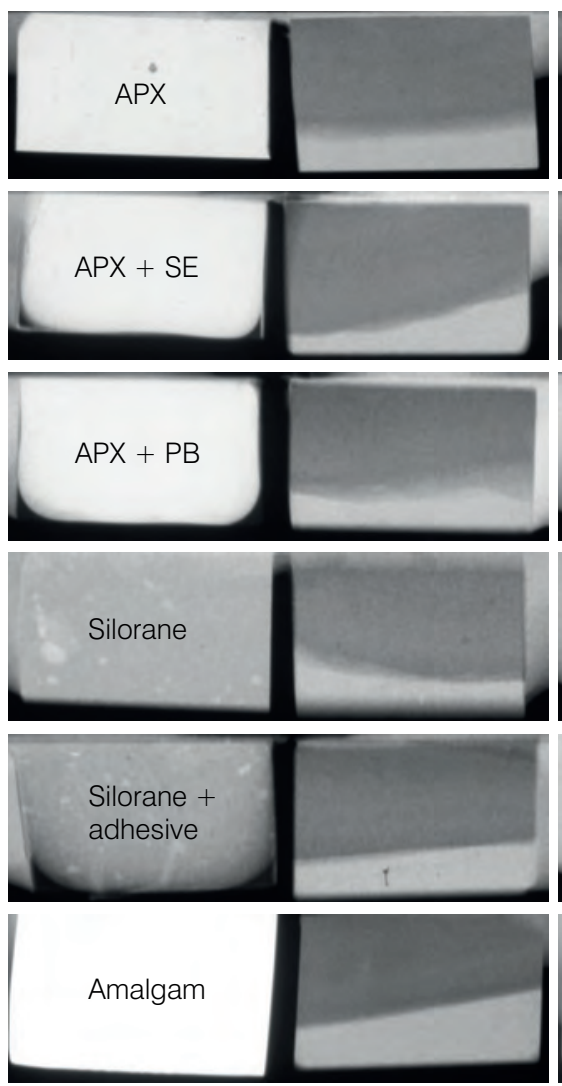

$\rightarrow$ surface $\longrightarrow$ wall enamel
T20

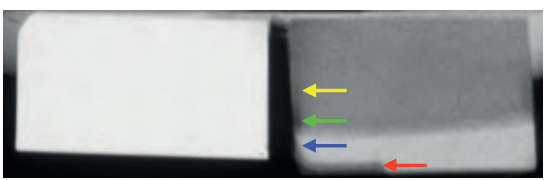

pooling
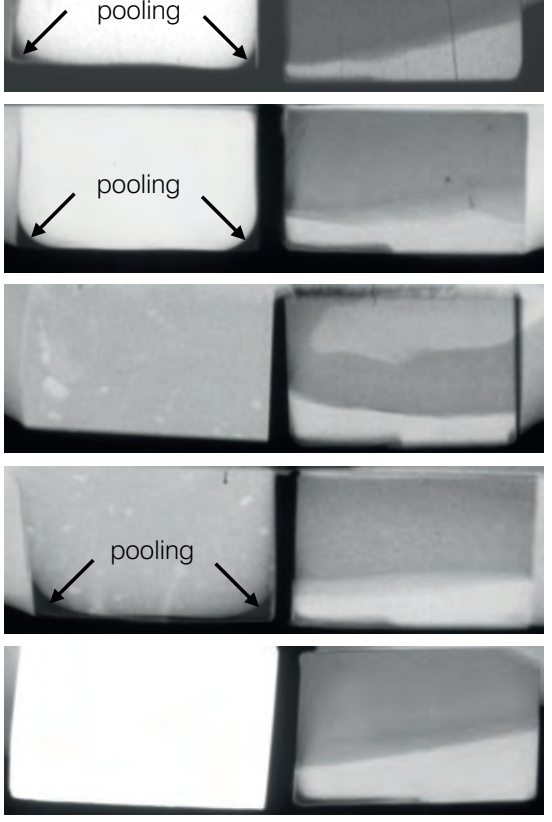

$\longrightarrow$ wall dentin1

$\longrightarrow$ wall dentin2

Figure 3.2 Examples of T-WIM pictures of each restoration material at baseline (T0) and after 20 days (T20) with caries development. Measurement locations are pointed out by colored arrows 


\section{Results}

From the 60 specimens, two specimens ( $\mathrm{n}=1$ AP-X-SE, $\mathrm{n}=1$ Silorane) were discarded due to fracture of the enamel-dentin block of the polystyrene bar. One specimen ( $n=1$, Silorane + system adhesive) could not be measured as accidentally no baseline T-WIM picture was made. From one specimen ( $n=1$, amalgam) only the LD and ML of the dentin locations could be analyzed because of insufficient enamel thickness.

Visual assessment of the T-WIM pictures, of which typical examples are shown in Figure 3.2, showed that surface lesions and wall lesions developed in all groups.

The mean gap sizes, as measured on the microradiographs for the different restoration materials, are amalgam $=305 \mu \mathrm{m}(\mathrm{SD}=79 \mu \mathrm{m}), \mathrm{AP}-\mathrm{X}=329 \mu \mathrm{m}(\mathrm{SD}=$ $61 \mu \mathrm{m}), \mathrm{AP}-\mathrm{X}+\mathrm{SE}=384 \mu \mathrm{m}(\mathrm{SD}=80 \mu \mathrm{m}), \mathrm{AP}-\mathrm{X}+\mathrm{PB}=358 \mu \mathrm{m}(\mathrm{SD}=44 \mu \mathrm{m})$, Silorane $=373 \mu \mathrm{m}(\mathrm{SD}=33 \mu \mathrm{m})$ and Silorane +adhesive system $=388 \mu \mathrm{m}(\mathrm{SD}=$ $61 \mu \mathrm{m})$. The overall range of the gap sizes was 213-578 $\mu \mathrm{m}$. There were no significant differences in gap size between the different groups.

In Figure 3.3, the mean values of $L D$ and $M L$ of each material at the four different locations are shown in a bar chart. AP-X + PB shows the lowest LD and ML at all four locations, except for location Wall Dentin2, where the LD of AP-X is the lowest. In general, lesion depth was higher in dentin than in enamel at wall locations.

Table 3.1 shows the estimated effect of the various restorative materials on LD and $\mathrm{ML}$ increment at the four locations after multiple linear regression analysis. Amalgam was used as the reference material for analysis. A statistically significant effect of AP-X-composite with Protect Bond was found for LD and ML at the WallDentin1 location, leading to less advanced wall lesions. The effect of the gap size on lesion progression was statistically significant at the WallDentin1 and WallDentin2 locations with effects of 0.24 and 0.30 for LD, respectively, resulting in an extra 24 or $30 \mu \mathrm{m}$ of lesion depth for every $100-\mu \mathrm{m}$ increase in gap size.

\section{Discussion}

In this short-term in vitro biofilm study, we found that adhesives might influence the secondary caries formation in gaps. In comparison with amalgam, AP-X composite with a layer of Protect Bond showed significant less caries development in dentin. The other restoration materials and adhesives did not differ significantly from amalgam in caries development. These findings are similar to the findings of the in situ study of van de Sande et al. (2014), which also showed a decrease in caries development next to AP-X composite with Protectbond. In the study of van de Sande et al., however, only surface lesions (in dentin) were analyzed, in contrast to this study 


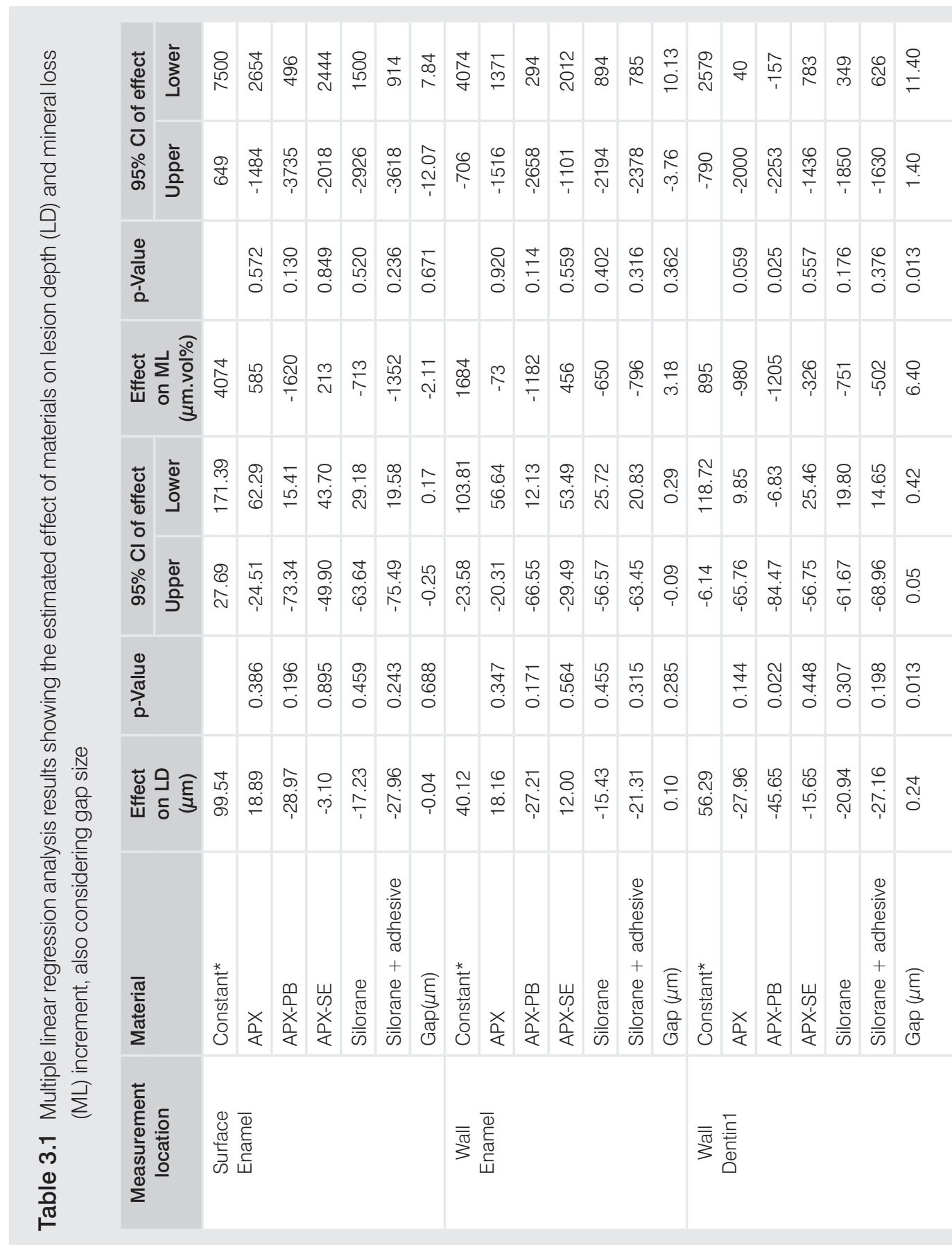




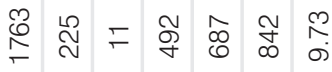

Mineral loss ( $\mu \mathrm{m}$. vol\%)

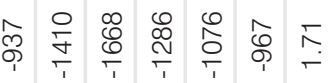

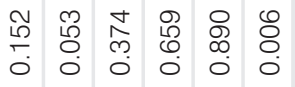

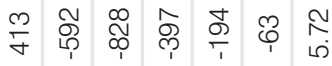

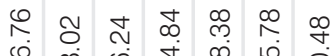

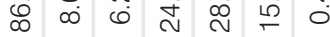

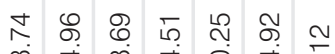

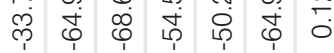

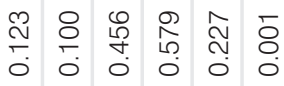

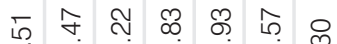

ஸे

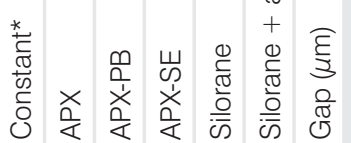

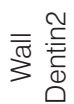

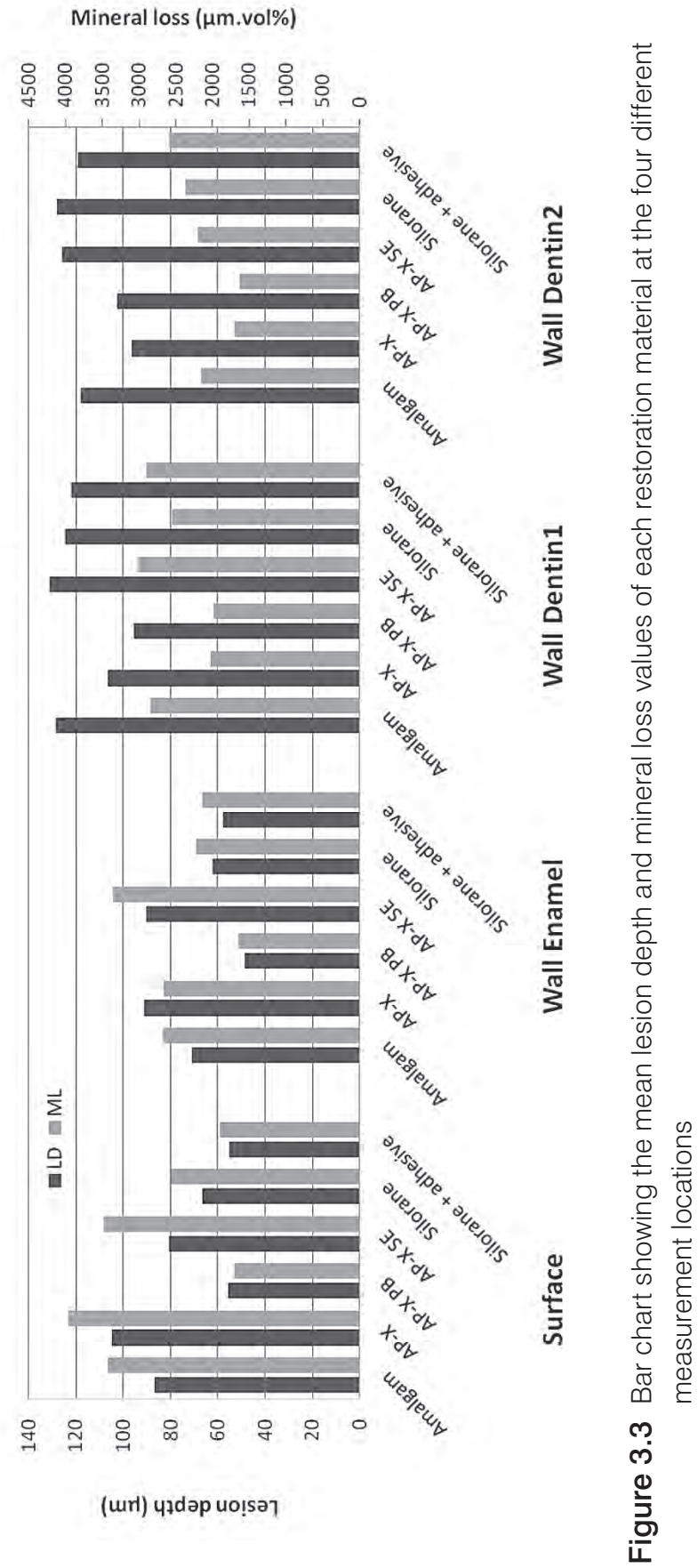


where both surface (enamel) and wall lesions (enamel + dentin) were analyzed. If we compare the LD and ML of the surface lesions of both studies, a similar pattern was seen between all the restoration materials and adhesives of the two studies. In both studies, AP-X + PB showed the lowest caries development, followed by Silorane + adhesive, then AP-X SE, and finally amalgam.

Because we also analyzed caries lesion progression next to AP-X composite without the Protect Bond and we did not observe a significant difference in LD or ML, we can conclude that the anticaries properties come from the Protect Bond. Protect Bond is known to contain a bacterial inhibitor, the monomer MDPB. MDPB is a quaternary ammonium compound that is known to have antibacterial effect due to cationic binding to cell wall components, which disturbs the membrane function and subsequently induces leakage of cytoplasmic material (Scheie, 1989). Protect Bond incorporated MDPB in the primer and exhibited bactericidal effects by the similar mechanism as described above in unpolymerized form. In our study, Protect Bond was cured, as described by the manufacturer's instructions, and during the curing process it is estimated that the degree of cure of dentin bonding components is about 70\% (Imazato et al., 1997). So, probably most of the bactericidal effect comes from the residual portion of uncured MDPB. In this study, Protect Bond might have shown a positive anticaries effect as this study lasted only a short period of three weeks. The potential antimicrobial effect from MDPB is likely to get diluted quickly under clinical conditions. Amalgam, however, had a disadvantage in anticaries effect in this present study because corrosive products, which are believed to contribute to the cariostatic properties, do not form in a three-week period. For these reasons, future research should evaluate the long-term anticaries effect of aged restorative materials in a clinical setting.

In this study, there were some issues in making the samples. From previous experience, we knew that intentional gaps might end up around $60 \mu \mathrm{m}$ larger than intended. Gaps in this study were on average $150 \mu \mathrm{m}$ larger than intended, probably because dentin-enamel blocks and restoration material blocks were made separately from each other and then fixed together onto a polystyrene bar. We also observed some pooling of the primer-bonding agent at the bottom of the mold, which can be seen in Figure 3.2 on the surface of the restoration block. Because we wanted to simulate the clinical situation, we applied primer and bonding agent in the whole mold (like in a box), after which this mold was filled with the restoration material. Pooling is a phenomenon also seen in clinical situations, especially at box preparation angles (Pamir et al., 2010). We would like to emphasize that there was also primer and bonding agent present at the wall sides.

A secondary finding of this study was that at the dentin wall locations, a significant gap size effect was present. In a previous in situ study (Kuper et al., 2014), we could not observe any clear trend for increasing lesion progression with wider gaps. Gap 
sizes of $50,100,200$ and $400 \mu \mathrm{m}$ were compared in the in situ study and only the $50-\mu \mathrm{m}$ gap group showed a slight indication (not significant) of reduced lesion depth. Extrapolating the results of the present study, we would have expected a difference in lesion depth in the Kuper 2014 study between the 200- $\mu \mathrm{m}$ and 400- $\mu \mathrm{m}$ gap group of about 48 to $60 \mu \mathrm{m}$, a difference that would have been statistically significant. We explain these differences in findings by the patient factor present in the in situ study, which was not present in the in vitro study. We assume that, clinically, the caries susceptibility of the patient may override the effect of gap size on secondary caries development.

In this study, we chose to use the saliva of only one person as the inoculum, because this saliva was used in previous studies and we knew that it reproducibly induced caries. This means, however, that there was no interpersonal variation in the saliva composition. Therefore, the anticaries effect of Protect Bond shown in this in vitro study, should also be studied in clinical studies because the caries susceptibility factors of the patient may also modify the effect of Protect Bond.

Enamel-dentin samples were used in this study. It was observed that just beneath the enamel, the caries wall lesion was deepest. We hypothesize that this is due to the effect that when dentin and enamel are demineralizing in close proximity, the dentin, which is more soluble, provides the surrounding fluid with dissolution products, which reduces the dissolution of the enamel by raising the saturation level (Lynch and Ten Cate, 2006). Lateral spread of caries lesions underneath enamel due to structural differences of the tissues was shown to be an unlikely explanation (Ekstrand et al., 1998).

In conclusion, within the limitations of the present study, adhesives can influence wall lesion development in gaps. In this biofilm model, amalgam did not show reduced secondary caries progression in dentin compared to composite materials. Also, there was no significant difference for caries development between different composite materials. AP-X composite with Protect Bond, however, showed significantly less caries progression compared with bare restoration materials or other adhesives in this short-term in vitro biofilm model.

\section{Acknowledgment}

This study was funded by the National Institutes for Health $(246 \mathrm{NIH})$, grant number 1R01DE021383-01, under call RFA-DE-10-005 Increasing the service life of dental resin composites. The funders had no role in study design, data collection and analysis, decision to publish, or preparation of the manuscript. The authors declare no potential conflicts of interest with respect to the authorship and/or publication of this article. 


\section{References}

Bernardo M, Luis H, Martin MD, Leroux BG, Rue T, Leitao J et al. (2007). Survival and reasons for failure of amalgam versus composite posterior restorations placed in a randomized clinical trial. Journal of the American Dental Association 138(6):775-783.

Buergers R, Schneider-Brachert W, Hahnel S, Rosentritt M, Handel G (2009). Streptococcal adhesion to novel low-shrink silorane-based restorative. Dental materials : official publication of the Academy of Dental Materials 25(2):269-275.

de Fucio SB, Puppin-Rontani RM, de Carvalho FG, Mattos-Graner Rde O, Correr-Sobrinho L, Garcia-Godoy $F$ (2009). Analyses of biofilms accumulated on dental restorative materials. American journal of dentistry 22(3):131-136

Dickinson GL, Gerbo LR, Leinfelder KF (1993). Clinical evaluation of a highly wear resistant composite. American journal of dentistry 6(2):85-87.

Ekstrand KR, Ricketts DN, Kidd EA (1998). Do occlusal carious lesions spread laterally at the enamel-dentin junction? A histolopathological study. Clinical oral investigations 2(1):15-20.

Hansel C, Leyhausen G, Mai UE, Geurtsen W (1998). Effects of various resin composite (co)monomers and extracts on two caries-associated micro-organisms in vitro. Journal of dental research 77(1):60-67.

Imazato S, Torii M, Tsuchitani Y, McCabe JF, Russell RR (1994). Incorporation of bacterial inhibitor into resin composite. Journal of dental research 73(8):1437-1443.

Imazato S, Kinomoto Y, Tarumi H, Torii M, Russell RR, McCabe JF (1997). Incorporation of antibacterial monomer MDPB into dentin primer. Journal of dental research 76(3):768-772.

Imazato S, Ebi N, Tarumi H, Russell RR, Kaneko T, Ebisu S (1999). Bactericidal activity and cytotoxicity of antibacterial monomer MDPB. Biomaterials 20(9):899-903.

Kuper NK, Opdam NJ, Bronkhorst EM, Huysmans MC (2012). The influence of approximal restoration extension on the development of secondary caries. Journal of dentistry 40(3):241-247.

Kuper NK, Opdam NJ, Ruben JL, de Soet JJ, Cenci MS, Bronkhorst EM et al. (2014). Gap Size and Wall Lesion Development Next to Composite. Journal of dental research 93(7 suppl):108S-113S.

Lien W, Vandewalle KS (2010). Physical properties of a new silorane-based restorative system. Dental materials : official publication of the Academy of Dental Materials 26(4):337-344.

Lynch RJ, Ten Cate JM (2006). The effect of adjacent dentine blocks on the demineralisation and remineralisation of enamel in vitro. Caries research 40(1):38-42.

Morrier JJ, Suchett-Kaye G, Nguyen D, Rocca JP, Blanc-Benon J, Barsotti O (1998). Antimicrobial activity of amalgams, alloys and their elements and phases. Dental materials : official publication of the Academy of Dental Materials 14(2):150-157.

Nunez LJ, Schmalz G, Hembree J (1976). Influence of amalgam, alloy, and mercury on the in vitro growth of Streptococcus mutans: I. Biological test system. Journal of dental research 55(2):257-261.

Opdam NJ, Bronkhorst EM, Loomans BA, Huysmans MC (2010). 12-year survival of composite vs. amalgam restorations. Journal of dental research 89(10):1063-1067.

Orstavik D (1985). Antibacterial properties of and element release from some dental amalgams. Acta odontologica Scandinavica 43(4):231-239.

Pamir T, Kaya AD, Baksi BG, Sen BH, Boyacioglu H (2010). The influence of bonding agents on the decision to replace composite restorations. Operative dentistry 35(5):572-578.

Scheie AA (1989). Modes of action of currently known chemical anti-plaque agents other than chlorhexidine. Journal of dental research 68:1609-1616.

Soncini JA, Maserejian NN, Trachtenberg F, Tavares M, Hayes C (2007). The longevity of amalgam versus compomer/composite restorations in posterior primary and permanent teeth: findings From the New England Children's Amalgam Trial. Journal of the American Dental Association 138(6):763-772.

Svanberg M, Mjor IA, Orstavik D (1990). Mutans streptococci in plaque from margins of amalgam, composite, and glass-ionomer restorations. Journal of dental research 69(3):861-864.

Thomas RZ, Ruben JL, de Vries J, ten Bosch JJ, Huysmans MC (2006). Transversal wavelength-independent microradiography, a method for monitoring caries lesions over time, validated with transversal microradiography. Caries research 40(4):281-291. 
van de Sande FH, Azevedo MS, Lund RG, Huysmans MC, Cenci MS (2011). An in vitro biofilm model for enamel demineralization and antimicrobial dose-response studies. Biofouling 27(9):1057-1063.

van de Sande FH, Opdam NJM, Truin G-J, Bronkhorst EM, de Soet JJ, Cenci MS et al. (2014). The influence of different restorative materials on secondary caries development in situ. Journal of Dentistry (in press).

Wendt SL, Jr., Leinfelder KF (1994). Clinical evaluation of a posterior resin composite: 3-year results. American journal of dentistry 7(4):207-211.

Wong L, Sissons C (2001). A comparison of human dental plaque microcosm biofilms grown in an undefined medium and a chemically defined artificial saliva. Arch Oral Biol 46(6):477-486.

Zalkind MM, Keisar O, Ever-Hadani P, Grinberg R, Sela MN (1998). Accumulation of Streptococcus mutans on light-cured composites and amalgam: an in vitro study. Journal of esthetic dentistry 10(4):187-190. 



\title{
4
}

Secondary caries development in in situ gaps next to composite and amalgam

\author{
NK Kuper ${ }^{1}$ \\ AF Montagner ${ }^{2}$ \\ FH van de Sande 2 \\ EM Bronkhorst ${ }^{1}$ \\ NJM Opdam ${ }^{1}$ \\ MCDNJM Huysmans ${ }^{1}$ \\ 'Department of Preventive and Restorative Dentistry, Radboud University Medical Centre, \\ Nijmegen, the Netherlands \\ ${ }^{2}$ School of Dentistry, Federal University of Pelotas, Brasil
}

Submitted 


\section{Abstract}

This in situ study investigated the secondary caries development in dentin in gaps next to composite and amalgam. For 21 days, 14 volunteers wore a modified occlusal splint containing human dentin samples with an average gap of $215 \mu \mathrm{m}$ ( $\mathrm{sd}=55 \mu \mathrm{m}$ ) restored with three different materials: Filtek Supreme composite, Clearfill AP-X composite and Tytin amalgam. Eight times a day, the splint with samples was dipped in a $20 \%$ sucrose solution for 10 minutes. Before and after caries development, specimens were imaged with Transversal Wavelength Independent Microradiography (T-WIM), and lesion depth (LD) and mineral loss (ML) were calculated. The LD and $\mathrm{ML}$ of the three restoration materials were compared within patients using paired t-tests $(a=5 \%)$.

In total 38 composite samples (Filtek $n=19$ and AP-X $n=19$ ) and 19 amalgam samples could be used for data analysis. AP-X composite presented the highest mean values of $L D$ and $M L$ of the three restorative materials. Amalgam showed statistically significantly less $\mathrm{ML}(\Delta=452 \mu \mathrm{m}$.vol\%) than the combined composite materials $(p=0.01)$. When comparing amalgam to the separate composite materials, only AP-X composite showed higher $\mathrm{ML}(\Delta=515 \mu \mathrm{m} . \mathrm{vol} \%)$ than amalgam ( $\mathrm{p}=0.034)$. Analysis of LD showed the same trends, but these were not statistically significant.

In conclusion, amalgam showed reduced secondary caries progression in dentin in gaps compared to composite materials tested in this in situ model. 


\section{Introduction}

Secondary caries has been demonstrated to be the principal reason for failure of both composite and amalgam restorations (Mjör et al., 2002; Bernardo et al., 2007; Opdam et al., 2007; Opdam et al., 2014; van de Sande et al., 2013). For more than a century, dental amalgam was the material of choice for restoring cavities. When cavities were restored with amalgam, the cavity design had to meet the requirements of the amalgam material and the cavity was usually therefore extended. With the introduction of bonding and composite a more tissue-preserving approach was possible. The adhesive techniques enabled dentists to make smaller preparations and fillings, supporting the principles of minimally invasive dentistry, and this led to a decline in use of amalgam and an increase in use of composites. Also due to the unaesthetic appearance and the concerns about the mercury content (Mitchell et al., 2007) amalgam is used less frequently. Nowadays, the majority of restorations placed are composites.

There are still concerns whether this shift from amalgam to composite is a good development. Composite restorations are suspected to show more secondary caries development than other restorative materials. Recently the Cochrane collaboration $\AA$ published a systematic review about this topic and concluded that there is low-quality evidence that resin composites lead to higher failure rates and risk of secondary caries than amalgam (Rasines Alcaraz et al., 2014). These conclusions are drawn based on only two studies (Bernardo et al., 2007; Soncini et al., 2007) of which the study population were children. Restoration placement in children is more complicated than in adults as their co-operation is lower and their caries risk is usually higher. As composite is a much more technique sensitive material than amalgam, this study population might have influenced the results.

In a retrospective clinical study of Opdam et al. (2010) differences in overall longevity were found between amalgam and composite restorations related to caries risk and restoration size, showing that in high caries risk patients, composites failed relatively more often due to secondary caries and for all caries risk groups amalgams failed more often due to fracture. A clinical study of Kuper et al. (2012), investigating the influence of the cervical margin of class $\|$ restorations ending in enamel or cement, showed no influence of the cervical outline but significantly more secondary caries with composite than with amalgam restorations $(H R=0.51)$ in high caries risk patients. So, although the differences in longevity between amalgam and composite seem to be dependent on restoration size and caries risk of the patient (Opdam et al., 2010), there is evidence that in high caries risk patients secondary caries is more often a reason for failure for composite than for amalgam restorations.

There may be various reasons why composite is related with more secondary caries than amalgam. Composite is able to seal the margins of a restoration due to 
the adhesion between tooth structure and adhesive material, while amalgam does not form an adhesive bond to the tooth like composite does. Secondary caries in composite restorations is linked with failure or degradation of the adhesive interface (Kuper et al., 2013), and increased levels of the cariogenic bacteria Streptococcus mutans at the perimeter (Hansel et al., 1998; Santerre et al., 2001). When the bonding fails, gaps or crevices can develop at the tooth-restoration interface in which a biofilm can thrive and cause caries lesions (Kuper et al., 2013; Kuper et al., 2014). However, amalgam may form corrosion products at the interface over time, which are assumed to seal the gap between tooth and restoration. The relevance of an imperfect seal, often addressed as microleakage, for development of wall lesions is doubtful (Mjör, 2005), as wall lesion development is related to larger gaps clinically (Kidd et al., 1995; Kuper et al., 2014; Thomas et al., 2007). Still, corrosion products may be able to decrease the carogenicity of the biofilm at the tooth-restoration interface as well as in the proximal interdental space as they are very acidic and contain a high chloride ion concentration (Sutow et al., 1991).

In recent studies, which compared secondary caries development next to several restorative materials in vitro (Kuper et al., 2015) and in situ (van de Sande et al., 2014) amalgam was not found to be associated with lower secondary caries progression in dentin compared to composite materials, but in both studies it was shown that certain types of composite materials have a tendency for more secondary caries development. If composites really are more susceptible to secondary caries development than amalgam, does this susceptibility also vary between different types of composite? In light of the above questions, the aim of this study was to compare the development of secondary caries in dentin in the shape of wall lesions at the tooth-restoration interface, using two composite materials and one amalgam material in an in situ model with an interfacial gap.

\section{Materials and methods}

\section{Study design}

The design and protocol of this study were approved by the local ethics committee METC (CMO file nr. 2011/248, NL33528.01.11).

Secondary caries development in gaps next to three restorative materials was evaluated in situ. The three restorative materials used were: Filtek Supreme XTE 2 (A1 body shade, 3M ESPE, St. Paul, Minnesota, USA), AP-X PLT (A2,Clearfil, Kuraray, Okayama, Japan), and Tytin amalgam (Kerr Corporation, Orange, CA, USA). Results of a parallel study evaluating the effect of gap size on secondary caries development have been published before, and more details about the sample production and study design can be found in that publication (Kuper et al., 2014). 
Fourteen volunteers wore a lower modified occlusal splint with buccal flanges holding embedded four metal slots as sample holders, see Figure 4.1A. For three weeks the volunteers were asked to dip the sample holders with samples in a $20 \%$ sucrose-solution 8 times a day for 10 minutes. Once a day some fluoride toothpaste/saliva slurry was applied on the samples. The samples were not cleaned or brushed to promote plaque formation and caries development.

The composite samples consisted of human dentin bars $(15 \mathrm{~mm} \times 3.2 \mathrm{~mm} \times 2.2$. $\mathrm{mm}$ ) in which five slots of $1.9 \mathrm{~mm}$ depth were made with a 012 cylindrical bur. These slots were restored with either AP-X composite or Filtek Supreme composite without any adhesive procedures, using matrices of different thicknesses $(50,100,200,400$ $\mu \mathrm{m}$ and no matrix). The amalgam samples were cut as single blocks of $3.2 \mathrm{~mm} \times 3.2$ $\mathrm{mm} \times 2.2 \mathrm{~mm}$ with at the mesial side a small ridge of approximately $200 \mu \mathrm{m}$. For this study, only the composite samples restored with a 100 or $200 \mu \mathrm{m}$ matrix were selected from the parallel study (Kuper et al., 2014) to achieve a comparable number of samples with gaps of the same width range as the amalgam samples. Mean gaps of the different groups were: Filtek $=210 \mu \mathrm{m}(\mathrm{sd}=62), \mathrm{AP}-\mathrm{X}=233 \mu \mathrm{m}(\mathrm{sd}=50)$ and amalgam $=210 \mu \mathrm{m}(\mathrm{sd}=51)$.

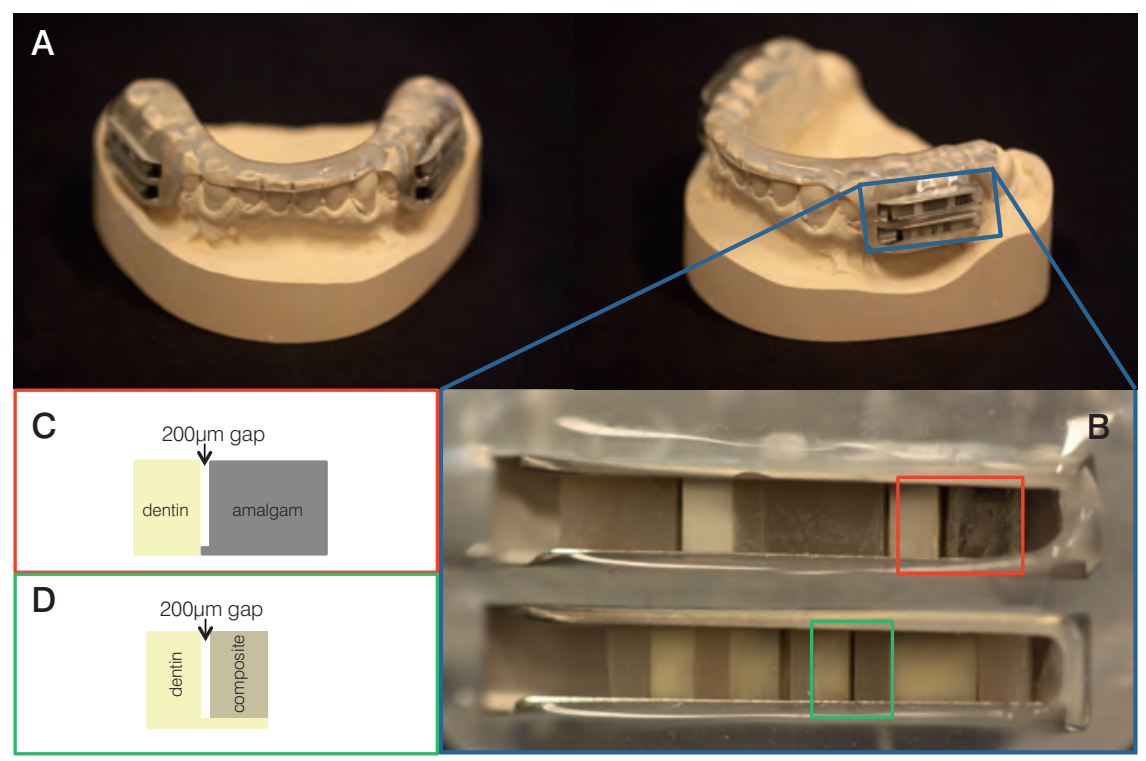

Figure 4.1 A) modified occlusal splint wit gap samples in situ; B) detailed view of slots with samples; C) schematic representation of amalgam-dentin sample; D) schematic representation of composite-dentin sample 
The dentin-composite samples were always located in the two lower slots, placing the two composite materials at the left and right side alternately per volunteer. The dentin-amalgam samples were located in the upper two slots at both sides, left and right, see Figure 4.1B. Data of the amalgam samples on the left side were always compared with the composite samples on the same side.

As the dentin-composite samples were part of sample bars containing different gap sizes, samples analyzed in this study moved from mesial to distal along the possible locations per volunteer. The dentin-amalgam sample was not integrated in a larger sample, due to difficulties with attaching amalgam to dentin with a fixed gap, therefore it was always fixed in the back of the metal slot at the most distal end of the dentin. The amalgam sample had a small ridge of $200 \mu \mathrm{m}$, resulting in a gap of 200 $\mu \mathrm{m}$ between the dentin and the amalgam when an upper sample was positioned in the slot, see Figure 4.1C. During the study, the sample bars were fixated into position using composite material at the entrance of the slots (not shown in Figure).

\section{Transversal Wavelength Independent Microradiography (T-WIM)}

T-WIM images of the samples were made at baseline (T0) and after 21 days (T21) according to the method of Thomas et al. (2006). The settings for the microradiography were $60 \mathrm{kV}, 30 \mathrm{~mA}$ at an exposure time of 8 seconds. A step wedge with the same absorption coefficient as tooth material (94\% Al / 6\% Zn alloy) was used for proper quantitative measurement of lesion depth and mineral loss.

\section{Film Processing and image measurements}

After exposure films were developed (10 min), fixed (7 min), rinsed and dried. Digital images of each sample were recorded with a light microscope (Leica Microsystems, Wetzlar, Germany) with a magnification of 10x and a CMOS camera (Canon EOS 50D, Japan). The digital T-WIMs were edited using the method of Kuper et al. (2014) to distinguish between gaps and caries lesions.

From each sample the wall lesions in the dentin facing the gaps were measured using a software program developed in our lab at a fixed area $400 \mu \mathrm{m}$ under the surface. Baseline measurements (TO) were subtracted from measurements after three weeks (T21), in order to estimate true lesion depth (LD) and mineral loss (ML). The subtracted values were used in the statistical analysis.

\section{Statistical analysis}

Composite samples at the most mesial location and their accompanying amalgam samples were excluded from analysis, as a previous analysis had shown that this location influenced caries development. The LD and ML of the three restoration materials were compared within patients using paired t-tests. The absence of a clustering effect on data-analysis was confirmed. In the first analysis, a comparison 
was made between amalgam and the two composite materials combined. A subsequent analysis compared amalgam with each of the two composite materials separately.

\section{Results}

From the 14 volunteers, only 12 volunteers completed the study, resulting in 48 composite samples (Filtek $n=24$ and AP-X $n=24$ ) and 24 amalgam samples. In the study of Kuper et al. (2014) it was observed that the most mesial position in the metal slot showed significantly less demineralization than the other more distally located positions. Therefore, composite samples at the most mesial position were excluded from analysis together with the associated amalgam samples. This resulted in 38 composite samples (Filtek $n=19$ and AP-X $n=19$ ) and 19 amalgam samples being available for analysis.

In Figure 4.2, the mean values of $L D$ and $M L$ of each restorative material are shown in a bar chart. AP-X composite showed the highest lesion depth and mineral loss.

A statistically significant difference in $\mathrm{ML}$ between the combined composites and amalgam could be observed ( $p=0.01$ ), with composite showing more mineral loss (Table 4.1). When comparing amalgam to the separate composite materials, only AP-X composite showed a statistically significant higher $M L(P=0.034)$ than amalgam (Table 4.1). Analysis of LD showed the same trends, but these were not statistically significant.

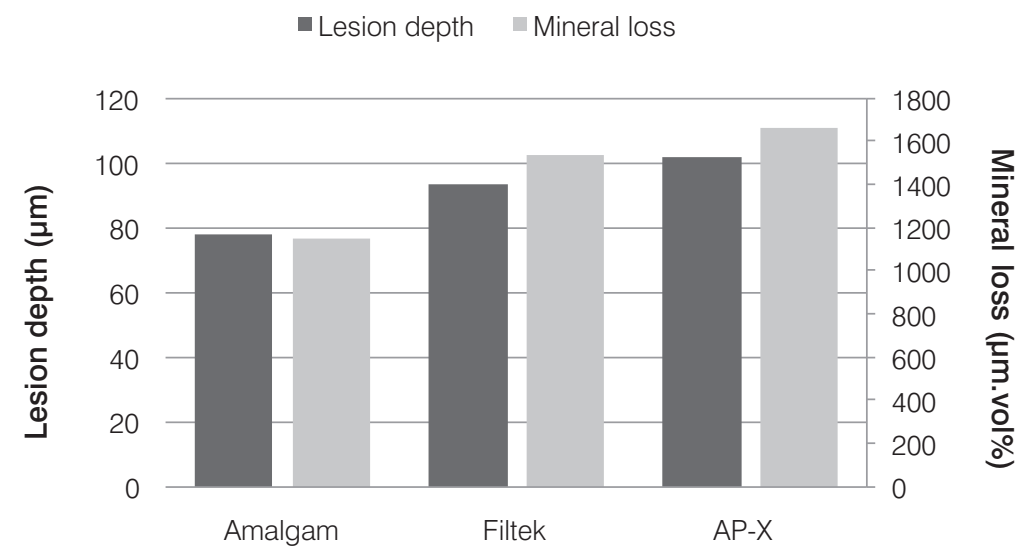

Figure 4.2 Bar chart showing the mean lesion depth and mineral loss values of each restoration material 
Table 4.1 Paired $t$ test results of comparison of lesion depth and mineral loss among restorative materials

\begin{tabular}{|c|c|c|c|c|}
\hline Pair & $\begin{array}{c}\text { Mean difference } \\
(\mu \mathrm{m} \pm \mathrm{SD}) /(\mu \mathrm{m} . \mathrm{vol} \% \pm \mathrm{SD})\end{array}$ & $\mathrm{p}$-Value & \multicolumn{2}{|c|}{\begin{tabular}{|} 
95\% confidence interval \\
of the difference
\end{tabular}} \\
\hline $\begin{array}{c}\text { LD composite - LD } \\
\text { amalgam }\end{array}$ & $20(63)$ & 0.062 & -1 & 40 \\
\hline $\begin{array}{c}\text { LD Filtek - LD } \\
\text { amalgam }\end{array}$ & $15(65)$ & 0.308 & -16 & 47 \\
\hline $\begin{array}{c}\text { LD APX - LD } \\
\text { amalgam }\end{array}$ & $24(63)$ & 0.115 & -6 & 54 \\
\hline $\begin{array}{c}\text { ML composite - ML } \\
\text { amalgam }\end{array}$ & $452(1024)$ & 0.010 & 115 & 789 \\
\hline $\begin{array}{c}\text { ML Filtek -ML } \\
\text { amalgam }\end{array}$ & $389(1089)$ & 0.137 & -136 & 914 \\
\hline $\begin{array}{c}\text { ML APX - ML } \\
\text { amalgam }\end{array}$ & $515(980)$ & 0.034 & 43 & 988 \\
\hline
\end{tabular}

\section{Discussion}

In this in situ study, we found that wall lesions developing in a gap next to composites showed significantly more mineral loss than wall lesions developing next to amalgam.

The longevity of dental restorations is dependent on many factors, including those related to materials, dentist and patient. In this study, we tried to retrieve whether there is actually a material related factor in one of the most common reasons for failure of restorations, secondary caries. However, comparison of different restorative material in a in situ model that only lasted for three weeks has several limitations. Clinically, restoration materials have to serve in the oral environment for several years and consequently material properties change over time due to aging and oral conditions. Even though amalgam had a disadvantage in anticaries effect in this present study, as corrosive products, which are believed to contribute to the cariostatic properties of amalgam, do not form in a shorter period as used in this study (3 weeks), amalgam still did show less secondary caries development than the composite materials. This implies that ions released from the amalgam rather than corrosive products may be the reason for the reduced secondary caries development, or that composite materials have properties that cause more secondary caries development. 
In our previous in vitro study we did not observe amalgam to have lower secondary caries progression in dentin compared to composite materials (Kuper et al., 2015). In that study gaps were larger: an average of $356 \mu \mathrm{m}$ as compared to an average of $215 \mu \mathrm{m}$ in the present study. A wider gap may reduce the effect of the restorative material on the total biofilm and thus on the demineralization of the adjacent dentin. In the present study the average gap of the AP-X composite material was $23 \mu \mathrm{m}$ wider than the average gap of amalgam and Filtek Supreme composite. We assume that this small difference in gap size did not have any influence on the secondary caries development, because even a gap size variation between about 100 and $400 \mu \mathrm{m}$ did not affect caries development in this model (Kuper et al., 2014).

Biodegradation of the composite-dentin adhesive interface is associated with increased microleakage and therefore with secondary caries. Kermanshahi et al. (2010) showed that biodegradation, measured in the levels of Bis-HPPP (a marker of resin-matrix breakdown) released from specimens, already occurred within the first 7 days, with highest amounts measured at 90 days. In that study it was also found that within the expanded marginal gap region (due to the biodegradation) S. Mutans was the most widespread colonizer. Highly characteristic biofilm structures were anchored to the composite resin or dentinal axial walls of marginal gaps spanning $10 \mu \mathrm{m}$ or more. S. Mutans has esterase activities at levels that degrade resin composites and adhesives (Bourbia et al., 2013).

Because the comparison of amalgam with Filtek Supreme composite showed no significant differences in LD and $M L$ and the lesions developing next to this material were slightly smaller than AP-X composite, the authors hypothesize that Filtek Supreme, to some degree, may have more favorable properties regarding secondary caries progression rate. Filtek Supreme is a nanofilled composite with a resin matrix containing a blend of TEGDMA (triethylene glycol dimethacrylate), UDMA (urethane dimethacrylate) and BIS-EMA (Bisphenol A polyethethylene glycol diether dimethacrylate) while AP-X is a highly filled hybrid composite, with a resin matrix consisting of BIS-GMA (Bisphenol A diglycidylmethacrylate) and TEGDMA. The enzymatic degradation of composite materials was shown to be affected according to monomers within the resin matrix system (Finer and Santerre, 2004), which could explain the present findings. The presence of urethane groups may contribute to a lower surface degradation of Filtek Supreme samples, resulting in lower adhesion or metabolic activity of microorganisms (Delaviz et al., 2014). Also, AP-X composite contains fillers with a mean particle size of $3 \mu \mathrm{m}$ and Filtek Supreme contains fillers with a mean size of 5-20 nm. These different fillers may contribute to different surface roughness of the composites. The surface roughness of restoration materials plays role in pellicle formation and biofilm adhesion. Roughening of intra-oral surfaces results in an increased growth rate and maturation of plaque (Quirynen, 1994) which promotes the alteration of the initial chemical composition of the composite by the 
action of the biofilm in situ (Padovani et al., 2014). The use of smaller inorganic fillers in nanocomposites are thought to have lower surface roughness (de Moraes et al., 2009) and might therefore show less secondary caries. However, it must be stressed that in this study the difference between the two composite materials was only very small.

Another in situ study investigating secondary caries formation next to several restorative materials at the surface (not at the interface), found no beneficial influence of the amalgam on secondary caries development, but it showed the effect of an antibacterial bonding for the composite in reducing caries (van de Sande et al., 2014). Therefore, it may well be, even though the present study confirms findings from clinical studies that composites are more related to secondary caries, that differences are not solely related to the composite-amalgam question, but may also be influenced by specific material properties which may be dependent on different types of composites.

In conclusion, within the limitations of the present study, restorative materials can influence wall lesion development in gaps. In this in situ study, amalgam showed reduced secondary caries progression in dentin compared with composite materials.

\section{Acknowledgment}

This study was partially funded by the National Institutes of Health $(246 \mathrm{NIH})$, grant number 1R01DE021383-01, under call RFA-DE-10-005 Increasing the service life of dental resin composites. The funders had no role in study design, data collection and analysis, decision to publish, or preparation of the manuscript. The authors declare no conflicts of interest with respect to the authorship and/or publication of this article. 


\section{References}

Bernardo M, Luis H, Martin MD, Leroux BG, Rue T, Leitao J et al. (2007). Survival and reasons for failure of amalgam versus composite posterior restorations placed in a randomized clinical trial. Journal of the American Dental Association 138(6):775-783.

Bourbia M, Ma D, Cvitkovitch DG, Santerre JP, Finer Y (2013). Cariogenic bacteria degrade dental resin composites and adhesives. Journal of dental research 92(11):989-994.

de Moraes RR, Goncalves Lde S, Lancellotti AC, Consani S, Correr-Sobrinho L, Sinhoreti MA (2009). Nanohybrid resin composites: nanofiller loaded materials or traditional microhybrid resins? Operative dentistry 34(5):551-557.

Delaviz Y, Finer Y, Santerre JP (2014). Biodegradation of resin composites and adhesives by oral bacteria and saliva: a rationale for new material designs that consider the clinical environment and treatment challenges. Dental materials : official publication of the Academy of Dental Materials 30(1):16-32.

Finer Y, Santerre JP (2004). The influence of resin chemistry on a dental composite's biodegradation. Journal of biomedical materials research Part A 69(2):233-246.

Hansel C, Leyhausen G, Mai UE, Geurtsen W (1998). Effects of various resin composite (co)monomers and extracts on two caries-associated micro-organisms in vitro. Journal of dental research 77(1):60-67.

Kermanshahi S, Santerre JP, Cvitkovitch DG, Finer Y (2010). Biodegradation of resin-dentin interfaces increases bacterial microleakage. Journal of dental research 89(9):996-1001.

Kidd EA, Joyston-Bechal S, Beighton D (1995). Marginal ditching and staining as a predictor of secondary caries around amalgam restorations: a clinical and microbiological study. Journal of dental research 74(5):1206-1211.

Kuper NK, Opdam NJ, Bronkhorst EM, Huysmans MC (2012). The influence of approximal restoration extension on the development of secondary caries. Journal of dentistry 40(3):241-247.

Kuper NK, Opdam NJ, Bronkhorst EM, Ruben JL, Huysmans MC (2013). Hydrodynamic flow through loading and in vitro secondary caries development. Journal of dental research 92(4):383-387.

Kuper NK, Opdam NJ, Ruben JL, de Soet JJ, Cenci MS, Bronkhorst EM et al. (2014). Gap Size and Wall Lesion Development Next to Composite. Journal of dental research 93(7 suppl):108S-113S.

Kuper NK, van de Sande FH, Opdam NJ, Bronkhorst EM, de Soet JJ, Cenci MS et al. (2015). Restoration Materials and Secondary Caries Using an In Vitro Biofilm Model. Journal of dental research 94(1):62-68.

Mitchell RJ, Koike M, Okabe T (2007). Posterior amalgam restorations--usage, regulation, and longevity. Dental clinics of North America 51(3):573-589, v.

Mjör IA, Dahl JE, Moorhead JE (2002). Placement and replacement of restorations in primary teeth. Acta odontologica Scandinavica 60(1):25-28.

Mjör IA (2005). Clinical diagnosis of recurrent caries. Journal of the American Dental Association 136(10):1426-1433

Opdam HI, Wan L, Bellomo R (2007). A pilot assessment of the FloTrac cardiac output monitoring system. Intensive care medicine 33(2):344-349.

Opdam NJ, Bronkhorst EM, Loomans BA, Huysmans MC (2010). 12-year survival of composite vs. amalgam restorations. Journal of dental research 89(10):1063-1067.

Opdam NJ, van de Sande FH, Bronkhorst E, Cenci MS, Bottenberg P, Pallesen U et al. (2014). Longevity of posterior composite restorations: a systematic review and meta-analysis. Journal of dental research 93(10):943-949

Padovani G, Fucio S, Ambrosano G, Sinhoreti M, Puppin-Rontani R (2014). In situ surface biodegradation of restorative materials. Operative dentistry 39(4):349-360

Quirynen M (1994). The clinical meaning of the surface roughness and the surface free energy of intra-oral hard substrata on the microbiology of the supra- and subgingival plaque: results of in vitro and in vivo experiments. Journal of dentistry 22 Suppl 1(S13-16.

Rasines Alcaraz MG, Veitz-Keenan A, Sahrmann P, Schmidlin PR, Davis D, Iheozor-Ejiofor Z (2014). Direct composite resin fillings versus amalgam fillings for permanent or adult posterior teeth. The Cochrane database of systematic reviews 3(CD005620 
Santerre JP, Shajii L, Leung BW (2001). Relation of dental composite formulations to their degradation and the release of hydrolyzed polymeric-resin-derived products. Critical reviews in oral biology and medicine : an official publication of the American Association of Oral Biologists 12(2):136-151.

Soncini JA, Maserejian NN, Trachtenberg F, Tavares M, Hayes C (2007). The longevity of amalgam versus compomer/composite restorations in posterior primary and permanent teeth: findings From the New England Children's Amalgam Trial. Journal of the American Dental Association 138(6):763-772.

Sutow EJ, Jones DW, Hall GC, Owen CG (1991). Crevice corrosion products of dental amalgam. Journal of dental research 70(7):1082-1087.

Thomas RZ, Ruben JL, de Vries J, ten Bosch JJ, Huysmans MC (2006). Transversal wavelength-independent microradiography, a method for monitoring caries lesions over time, validated with transversal microradiography. Caries research 40(4):281-291.

Thomas RZ, Ruben JL, ten Bosch JJ, Fidler V, Huysmans MC (2007). Approximal secondary caries lesion progression, a 20-week in situ study. Caries research 41(5):399-405.

van de Sande FH, Opdam NJ, Rodolpho PA, Correa MB, Demarco FF, Cenci MS (2013). Patient risk factors' influence on survival of posterior composites. Journal of dental research 92(7 Suppl):78S-83S.

van de Sande FH, Opdam NJ, Truin GJ, Bronkhorst EM, de Soet JJ, Cenci MS et al. (2014). The influence of different restorative materials on secondary caries development in situ. Journal of dentistry 42(9):11711177. 



\title{
Gap size and wall lesion development next to composite
}

\author{
NK Kuper ${ }^{1}$ \\ NJM Opdam ${ }^{1}$ \\ JL Ruben ${ }^{1}$ \\ JJ de Soet ${ }^{2}$ \\ MS Cenci ${ }^{3}$ \\ EM Bronkhorst ${ }^{1}$ \\ MCDNJM Huysmans ${ }^{1}$
'Department of Preventive and Restorative Dentistry, Radboud University Medical Centre, Nijmegen, the Netherlands
${ }^{2}$ Department of Preventive Dentistry, Academic Centre for Dentistry Amsterdam (ACTA), Amsterdam, the Netherlands
${ }^{3}$ School of Dentistry, Federal University of Pelotas, Pelotas, Brasil

Journal of Dental Research 2014; 93 (7 suppl):108S-113S 


\section{Abstract}

This in situ study investigated whether there is a relationship between gap size and wall lesion development in dentin next to two composite materials, and whether a clinically relevant threshold for the gap size could be established.

For 21 days, fourteen volunteers wore a modified occlusal splint containing human dentin samples with five different interfaces: four gaps of $50 \mu \mathrm{m}, 100 \mu \mathrm{m}, 200$ $\mu \mathrm{m}$, or $400 \mu \mathrm{m}$ and one non-bonded interface without a gap. Eight times a day, the splint with samples was dipped in a $20 \%$ sucrose solution for 10 minutes.

Before and after caries development, specimens were imaged with transversal wavelength-independent microradiography (T-WIM), and lesion depth (LD) and mineral loss (ML) were calculated at the five different interfaces.

After correction for the confounder location (more mesial or distal), a paired t test clustered within volunteers was performed comparing gap widths. Results showed no trend for a relationship between the corrected lesion depth and the gap size. None of the differences in lesion depth for the different gap sizes was statistically significant. Also, the composite material (AP-X or Filtek Supreme) gave no statistically significant differences in lesion depth and mineral loss.

A minimum gap size could not be established, although, in a non-bonded interface without a measurable gap, wall lesion development was never observed. 


\section{Introduction}

Secondary caries is a frequently encountered problem in dental practice and has been widely recognized to be one of the most important reasons for restoration replacement (Mjör, 1997). Secondary caries is defined as a new caries lesion at the margins of an existing restoration (Mjör and Toffenetti, 2000). These lesions have two parts: an outer lesion, which is histologically similar to a primary lesion and formed on the outer surface of the tooth next to the restoration; and a wall lesion, which is a lesion that develops at the interface between the restoration and the tooth (Hals et al., 1974). One of the possible factors in the development of secondary caries is the existence of a gap or defect at the cavity wall. With this considered a weak point, the presence of defective margins leads to many clinical decisions to repair or replace restorations (Gordan et al., 2009), even where caries has not yet developed.

There are two different theories for explaining a possible relationship between gaps and wall lesion development. First, in what we shall call the 'microleakage theory', leakage of bacterial acids into a small gap is considered to be sufficient to cause demineralization and a wall lesion. According to this theory, a wall lesion can develop in any gap, but the wider the gap, the higher the risk. Second, recent changes in the theory of cariology put more emphasis on the importance of the biofilm in driving the caries process in gaps. Clinical and microbiological studies have indicated that microleakage alone does not lead to active demineralization beneath a restoration (Kidd and Fejerskov, 2004). Only where a biofilm can establish itself along the tooth-restoration interface wall lesions may develop. The width of the gap needed for such a cariogenic biofilm has been roughly estimated to be 400 micrometers (Kidd et al., 1995) or 225 micrometers (Thomas et al., 2007a).

The literature provides no conclusive answer to the question whether a relationship between gap size and wall lesion development exists and, if so, the minimum gap size needed. Results of non-bacterial in vitro, bacterial in vitro and clinical (in situ) studies are conflicting. Nassar and González-Cabezas (2011), in their sucrose cycling microbial caries model, showed that in uniform gaps, the size of the gap was positively correlated with the size of dentinal wall lesions, but they gave no threshold for the size of the gap. Diercke et al. (2009) in their bacterial-based in vitro model, found a statistically significant increase in lesion depth in enamel between a 50- $\mu \mathrm{m}$ gap and a 250- $\mu \mathrm{m}$ gap and in dentin between a 50- $\mu \mathrm{m}$ and a 100- $\mu \mathrm{m}$ gap. Totiam et al. (2007) showed in vitro a trend toward bigger wall lesions associated with larger gaps in both enamel and dentin, but did not establish a threshold for gap size. Finally, the clinical in situ study of Thomas et al. (2007a) gave an average gap size of $225 \mu \mathrm{m}$ (range, 80-560 $\mu \mathrm{m}$ ) needed for the development of wall lesions.

Secondary lesion development has been observed to be more of a problem for composite restorations than for amalgam restorations (Opdam et al., 2010; Kuper et 
al., 2012). This has been suggested as the main reason for the reduced life expectancy of composite (National Institutes of Health, 2009). Composite restorative materials, however, may differ in their relative susceptibility to secondary lesion development. In this study, therefore, we evaluated two composite materials.

The aim of this in situ study was to investigate whether there is a relationship between gap size and wall lesion development next to two composite materials, and whether a clinically relevant threshold for the gap size can be established. The null hypothesis tested was that neither the gap size nor the composite material would influence the lesion depth or mineral loss of wall lesion development.

\section{Materials and Methods}

\section{Study participants}

Fourteen volunteers (six men, eight women, aged 20-57 years, mean age $=30.4$ years) were recruited within the Dental School in Nijmegen, the Netherlands. Exclusion criteria were active caries, periodontitis (DPSI > 2), ASA $>2$ or the wearing of a removable prosthetic appliance in the mandibular jaw.

The study design and protocol were approved by the local ethics committee, METC (CMO file nr. 2011/248, NL33528.01.11)

\section{Preparation of specimens}

Sound human molars were ground flat until all the enamel was removed, see Figure 5.1. The roots were cut off, and the remaining crowns were perpendicularly cut in 56 dentin bars with a fixed width of $3.2 \mathrm{~mm}$ and various lengths. The dentin bars were manually ground with 400-grit paper (Siawat, Abrasives, Frauenfeld, Switzerland) to a height of $2.0 \mathrm{~mm}$. The dentin bars were gas-sterilized with ethylene oxide (Isotron Nederland B.V., Venlo, the Netherlands) (Thomas et al., 2007b).

For each sample, two dentin bars (occlusal surface downward) were placed in a rectangular putty mould with dimensions of $15 \times 3.2 \times 2.5 \mathrm{~mm}$. On the pulpal side, a self-etching primer and bonding agent (SE Bond, Clearfil, Kuraray, Okayama, Japan) were applied according to the manufacturer's instructions, and $0.5 \mathrm{~mm}$ composite was applied, fixing the two dentin bars. For the purpose of the microradiographical method used, utmost care was taken to keep the bars perfectly straight with rectangular angles and to position the top surface of the dentin in such a way that when placed in the microradiography holder, it was parallel to the central ray of the X-ray beam.

In each composite-dentin bar, five slots were made parallel to the dentin tubuli with a 012 cylindrical bur with a depth of $1.9 \mathrm{~mm}$, see figure 3.1A. While the bar was fixed in a mould, four slots were filled with one of the two chosen composites, Filtek 
Supreme XTE (A1 body shade, 3M ESPE, St. Paul, MN, USA) or AP-X PLT (A2,Clearfil, Kuraray, Okayama, Japan), without any adhesive procedures, and with matrices of different thicknesses $(50,100,200$ and $400 \mu \mathrm{m})$ between the dentin and the composite. One slot was filled completely with composite (also not bonded) without any matrix. One interface of this slot was randomly chosen as the control interface without a gap (non-bonded, no gap interface $=N G$ ). The order of the different gap sizes was changed per volunteer, starting with the largest gap of $400 \mu \mathrm{m}$ at the most mesial position (order 400-200-100-50-NG) for the first volunteer and starting with the $200 \mu \mathrm{m}$ gap at the most mesial position (order 200-100-50-NG-400) for the second volunteer and so forth. The samples were polished to remove excess composite material, and the final rectangular composite-dentin bars with gaps had dimensions of $15 \mathrm{~mm}$ (length), 3.2 $\mathrm{mm}$ (width), and $2.2 \mathrm{~mm}$ (height).

Each volunteer received a modified occlusal splint for the mandibular jaw, see figure 3.1C, with buccal flanges holding four embedded metal slots of $20 \mathrm{~mm} \times 3.2$ $\mathrm{mm} \times 2.5 \mathrm{~mm}$. Only the two lower slots were used for this study. The two composite materials were placed at the left or right side alternately per volunteer.

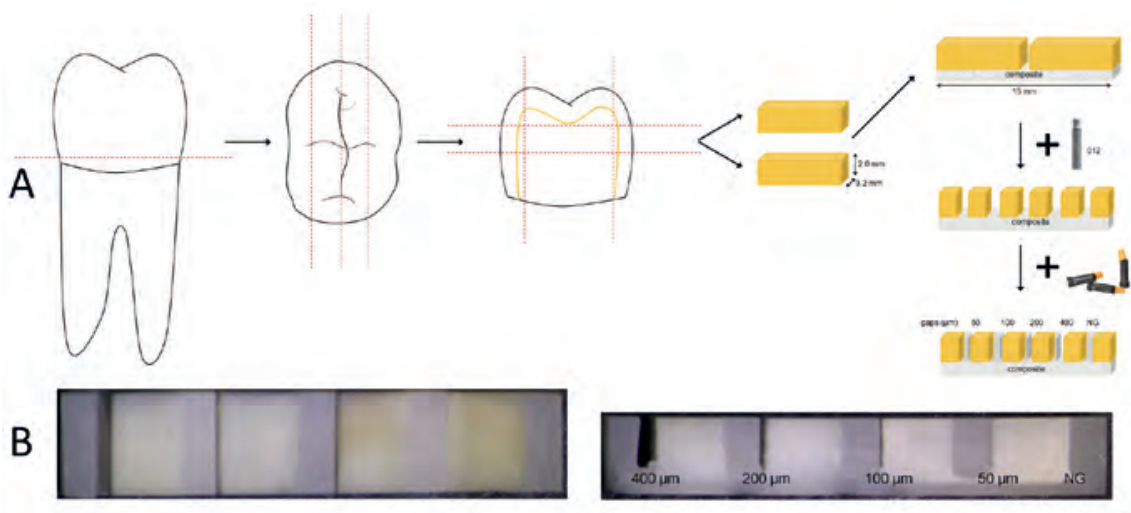

C



Figure 5.1 Sample preparation and sample holder. (A) Schematic representation of samples preparation. (B) Microscopic view of gap samples, 10x magnification. (C) Modified occlusal splint with gap samples in situ 


\section{Experimental protocol}

The occlusal splints were worn for three weeks for 24 hours a day, being removed only during eating, drinking or oral hygiene, with the device kept in a physiologic salt solution. Volunteers were instructed to dip the device with the samples in a $20 \%$ sucrose-solution 8 times a day for 10 minutes. They were asked to keep intervals between different sucrose dippings around an hour or more, but with a minimum of 30 minutes. They were given a diary to record the exact moments of sucrose-dipping. After being dipped in sucrose, the device was rinsed with tap water.

Volunteers were asked to apply some fluoride toothpaste/saliva slurry to the samples once a day (when they brushed their teeth). They were explicitly requested not to clean or brush the samples at all, to promote plaque formation. All instructions were given both orally and in writing.

\section{Transversal Wavelength Independent Microradiography (T-WIM)}

T-WIM pictures were made at baseline (T0) and after 21 days (T21) according to the method of Thomas et al. (2006). The settings for the microradiography were $60 \mathrm{kV}$ and $30 \mathrm{~mA}$ at an exposure time of 8 seconds. A stepwedge with the same absorption coefficient as tooth material (94\% $\mathrm{Al} / 6 \% \mathrm{Zn}$ alloy) was used for proper quantitative measurement of lesion depth and mineral loss.

\section{Film Processing and image measurements}

After exposure films were developed (10 min), fixed (7 min), rinsed, and dried. Digital images of each sample were recorded with a light microscope (Leica Microsystems, Wetzlar, Germany) with a magnification of 10x and a CMOS camera (Canon EOS 50D, Tokyo, Japan). The digital T-WIMs were edited in Adobe Photoshop CS3 (version 10.0; Adobe Systems, San Jose, Ca, USA). The contour of the different gaps in the sample on the baseline picture was selected and copied to the sample of the T21 picture. The selected contour in the gaps was colored black $(R=0, G=0, B=0)$ so that in case of caries development, lesion depth could be distinguished from gap width.

From each sample, the wall lesions in the dentin facing the gaps and in the dentin facing the 'no gap' composite interface were measured with a software program developed in our laboratory at a fixed area $400 \mu \mathrm{m}$ under the surface, see Figure 5.2. Baseline measurements (T0) were subtracted from measurements after three weeks (T21), to estimate true lesion depth (LD) and mineral loss (ML). The subtracted values were used in the statistical analysis.

To obtain the real gap sizes, we measured gaps on the baseline T-WIM image using the same software program. Since gaps were not always perfectly straight, but slightly tapered, the distance between restoration material and dentin was always measured at the outer surface of the gap. 


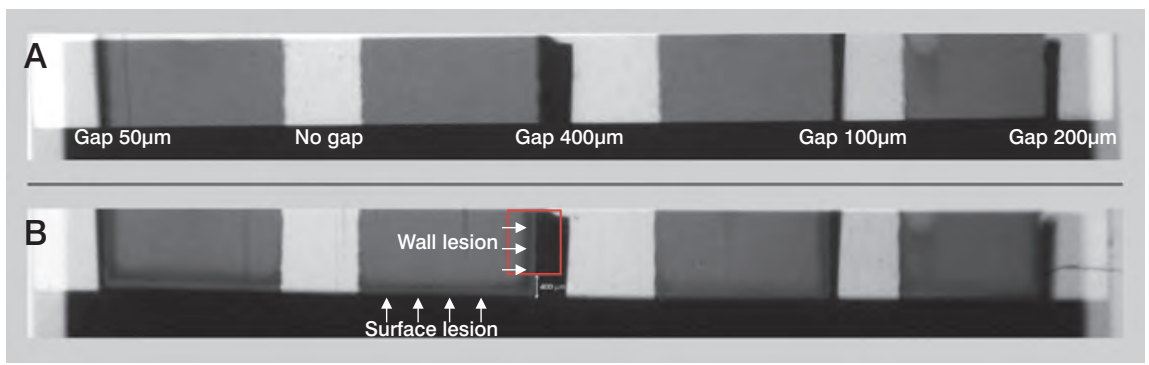

Figure 5.2 T-WIM images of the dentin with composite and the different interfaces (gaps of 50, 100, 200 and $400 \mu \mathrm{m}$, and no gap = NG) at baseline (A) and after 21 days with caries development (B). The area of measurement (red rectangle) starts at $400-\mu \mathrm{m}$ distance from the surface to prevent overlap with the surface lesion

\section{Statistical analysis}

With a linear mixed-effects model, a first analysis was carried out to identify possible confounders that would prohibit comparison of effects within a patient. Included in this analysis was left/right effect, material effect (APX or Filtek Supreme composite), and effect of the location of the gap. Where necessary, a correction for confounding factors was performed. Subsequently, gaps within patients were compared using paired $t$ tests. A Bonferroni correction was applied to correct for multiple testing $(a=$ $0.05 / 6=0.008)$.

\section{Results}

Ten volunteers completed the study successfully in three weeks. Two volunteers dropped out of the study too early for data analysis $(n=1)$ or lost their sample device $(n=1)$. Two volunteers completed only two weeks, but since they did show caries development and effects were evaluated within patients, they were included in the analysis.

Gaps were, on average, 60 to $70 \mu \mathrm{m}$ larger than intended, see Table 5.1.

First analysis of the data with a linear mixed-effects model showed that there was no effect for left/right position ( $p=0.765$ ) or composite material $(p=0.119)$. However, the location of the gap was statistically significant, since the most mesial position showed significantly less demineralization than the other more distally located positions. Therefore, lesion depth values were corrected for location. The difference 
Table 5.1 Gap width and lesion depth per group

\begin{tabular}{|l|c|c|c|c|c|c|c|c|}
\hline Group & \multicolumn{3}{|c|}{ Gap measurements $(\mu \mathrm{m})$} & \multicolumn{3}{c|}{$\begin{array}{c}\text { Uncorrected } \\
\text { lesion depth }(\mu \mathrm{m})\end{array}$} & \multicolumn{2}{|c|}{$\begin{array}{c}\text { Corrected } \\
\text { lesion depth }(\mu \mathrm{m})\end{array}$} \\
\hline & minimum & maximum & mean & mean & SD & mean & SD \\
\hline no gap & N.A. & N.A. & N.A. & 2.4 & 5.7 & not corrected \\
\hline 50 gap & 68 & 202 & 121 & 74.4 & 45.7 & 47.2 & 47.0 \\
\hline 100 gap & 110 & 275 & 169 & 93.8 & 49.4 & 66.1 & 48.9 \\
\hline 200 gap & 166 & 312 & 257 & 89.3 & 58.2 & 58.5 & 52.2 \\
\hline 400 gap & 406 & 587 & 462 & 95.9 & 45.9 & 63.3 & 45.6 \\
\hline
\end{tabular}

Table 5.1a Changes in lesion depth with location

\begin{tabular}{|l|l|l|}
\hline Location & $\Delta \mathrm{LD}(\mu \mathrm{m})$ & p-value \\
\hline 1 Constant (most mesial) & 58.2 & \\
\hline 2 & +37.8 & 0.0025 \\
\hline 3 & +40.8 & 0.0012 \\
\hline 4 & +24.5 & 0.0345 \\
\hline 5 (most distal) & +45.5 & 0.0001 \\
\hline
\end{tabular}

Table 5.1b Mineral loss per group

\begin{tabular}{|c|c|c|c|c|}
\hline \multirow[t]{2}{*}{ Group } & \multicolumn{2}{|c|}{$\begin{array}{c}\text { Uncorrected } \\
\text { mineral loss }(\mu \mathrm{m} . \text { vol\%) }\end{array}$} & \multicolumn{2}{|c|}{$\begin{array}{c}\text { Corrected } \\
\text { mineral loss }(\mu \mathrm{m} . \mathrm{vol} \%)\end{array}$} \\
\hline & mean & SD & mean & SD \\
\hline no gap & 302 & 282 & \multicolumn{2}{|c|}{ not corrected } \\
\hline 50 gap & 1320 & 888 & 1098 & 901 \\
\hline 100 gap & 1591 & 941 & 1377 & 911 \\
\hline 200 gap & 1593 & 948 & 1368 & 916 \\
\hline 400 gap & 1377 & 910 & 1136 & 927 \\
\hline
\end{tabular}


in lesion depth between the two most extreme locations (most mesial vs. most distal) was $45.5 \mu \mathrm{m}(p=0.0001)$. The changes in lesion depth with location can be seen in Table 5.1a. Corrected lesion depths are shown in Table 5.1 and corrected mineral loss is shown in Table 5.1b.

After correcting for this location effect, we performed paired $t$ tests comparing gaps within volunteers for all gap sizes, see Table 5.2. Since the correlation between

Table 5.2 Paired $t$ test results of comparison of lesion depths among gap-width groups

\begin{tabular}{|l|l|l|l|l|}
\hline \multicolumn{1}{|c|}{ Pair } & $\begin{array}{c}\text { Mean } \\
\text { difference } \\
(\mu \mathrm{m} \pm \mathrm{SD})\end{array}$ & p-value & \multicolumn{2}{|c|}{$\begin{array}{c}\text { 95 confidence interval } \\
\text { of the difference }\end{array}$} \\
\hline LD 50 - LD 100 & $-18.8(43.3)$ & 0.044 & -37.1 & upper \\
\hline LD 50 - LD 200 & $-11.3(38.1)$ & 0.161 & -27.3 & 4.8 \\
\hline LD 50 - LD 400 & $-12.0(40.0)$ & 0.165 & -29.3 & 5.3 \\
\hline LD 100 - LD 200 & $7.6(41.5)$ & 0.380 & -9.9 & 25.1 \\
\hline LD 100 - LD 400 & $4.5(38.8)$ & 0.587 & -12.3 & 21.2 \\
\hline LD 200 - LD 400 & $-0.7(47.0)$ & 0.944 & -21.0 & 19.6 \\
\hline
\end{tabular}

*All lesion depth values are corrected for distance from mesial location

Table 5.2a Paired $t$ test results of comparison of mineral loss among gap-width groups

\begin{tabular}{|c|c|c|c|c|}
\hline \multirow[t]{2}{*}{ Pair } & \multirow{2}{*}{$\begin{array}{c}\text { Mean } \\
\text { difference* } \\
(\mu \mathrm{m} . \text { vol\% } \pm \mathrm{SD})\end{array}$} & \multirow[t]{2}{*}{$p$-value } & \multicolumn{2}{|c|}{$\begin{array}{l}95 \% \text { confidence interval } \\
\text { of the difference }\end{array}$} \\
\hline & & & lower & upper \\
\hline ML 50 - ML 100 & $-278(833)$ & 0.115 & -631 & 74 \\
\hline ML 50 - ML 200 & $-270(787)$ & 0.106 & -602 & 62 \\
\hline ML 50 - ML 400 & 21 (898) & 0.910 & -367 & 410 \\
\hline ML 100 - ML 200 & $8(747)$ & 0.957 & -307 & 324 \\
\hline ML 100 - ML 400 & $283(874)$ & 0.135 & -95 & 661 \\
\hline ML $200-M L 400$ & $285(774)$ & 0.091 & -50 & 619 \\
\hline
\end{tabular}

*All mineral loss values are corrected for distance from mesial location 
lesion depth and mineral loss was high $(r=0.795)$, only the analysis for lesion depth is shown in Table 5.2; results for mineral loss are shown in Table 5.2a. None of the differences in lesion depth and mineral loss for the different gap sizes were statistically significant.

\section{Discussion}

In this in situ study, the null hypothesis could not be rejected, since we could not find a relationship between gap size and wall lesion development; no clear trend for increasing lesion progression with wider gaps could be observed. Neither could a minimum gap size be established, although in non-bonded interfaces without measurable gaps, wall lesions never occurred.

In situ studies approximate clinical situation best, but unfortunately they cannot completely mimic the in vivo situation. An unexpected confounder in this in situ study was location effect. The most mesial location showed significantly less demineralization than the more distally located positions. We suspect that this was caused by reduced oral clearance and more plaque accumulation in the back of the buccal vestibule.

Also, compliance of volunteers was challenging. Many volunteers were not used to wearing an occlusal splint (increased height), and since this splint had to be worn 24 hours a day, speech and oral comfort were significantly compromised. One volunteer reported that she unconsciously removed the splint at night during her sleep. Other volunteers had difficulties fulfilling the strict schedule of ' $8 \times 10$ minutes' sucrose dipping each day, because of work or other obligations.

In all volunteers, wall lesions developed in one or more gaps, although the extent ranged from minimal to substantial, but surface lesions developed only in 4 AP-X samples and 5 Filltek supreme samples of the 12 volunteers. This shows that the wall lesions in this study developed independently of the outer surface and can be seen as an entity on their own. In the 'no gap' surfaces, wall lesions never developed at the interface between dentin and composite. Given the relatively short period of time, and since we know that secondary caries in such a model can develop in 21 days, our results show that secondary caries is probably not caused by microleakage as long as there is no hydrodynamic flow due to restoration loading (Kuper et al., 2013). In the 'no gap' samples, outer lesions were sometimes seen to extend slightly deeper next to the composite. Such lesions were also observed in the in situ study of Barata et al. (2012), and we have observed them both in vitro (Kuper et al., 2013; non-bonded samples) and in situ (Thomas et al., 2007a; bonded samples). In our opinion, those lesions, while being directly associated with the tooth-composite interface, are not indisputable wall lesions, since they do not obviously progress from the interface (Hals et al., 1974). Although there is a possibility that the curved lesions extensions 
are the result of microleakage (of acid) in the interface, the fact that such lesion shapes were also found next to bonded samples, where microleakage may be present but only to a very limited degree, points more toward an explanation by the enhanced diffusion of dissolution products at the edge of the tooth surface, accelerating demineralization locally. This is in agreement with an earlier in vitro study wherein different windows were exposed with the use of tape, as opposed to the use of a restorative material with an interface (Ruben et al., 1999).

Unfortunately, all gaps turned out to be wider than intended. The smallest gap measured was $68 \mu \mathrm{m}$, in which a lesion developed of $79.4 \mu \mathrm{m}$ (not corrected for location). The 'gaps' of the non-bonded surfaces could not be measured, since these were too small for our measurement software to distinguish. The authors emphasize that there is not yet a standard for measuring gaps on T-WIM images.

It is known that patient risk factors play an important role in restoration survival (van de Sande et al., 2013a). A large patient factor was also seen in this study. Despite the very highly standardized cariogenic exposure, which would make all volunteers 'high caries risk' as far as the appliance was concerned, we still observed volunteers (with established good compliance) with very little caries development, whereas other volunteers had considerable caries development. Caries progression is probably also influenced by other patient factors, e.g. saliva components, biofilm composition or other oral conditions.

We conclude that gap size is probably not relevant as long as the caries risk is low, but when caries risk is high, even a gap size of $68 \mu \mathrm{m}$ may allow for secondary wall lesion development. These new findings undermine the accepted theory that only in large gaps (>250 $\mu \mathrm{m}$; Mjör, 2005), which enable a cariogenic biofilm to thrive, wall lesions can develop. Since the 'no gap' interfaces never showed wall lesions, and minimal gaps of $68 \mu \mathrm{m}$ did, it may be assumed that the threshold for secondary wall lesion development lies in the range of about $0-70 \mu \mathrm{m}$.

\section{Acknowledgment}

This study was funded by the National Institutes of Health $(246 \mathrm{NIH})$, grant number 1R01DE021383-01, under call RFA-DE-10-005 Increasing the service life of dental resin composites. The funders had no role in study design, data collection and analysis, decision to publish, or preparation of the manuscript. The authors declare no conflicts of interest with respect to the authorship and/or publication of this article. 


\section{References}

Barata JS, Casagrande L, Pitoni CM, De Araujo FB, Garcia-Godoy F, Groismann S (2012). Influence of gaps in adhesive restorations in the development of secondary caries lesions: an in situ evaluation. American journal of dentistry 25(4):244-248.

Diercke K, Lussi A, Kersten T, Seemann R (2009). Isolated development of inner (wall) caries like lesions in a bacterial-based in vitro model. Clinical oral investigations 13(4):439-444.

Gordan VV, Garvan CW, Blaser PK, Mondragon E, Mjor IA (2009). A long-term evaluation of alternative treatments to replacement of resin-based composite restorations: results of a seven-year study. Journal of the American Dental Association 140(12):1476-1484.

Hals E, Andreassen BH, Bie T (1974). Histopathology of natural caries around silver amalgam fillings. Caries research 8(4):343-358.

Kidd EA, Joyston-Bechal S, Beighton D (1995). Marginal ditching and staining as a predictor of secondary caries around amalgam restorations: a clinical and microbiological study. Journal of dental research 74(5):1206-1211

Kidd EA, Fejerskov O (2004). What constitutes dental caries? Histopathology of carious enamel and dentin related to the action of cariogenic biofilms. Journal of dental research $83 \mathrm{Spec}$ No C(C35-38.

Kuper NK, Opdam NJ, Bronkhorst EM, Huysmans MC (2012). The influence of approximal restoration extension on the development of secondary caries. Journal of dentistry 40(3):241-247.

Kuper NK, Opdam NJ, Bronkhorst EM, Ruben JL, Huysmans MC (2013). Hydrodynamic flow through loading and in vitro secondary caries development. Journal of dental research 92(4):383-387.

Mjör IA (1997). The reasons for replacement and the age of failed restorations in general dental practice. Acta odontologica Scandinavica 55(1):58-63.

Mjör IA, Toffenetti F (2000). Secondary caries: a literature review with case reports. Quintessence international 31(3):165-179.

Mjör IA (2005). Clinical diagnosis of recurrent caries. Journal of the American Dental Association 136(10):1426-1433.

Nassar HM, González-Cabezas C (2011). Effect of gap geometry on secondary caries wall lesion development. Caries research 45(4):346-352.

National Institutes of Health (2009). Increasing the service life of dental resin composites. RFA-DE-10-005, http://grants.nih.gov/grants/guide/rfa-files/RFA-DE-10-005.html.

Opdam NJ, Bronkhorst EM, Loomans BA, Huysmans MC (2010). 12-year survival of composite vs. amalgam restorations. Journal of dental research 89(10):1063-1067.

Ruben J, Arends J, Christoffersen J (1999). The effect of window width on the demineralization of human dentine and enamel. Caries research 33(3):214-219.

Thomas RZ, Ruben JL, de Vries J, ten Bosch JJ, Huysmans MC (2006). Transversal wavelength-independent microradiography, a method for monitoring caries lesions over time, validated with transversal microradiography. Caries research 40(4):281-291.

Thomas RZ, Ruben JL, ten Bosch JJ, Fidler V, Huysmans MC (2007a). Approximal secondary caries lesion progression, a 20-week in situ study. Caries research 41(5):399-405.

Thomas RZ, Ruben JL, ten Bosch JJ, Huysmans MC (2007b). Effect of ethylene oxide sterilization on enamel and dentin demineralization in vitro. Journal of dentistry 35(7):547-551.

Totiam P, Gonzalez-Cabezas C, Fontana MR, Zero DT (2007). A new in vitro model to study the relationship of gap size and secondary caries. Caries research 41(6):467-473.

van de Sande FH, Opdam NJ, Rodolpho PA, Correa MB, Demarco FF, Cenci MS (2013a). Patient risk factors' influence on survival of posterior composites. Journal of dental research 92(7 Suppl):78S-83S.

van de Sande FH, Opdam NJM, Truin G-J, Bronkhorst EM, de Soet JJ, Cenci MS et al. (2013b). Do dental materials influence secondary caries development? unpublished data. 



\section{6}

\section{Hydrodynamic flow through loading and in vitro secondary caries development}

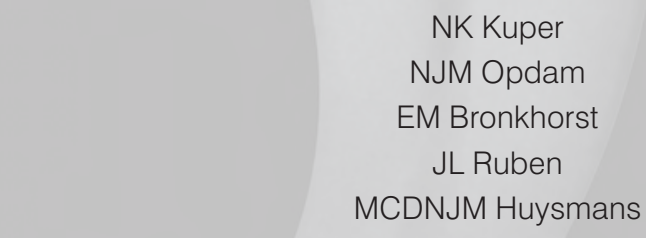

Department of Preventive and Restorative Dentistry, Radboud University Medical Centre, Nijmegen, the Netherlands 


\section{Abstract}

This in vitro study investigated the effect of hydrodynamic flow through mechanical loading on development of secondary caries lesions. Forty-eight bovine tooth specimens (enamel and dentin; size: $3.2 \times 3.2 \times 2.0 \mathrm{~mm}$ ) were restored with resincomposite on polystyrene bars; 18 samples were bonded, and 30 were not bonded. Specimens were suspended in a lactic acid solution ( $\mathrm{pH}=5 ; 14$ days) in a modified brushing machine, and artificial caries lesions were formed. During caries development, specimens were mechanically loaded at the surface of the polystyrene bar, bent so that the tooth-composite interfaces were subjected to opening forces (16x/min). Loads applied were either none (Control Bonded, CB, $n=6$; and Control Non-bonded, CNB, $n=6$ ), 200 gr (NB200, $n=12$ ) or 350 gr (NB350 and B350, both $\mathrm{n}=12)$.

Before and after caries development, specimens were imaged with transversal wavelength-independent microradiography (T-WIM), and lesion depth (LD) and mineral loss (ML) were calculated at four different locations. An independent $t$ test was used to compare the $L D$ and $M L$ at the four different locations.

A statistically significant effect of the level of loading (comparing groups NB200 and NB350) and of the bonding (comparing groups NB350 and B350) could be observed, with a higher load and absence of bonding leading to more advanced lesions. 


\section{Introduction}

Even though secondary caries is usually defined as a new caries lesion next to an existing restoration, there is still debate about the initiation and progression of outer and wall lesions in secondary caries.

One of the assumed factors in the development of secondary caries is the existence of a gap between the restoration and the tooth. The gap size necessary is still subject to discussion.

Mostly in vitro studies have shown that, through microleakage in small microspaces (50 microns and less), bacterial acids can leak in between the tooth-restoration interface and can be sufficient to cause demineralization (Jorgensen and Wakumoto, 1968; Goldberg et al., 1981; Derand et al., 1991; Hodges et al., 1995; Totiam et al., 2007). However, clinical studies have shown that microleakage does not lead to secondary caries (Kidd et al., 1995; Thomas et al., 2007; Kuper et al., 2012). Currently, cariologists emphasize the presence of an active biofilm for development of secondary caries, and a biofilm can grow only along the tooth-restoration interface if there are large gaps (225 microns or more (Kidd et al., 1995; Thomas et al., 2007)) or cavitations present.

Is it possible that there may be other factors than gap size that play a role in the onset of secondary caries?

Demineralization of enamel or dentin in caries is associated with several diffusion and reaction processes. In a small gap, the rate-limiting step is the diffusion of dissolution products away from the demineralizing solid (Ruben et al., 1999; Bollet-Quivogne et al., 2005). It takes time for acids to penetrate the gap and cause demineralization. However, from in vitro studies it is also known that stirring of the demineralization solution diminishes the role of diffusion length (Thomann et al., 1990). So if, in a small gap, the fluid is agitated, the dissolution products will be actively removed from the gap, and therefore this will reduce the role of diffusion.

Mastication and/or bruxism lead to heavy occlusal loading of teeth and restorations. In some studies, occlusal loading has been reported to play a role in the development of non-carious cervical lesions (Romeed et al., 2012; Silva et al., 2012). Also, an in vitro study showed that occlusal loading led to a significant increase in gap formation at the margins of cervical resin based composite restorations (Francisconi et al., 2009), and a clinical study showed that bacterial penetration along the tooth-restoration interface was higher in loaded than in unloaded restorations (Qvist, 1983). One theory of the authors is that if occlusal loading is capable of creating a gap at the tooth-restoration interface, it can also subject a marginal gap to opening and closing forces. This movement at the interface can cause a fluid movement into (at gap opening) and out of (at gap closure) the gap. The authors hypothesized that this hydrodynamic flow mirrors a stirring of the demineralization 
solution, thus reducing the role of diffusion and allowing secondary caries to progress faster. This phenomenon would contribute significantly to an explanation of the rapid caries progression seen clinically in cases where a fixed prosthesis has become detached from one of its abutment teeth.

Therefore, the aim of this in vitro study was to investigate the effect of hydrodynamic flow through mechanical loading on the development of secondary caries lesions.

\section{Materials and Methods}

\section{Preparation of the specimens}

Dentin-enamel block samples $(3.2 \times 3.2 \times 2.0 \mathrm{~mm}, \mathrm{n}=48)$ were cut from bovine incisors and polished with 800-grit paper (Siawat, Abrasives, Frauenfeld, Switzerland). The samples were mounted on polystyrene bars (StripStyrene, Item No. 188, .125 x .188", Evergreen scale models, Woodinville, WA, USA) of $3.2 \times 4.8 \times 25 \mathrm{~mm}$ as following, see Figure 6.1. Undercuts were made in the polystyrene bars on the 3.2- $\mathrm{mm}$ side and in the dentin with a 010 cylindrical bur. The bottom (dentin) side of the samples was spot-etched with a 37\% phosphoric acid gel (Etching Gel, medium viscosity, Ref. 212873, Lot 613096, DMG, Hamburg, Germany), primed (Clearfil SA Primer, Kuraray, Osaka, Japan), bonded (Clearfil Photo Bond, Kuraray) and light-cured according to manufacturer's instruction. The undercuts were filled with resin composite material (Clearfil AP-X, Kuraray) and the tooth samples were placed on top of the polystyrene bars and light cured for 40 seconds. The tooth samples mounted on the polystyrene bars were restored with resin composite material (Clearfil AP-X, Kuraray) parallel to the polystyrene bar by the use of microscope glass slides. The sides of the tooth samples were polished with 800-grit paper to remove possible excess of composite. For the purpose of the microradiographical method used, utmost care was taken to position the tooth-composite interface exactly perpendicular to the polystyrene bar. When the specimens were placed in a microradiography holder, the top surfaces of the enamel and composite and also the interface were positioned parallel to the central ray of the X-ray beam.

For the etching of 18 samples, primer and bonding were used at the toothrestoration interface; for the other 30 samples no bonding procedure was applied. All exposed surfaces of the tooth specimens were covered with nail varnish, except half of the upper enamel surface, to expose the tooth-restoration interface to cariogenic challenge.

\section{Experimental protocol}

The polystyrene bars with restored specimens were suspended (with specimens hanging underneath the bar) in a lactic acid solution $(\mathrm{pH}=5)$ with $0.5 \mathrm{ppm}$ fluoride 

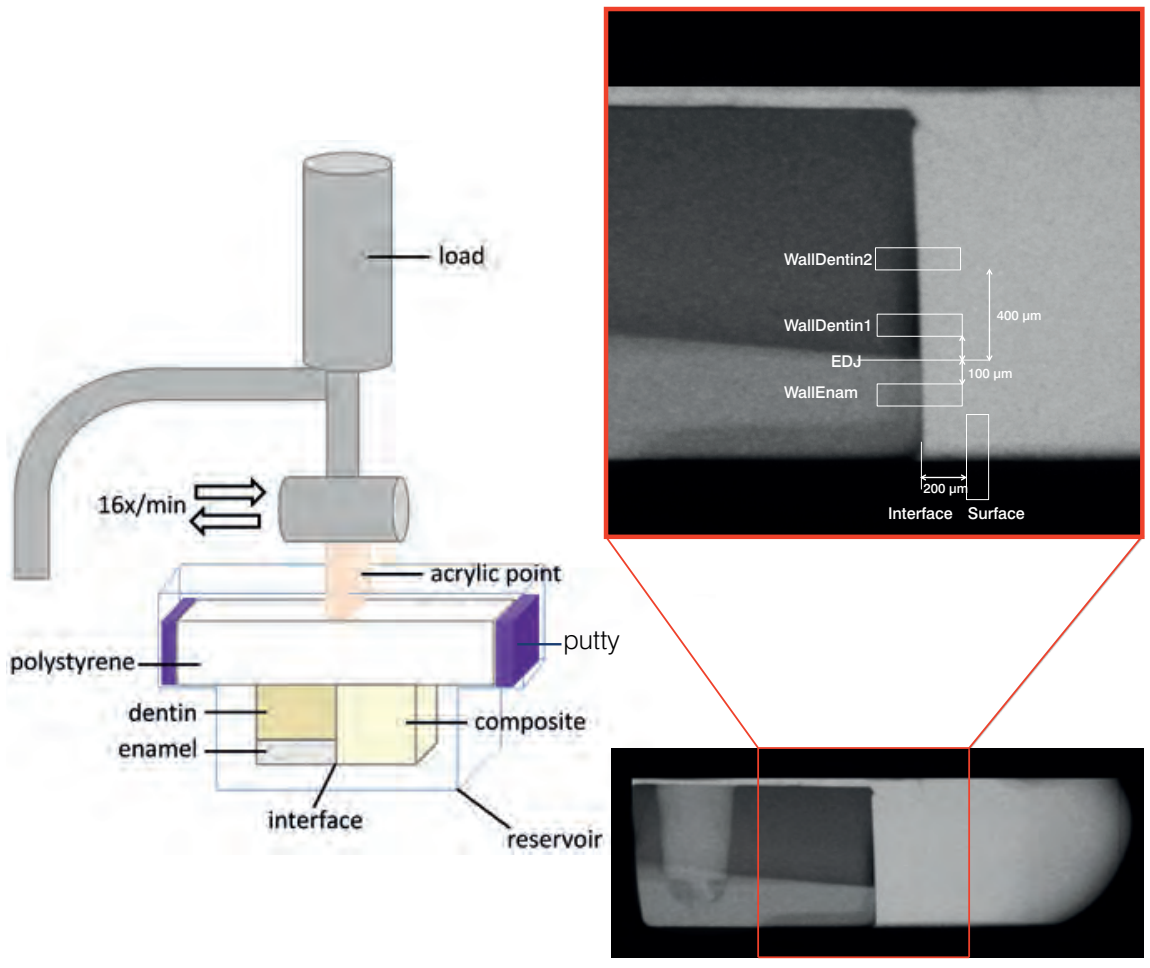

Figure 6.1 Schematic drawing of a specimen loaded in a modified brushing machine and an example of a T-WIM image with the four locations of measurement

(Fluoride Standard, $100.0 \pm 0.5$ ppm sodium fluoride, Orion, Boston, MA, USA), in a modified brushing machine (instead of toothbrushes, acrylic points were mounted). The polystyrene bars rested on the edges of the reservoir, and horizontal movement was limited by a putty mould, see Figure 6.1. The solution was renewed every 7 days. The samples were either not loaded (bonded and non-bonded controls) or mechanically loaded at the surface of the polystyrene bars, which were bent so that the tooth-composite interface was subjected to opening forces (16x/min) for 14 days. The load applied on the samples was either 200 grams or 350 grams, resulting in the following groups: $C N B$, control group $(n=6)$, not bonded, not loaded; $C B$, control group ( $n=6)$, bonded, not loaded; NB200, non-bonded group $(n=12)$, load $=200$ grams; NB350, non-bonded group $(n=12)$, load = 350 grams; B350, bonded group $(n=12)$, load $=350$ grams 


\section{Transversal Wavelength Independent Microradiography (T-WIM)}

T-WIM images were taken at baseline (T0) and after 14 days (T14) according to the method of Thomas et al. (2006). The settings for the microradiography were $60 \mathrm{kV}, 30$ $\mathrm{mA}$ at an exposure time of 8 seconds. A stepwedge with the same absorption coefficient as the tooth material ( $94 \% \mathrm{Al} / 6 \%$ Zn alloy) was used for proper quantitative measurement of lesion depth (LD) and mineral loss (ML).

\section{Film Processing and image measurements}

After exposure, the films were developed (10 min), fixed (7 min), rinsed, and dried. A digital image of each sample was recorded with a light microscope (Leica Microsystems, Wetzlar, Germany) with a magnification of 10x and a CMOS camera (Canon EOS 50D, Japan). Microradiographs were quantatively assessed for the presence of wall lesions and surface lesions. A lesion with a progressing front parallel to the outer surface of the tooth sample was considered an outer surface lesion. A wall lesion was defined as a lesion progressing perpendicularly to the toothrestoration interface. LD and ML for T-WIM were defined as the distance on the microradiograph between the thresholds 8 and 78.3 vol\% mineral for enamel and between 8 and 43.2\% mineral for dentin (Thomas et al., 2006). Each sample was measured using a software program developed in our laboratory at four locations, see Figure 6.1: location Surface, surface lesion in enamel, at 200- $\mu \mathrm{m}$ distance from the tooth restoration interface; location WallEnam, wall lesion in enamel, $100 \mu \mathrm{m}$ above the enamel-dentin junction (EDJ); location WallDentin1, wall lesion in dentin, $100 \mu \mathrm{m}$ below the EDJ; location WallDentin2, wall lesion in dentin, $400 \mu \mathrm{m}$ below the EDJ.

Baseline measurements (T0) were subtracted from measurements after 14 days (T14) for estimation of true lesion depth and mineral loss at T14. The subtracted values were used in the statistical analysis.

\section{Statistical analysis}

An independent $t$ test was used to compare the LD and ML separately for the locations Surface, WallEnam, WallDentin1 and WallDentin2. The influence of the weight of load on the development of caries lesions was analyzed by $t$ tests comparing the groups NB200 versus NB350. The influence of bonding on the development of caries lesions was analyzed by $t$ tests comparing the groups NB350 versus B350.

\section{Results}

From the 48 specimens, one specimen from the group NB350 was discarded due to fracture of the polystyrene bar. Two measurements at location Surface were excluded from analysis, one due to skewed alignment of the enamel (group NB350) and one 


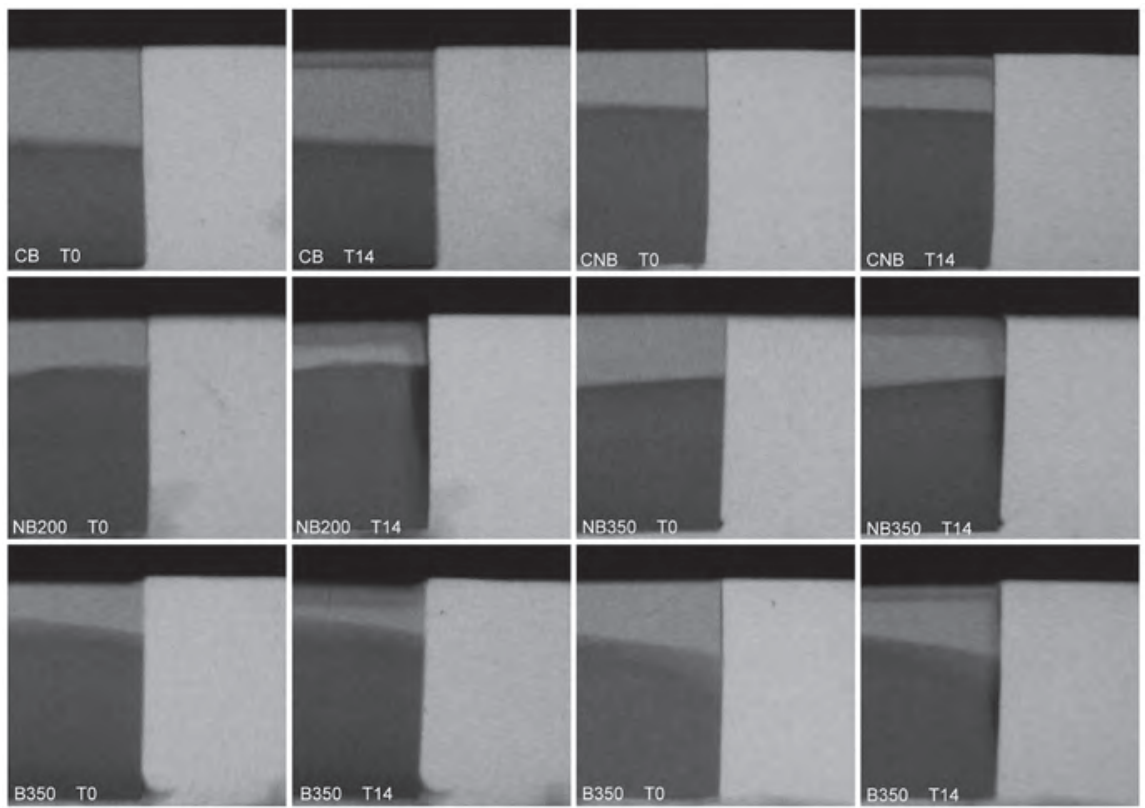

Figure 6.2 T-WIM images of the enamel/dentin-composite interface at baseline (T0) and after 14 days (T14), showing the caries development in one specimen of each group

because of insufficient enamel thickness (group NB350), resulting in unreliable measurements of the LD and ML in the surface lesion. Two measurements at location WallEnam (group NB350) were excluded, since the enamel wall lesion could not be distinguished from the surface lesion.

Visual assessment of the T-WIM images (see Figure 6.2 for examples) showed that surface lesions developed in all groups, and wall lesions developed in all loaded groups without bonding (NB200 and NB350). In the loaded group with bonding (B350) only 3 out of 12 samples developed wall lesions. Despite the fluoride in the demineralization solution, some slight initial erosion of the surface occurred occasionally, in addition to the formation of subsurface lesions. This erosion was included in the LD and ML measurements.

Table 6.1 shows the results for LD and $\mathrm{ML}$ at all locations, with Figure 6.3 showing the results for lesion depth in a box plot. In groups NB200 and B350, wall lesions in enamel were deeper than those in dentin. In group NB350, wall lesions in dentin were deeper than those in enamel. 
Table 6.1 Lesion depth and mineral loss of all groups at the different locations in enamel and dentin

\begin{tabular}{|c|c|c|c|c|c|c|c|c|c|}
\hline \multicolumn{2}{|c|}{ Location } & \multicolumn{2}{|c|}{ Surface } & \multicolumn{2}{|c|}{ WallEnam } & \multicolumn{2}{|c|}{ WallDentin1 } & \multicolumn{2}{|c|}{ WallDentin2 } \\
\hline & & Mean & SD & Mean & SD & Mean & SD & Mean & SD \\
\hline \multirow[t]{5}{*}{$\mathrm{LD}(\mu \mathrm{m})$} & CNB & 162.2 & 18.6 & 0.8 & 1.3 & 2.6 & 3.1 & 0.5 & 2.4 \\
\hline & $\mathrm{CB}$ & 166.9 & 22.9 & 2.6 & 3 & -0.1 & 2.8 & 0.5 & 2.3 \\
\hline & NB200 & 171.7 & 26.7 & 62.3 & 60.7 & 43.6 & 56.2 & 45.9 & 52.8 \\
\hline & NB350 & 165.9 & 26.1 & 95.1 & 70.1 & 134.4 & 56 & 129.4 & 58.8 \\
\hline & B350 & 189.3 & 41.8 & 34.8 & 51.3 & 23.9 & 40.7 & 18.7 & 35.8 \\
\hline \multirow{5}{*}{$\begin{array}{l}\mathrm{ML} \\
(\mu \mathrm{m} . v o l \%)\end{array}$} & CNB & 2822 & 727 & 181 & 174 & 766 & 231 & 182 & 244 \\
\hline & $\mathrm{CB}$ & 3036 & 1337 & 164 & 155 & 552 & 621 & 189 & 536 \\
\hline & NB200 & 4344 & 1788 & 950 & 1039 & 1264 & 1277 & 898 & 1404 \\
\hline & NB350 & 3370 & 1438 & 1305 & 944 & 2836 & 1940 & 2316 & 1739 \\
\hline & B350 & 4223 & 2294 & 566 & 683 & 637 & 892 & 157 & 889 \\
\hline
\end{tabular}

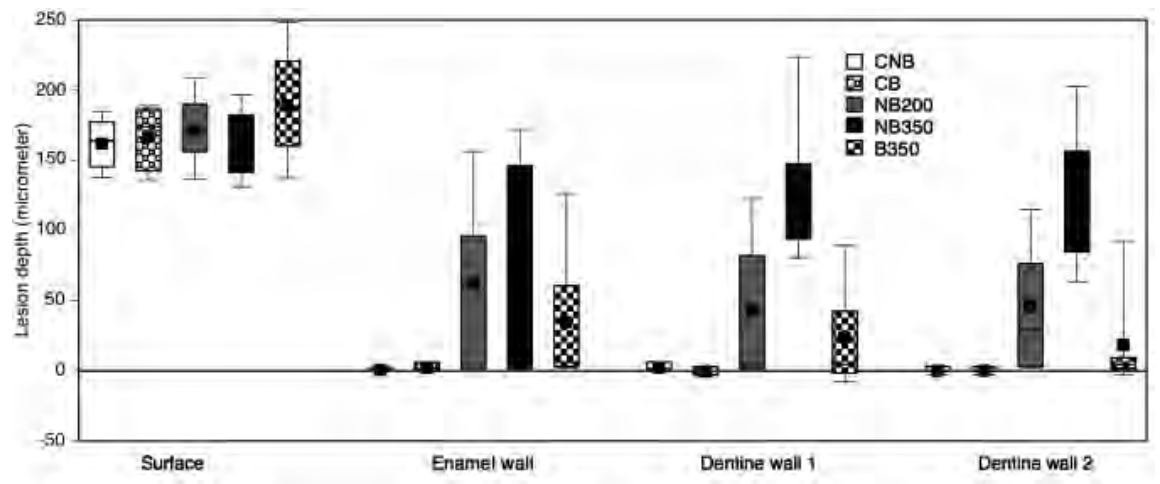

Figure 6.3 Box plots showing the lesion depth of each group at the different locations in enamel and dentin 
A statistically significant effect of the level of loading (comparing groups NB200 and NB350) could be observed for LD and ML only in the dentin (location WallDent1 LD $p=0.001, M L p=0.031$, and WallDent2 LD $p=0.002, M L p=0.042$ ), with a higher load leading to more advanced lesions.

The effect of bonding (comparing groups NB350 and B350) was also statistically significant for LD and ML at all wall locations (location WallEnam LD $p=0.034, \mathrm{ML}$ $\mathrm{p}=0.051$, WallDent1 LD $\mathrm{p}<0.001, \mathrm{ML} \mathrm{p}=0.002$, WallDent2 LD $\mathrm{p}<0.001, \mathrm{ML}$ $p=0.001$ ), with bonding leading to less advanced lesions.

\section{Discussion}

In this in vitro study, we found that, during mechanical loading, the level of load applied and the absence of adhesion were important factors in the development of artificial secondary caries wall lesions.

Since there was development of surface lesions in all groups, we can conclude that the model worked as a consistent caries model. Surface erosion was prevented by the addition of $0.5 \mathrm{ppm}$ fluoride to the demineralization solution. Moreover, the samples were covered with nail varnish on all sides, except half of the upper surface, so that the part of the surface lesion that would have been caused by erosion could be measured. No relevant surface erosion was observed.

There are some drawbacks of this model. Since, in this study, tooth samples had to have uniform and flat aligned enamel, due to the demands of the microradiographical method used, bovine instead of human teeth were used. Bovine teeth have been the most widely used substitute for human teeth in dental studies, but there are some concerns about the applicability, since their chemistry and structure are not identical. Yassen et al. (2011) reviewed all literature regarding whether bovine teeth can be considered as a appropriate substitute for human teeth, but no consensus could be reached, since the literature reviewed was inconsistent.

In this bacteria-free model, a lactid acid solution was used for development of caries. However, caries is a complicated bacterial disease and is caused by cariogenic plaque. This model does not take into account biofilm dynamics and other factors, such as host, genetic, and social factors. Because of the absence of a bacterial biofilm, both on the surface and in the gap, extrapolation to a clinical process is not possible. An in vitro microbial or in situ model including mechanical loading is required to approach the clinical situation more nearly.

We conducted this study to evaluate whether hydrodynamic flow through mechanical loading might play a role in the development of wall lesions. By 'hydrodynamic flow', we mean the movement of fluids through small openings (Brännström, 1986). We suspected that, if a tooth-restoration interface was not bonded, due to mechanical 
loading, the gap at the interface could be subjected to opening and closing forces, and therefore a hydrodynamic flow could be created. The results of comparison of the loaded groups NB350 and B350 show that absence of bonding is indeed a major factor in the development of wall lesions. Since none of the non-loaded samples, even those without bonding, developed wall lesions, it is likely that loading is also a factor in secondary caries development. Comparison of groups NB200 and NB350 confirms that loading force is a factor in secondary caries progression. The effect of loading force is much less noticeable in enamel wall lesions than in dentin wall lesions. We hypothesize that this is due to the higher solubility of dentin, resulting in an increased level of dissolution products in the fluid in the gap. As these products move toward the sample surface through diffusion and hydrodynamic flow, the degree of saturation at the enamel location is increased, reducing the rate of enamel dissolution.

Of 12 of the bonded samples in group B350, wall lesions developed in 3 samples. One explanation might be that the load of 350 grams actually broke the bond at the tooth-restoration interface in those samples. Once the bond was broken, these tooth-restoration interfaces were also subjected to hydrodynamic flow, accelerating the caries process. After the experiment, the 12 samples of group B350 were cut, and the cross-sectional view of the tooth-restoration interface was assessed under a microscope at 37.5 magnification. In the three samples with wall lesions, a gap between the tooth sample and the restoration could be observed. This is in agreement with the study by Staninec et al. (2008), who reported that specimens failed adhesively at the composite-dentin interface after cyclic loading in a four-point bending apparatus. The other nine samples showed no defects at the tooth-restoration interface.

Clinically, this puts more emphasis on the role of the bond at the tooth-restoration interface in secondary caries development, since most restorations will be clinically loaded. In this study, the degradation of the bond was caused by mechanical fatigue, but deterioration of this bond can also be caused by hydrolytic degradation.

In conclusion, in this in vitro study the level of loading and the absence of bonding were statistically significant factors in the development of artificial caries wall lesions. This supports the authors' hypothesis that mechanical loading in combination with a failed bond at the tooth-restoration interface creates a hydrodynamic flow that enhances secondary caries development.

\section{Acknowledgment}

The study was supported by the authors' institution. The authors declare no conflicts of interest with respect to the authorship and/or publication of this article. 


\section{References}

Bollet-Quivogne FR, Anderson P, Dowker SE, Elliott JC (2005). Scanning microradiographic study on the influence of diffusion in the external liquid on the rate of demineralization in hydroxyapatite aggregates. Eur J Oral Sci 113(1):53-59.

Brännström M (1986). The hydrodynamic theory of dentinal pain: sensation in preparations, caries, and the dentinal crack syndrome. J Endod 12(10):453-457.

Derand T, Birkhed D, Edwardsson S (1991). Secondary caries related to various marginal gaps around amalgam restorations in vitro. Swed Dent J 15(3):133-138

Francisconi LF, Graeff MS, Martins LM, Franco EB, Mondelli RF, Francisconi PA et al. (2009). The effects of occlusal loading on the margins of cervical restorations. J Am Dent Assoc 140(10):1275-1282.

Goldberg J, Tanzer J, Munster E, Amara J, Thal F, Birkhed D (1981). Cross-sectional clinical evaluation of recurrent enamel caries, restoration of marginal integrity, and oral hygiene status. J Am Dent Assoc 102(5):635-641.

Hodges DJ, Mangum FI, Ward MT (1995). Relationship between gap width and recurrent dental caries beneath occlusal margins of amalgam restorations. Community Dent Oral Epidemiol 23(4):200-204.

Jorgensen KD, Wakumoto S (1968). Occlusal amalgam fillings: marginal defects and secondary caries. Odontol Tidskr 76(1):43-54.

Kidd EA, Joyston-Bechal S, Beighton D (1995). Marginal ditching and staining as a predictor of secondary caries around amalgam restorations: a clinical and microbiological study. J Dent Res 74(5):1206-1211.

Kuper NK, Opdam NJ, Bronkhorst EM, Huysmans MC (2012). The influence of approximal restoration extension on the development of secondary caries. J Dent 40(3):241-247.

Qvist V (1983). The effect of mastication on marginal adaptation of composite restorations in vivo. J Dent Res 62(8):904-906.

Romeed SA, Malik R, Dunne SM (2012). Stress analysis of occlusal forces in canine teeth and their role in the development of non-carious cervical lesions: abfraction. Int J Dent 2012:234845.

Ruben J, Arends J, Christoffersen J (1999). The effect of window width on the demineralization of human dentin and enamel. Caries Res 33(3):214-219.

Silva AG, Martins CC, Zina LG, Moreira AN, Paiva SM, Pordeus IA, Magalhães CS (2012). The association between occlusal factors and noncarious cervical lesions: a systematic review.

J Dent 2012 Nov 8. pii: S0300-5712(12)00302-8. doi: 10.1016/j.jdent.2012.10.018. [Epub ahead of print].

Staninec M, Kim P, Marshall GW, Ritchie RO, Marshall SJ (2008). Fatigue of dentin-composite interfaces with four-point bend. Dent Mater 24(6):799-803

Thomann JM, Voegel JC, Gramain P (1990). Kinetics of dissolution of calcium hydroxyapatite powder. III: $\mathrm{pH}$ and sample conditioning effects. Calcif Tissue Int 46(2):121-129.

Thomas RZ, Ruben JL, de VJ, ten Bosch JJ, Huysmans MC (2006). Transversal wavelength-independent microradiography, a method for monitoring caries lesions over time, validated with transversal microradiography. Caries Res 40(4):281-291.

Thomas RZ, Ruben JL, ten Bosch JJ, Fidler V, Huysmans MC (2007). Approximal secondary caries lesion progression, a 20-week in situ study. Caries Res 41(5):399-405.

Totiam P, Gonzalez-Cabezas C, Fontana MR, Zero DT (2007). A new in vitro model to study the relationship of gap size and secondary caries. Caries Res 41(6):467-473.

Yassen GH, Platt JA, Hara AT (2011). Bovine teeth as substitute for human teeth in dental research: a review of literature. J Oral Sci 53(3):273-282. 



\section{7}

\section{General discussion}





\section{General discussion}

Although it is reported that more than half of the failing restorations are replaced due to secondary caries (Elderton, 1976), there are some specific diagnostic problems for secondary caries which may account for this high prevalence. As Kidd (1990) pointed out, the main specific diagnostic problems include the difficulty of detecting the wall lesion, the relevance of a defective margin to the longevity of a restoration and the difficulty of distinguishing secondary caries from residual caries. Secondary caries is defined as a lesion at the margin of an existing restoration (Kidd, 2001), but usually only the outer lesion can be detected visually. The wall lesion on the other hand cannot be seen until it is so advanced that the overlying tissue collapses, the tooth tissue becomes grossly discolored or it is detected by radiography. But discoloration around restorations can be caused by a variety of factors such as the physical presence of residual amalgam, corrosion products, microleakage or secondary caries. Stained restoration margins are not always indicative for the presence of secondary caries (Kidd et al., 1995).

In general dental practice $50-60 \%$ of restorations are replaced due to the diagnosis of secondary caries (Mjör and Toffenetti, 2000). However, this high prevalence is not found in controlled clinical trials, in which it varies between 4 and $16 \%$ of the failing restorations (Goldberg et al., 1981; Hewlett et al., 1993; Letzel et al., 1997). This discrepancy can be explained in two ways. One explanation might be that dentists in general dental practice consider a restoration with a discolored margin as a restoration with secondary caries and replace it unnecessarily. The other explanation might be that in clinical trials conditions are optimal and caries risk of the study population is low, which is not representative of general dental practice.

Gaps and other marginal defects are a commonly used criterion for replacing restorations by dentists. This is rationalized by the hypothesis that wall lesions might be caused by microleakage, mainly based on the results of in vitro studies. However, caries is a disease determined by the dynamic balance between pathological factors that lead to demineralization and protective factors that lead to remineralization. Therefore, the presence of a gap might be a risk factor for plaque stagnation, but is not a sufficient factor to determine the development of secondary caries.

\section{The relevance of gap size in secondary caries development}

A considerable amount of research has been focused on how large gaps between restoration and tooth should be, to be susceptible to secondary caries development. Investigating the relevance of gap size at the smallest level, there are mainly in vitro studies focusing on the quality of the adhesive bond between tooth and restoration by performing microleakage tests. Microleakage refers to the clinically undetectable leakage between the cavity wall and the filling (Kidd, 1976). The conclusions that can 
be drawn based on these microleakage tests are limited. Firstly, it is questioned whether such in vitro experiments will predict the behavior of restorations under clinical circumstances accurately. In the study of Abdalla and Davidson (1993) the marginal integrity of in vivo and in vitro Class II composite restorations was compared. It was found that microleakage was observed in all the in vivo specimens with only $60 \%$ of the in vitro specimens demonstrating microleakage. These results indicate the limitation of laboratory investigations regarding microleakage. Secondly, it is questioned how clinically relevant microleakage is. Heintze (2007) carried out a systematic review investigating the correlation between clinical performance and microleakage in vitro of restorations and was not able to show any correlation. Therefore, the value of microleakage tests is disputed.

Another preconception of dentists, based on microleakage tests, is that the performance of subgingival (composite) restorations is less than that of supragingival restorations due to occurrence of secondary caries. Dye penetration studies performed on Class II resin-composite restorations have, over time, consistently shown that restorations with margins placed above the CEJ performed better than those with margins placed below the CEJ (Lui et al., 1987; Hembree, 1989; Prati, 1989; Beznos, 2001; Demarco et al., 2001; Tredwin et al., 2005; Araujo de et al., 2006). However, in our clinical study (Chapter 2) we could not show higher secondary caries incidence with sub CEJ restorations than with supra CEJ restorations. In our in situ study (Chapter 5) we also showed that microleakage was not relevant in secondary caries development. None of the 24 samples restored with resin composite material but without any adhesive showed secondary caries formation along the tooth-restoration interface. However, the marginal integrity of resin composite restorations has been reported to be influenced by the functional stresses caused by mastication (Qvist, 1983), and in our in vitro study (Chapter 6) we showed that samples with a failed bond, which are probably exposed to more microleakage, in combination with occlusal loading, developed secondary caries along the interface. Wall lesions developed in all non-bonded specimens which were loaded, whereas only 3 out of 12 bonded and loaded specimens showed wall lesions. It was suspected that in the 3 bonded specimens with wall lesion development the adhesive bond was broken as it only occurred in the group with the highest loading (350 grams vs. 200 grams).

\section{The influence of gap size on secondary caries development}

Irie et al. (2002) found that even after using an acid etch and a bonding agent during restorative procedure, a gap of 6-10 $\mu \mathrm{m}$ formed immediately at the tooth-restoration interface. As we observed no secondary caries in bonded interfaces without loading (Chapter 5 and 6), we hypothesized that gaps needed to be larger than $10 \mu \mathrm{m}$ in order to enable secondary caries development. Over time, research has been carried out to find out whether gap size is relevant for secondary caries formation and what 
the minimum threshold for a clinical relevant gap size would be. Up till now, there has been no conclusive statement about the relationship between gap size and secondary caries.

Several studies have shown a positive relationship. In 1968 Jørgensen and Wakumoto reported a positive correlation between the size of marginal defects and the development of secondary caries. In this in vivo study lower first permanent molars were extracted for orthodontic purposes and the amalgam restorations in these teeth were examined for the degree of deterioration and the presence of secondary caries. The study population consisted of children (age 9-15 years) with relatively high caries activity. The results showed that the increase in likelihood of secondary caries with the increasing size of the marginal defect was apparent. There were no secondary carious lesions associated with defects under $50 \mu \mathrm{m}$ in size.

The cross-sectional study of Goldberg et al. (1981) studied the relationship among secondary caries, size of the marginal defect and oral hygiene status in 87 volunteers (age 17-61 years). Marginal quality of 1556 restorations was scored and oral hygiene status was measured by plaque and gingival indices. Their results also showed that there was an increasing likelihood of secondary caries with increasing size of the marginal gap. However, it was also shown that oral hygiene played a significant role in determining the likelihood of secondary caries.

Dérand et al. (1991) investigated the relationship between the amalgam-tooth gap and the presence of secondary caries with an in vitro model. Dentin-enamel blocks, cut from human cariesfree molars, were placed in an apparatus which allowed an amalgam restoration block to be placed with a controlled gap size. Gap widths varied from $0,30,40,60$, and $80 \mu \mathrm{m}$. Caries lesions were induced by inoculation with S. Mutans in sucrose- and glucose-supplemented culture media. Dentin caries was found in all of the specimens cultured in the sucrose medium when a gap of $30 \mu \mathrm{m}$ or more was present. In the glucose group, dentin caries was present only for the largest gap width of 60 and $80 \mu \mathrm{m}$. These results support the concept of a threshold gap size for initiation of secondary caries. Totiam et al. (2007) compared specimens restored with composite and a gap size of $50 \mu \mathrm{m}$ and $500 \mu \mathrm{m}$ in an in vitro microbial caries model (S. Mutans, 1\% sucrose) in a first experiment and found a trend of bigger wall lesions associated with bigger gap groups in enamel and dentin, but a significant effect was only found in the dentin. In a second experiment gap sizes of 0 , 25, 250 and $1000 \mu \mathrm{m}$ were compared and also now a trend was found for bigger wall lesions associated with bigger gaps. However, in the enamel only between 0 vs. 1000 $\mu \mathrm{m}$ and 25 vs. $1000 \mu \mathrm{m}$ a statistically significant difference could be found (no significance for 0-25 $\mu \mathrm{m}, 25-250 \mu \mathrm{m}, 250-1000 \mu \mathrm{m}$ ) and in the dentin only between the groups 25-250 $\mu \mathrm{m}, 25-1000 \mu \mathrm{m}, 250-1000 \mu \mathrm{m}$ (no significance for 0-25 $\mu \mathrm{m}$ ). The conclusion we can draw from these results is that differences in gap size have to be quite substantial (several hundreds of microns) to influence wall lesion development. 
In the clinical study of Hodges et al. (1995) amalgam restorations were removed solely because of defective margins and the clinically detected gap was recorded by making an impression. Upon removal of the restoration, the presence of secondary caries was noted. The mean gap widths of secondary carious sites and non-carious sites were compared within the same tooth. A statistically significant difference of 187 $\mu \mathrm{m}$ was found between the mean gap width of secondary caries sites and non-carious sites, with the secondary caries gaps being wider.

In the bacterial based in vitro study of Diercke et al. (2009) it was shown that wall lesions can develop without the presence of outer lesions and that the extent of the independently developed wall lesions also increased with gap width. In enamel a significant increase in wall lesion area was found between $50 \mu \mathrm{m}$ and $250 \mu \mathrm{m}$ gap widths and in dentin between $50 \mu \mathrm{m}$ and $100 \mu \mathrm{m}$.

On the other hand there are also studies that could not find any relationship between gap presence and secondary caries. Kidd and O'Hara (1990) found in sectioned, extracted teeth that $54 \%$ of the amalgam restorations had carious lesions in the enamel of the cavity wall, regardless of the margin being defective or sound. Pimenta et al. (1995) carried out a similar study and found caries in $47 \%$ of margins without defects and found caries in $58 \%$ of ditched margins, which is not a statistically significant difference.

In sum up, from all the research described above it is not possible to draw one straightforward conclusion on the relationship of the gap size and secondary caries. Even in this thesis we found conflicting results. In our in vitro biofilm model study (Chapter 3) we did find that gap size influenced the wall lesion depth in dentin, but in our in situ study (Chapter 5) we did not find a clear trend for increasing lesion progression with wider gaps.

Once again, the etiology of secondary caries is complex and just focusing on the correlation of gap size with secondary caries may be an oversimplification. Other factors that could influence the secondary caries process and how methodology affects the outcome on secondary caries research will be discussed later.

\section{Restorative materials}

Even though the scientific evidence is still limited, it is assumed that composite restorations fail more often due to secondary caries than amalgam restorations. A good marginal seal is seen as a protection against secondary caries as these lesions develop along the tooth-restoration interface. As the marginal sealing ability of composite is better than the sealing ability of amalgam it is really paradoxical that composite shows more secondary caries as a failure reason than amalgam. The possible explanation for this would be that the composite contains components, possibly leaking out, which promote cariogenic biofilm development or that the surface properties of composite enable easier biofilm adherence. It is also 
thought that corrosion products of amalgam seal the gap at the tooth-restoration interface.

In this thesis we compared several composite materials with amalgam regarding secondary caries development. Clearfil AP-X composite is a methacrylate based composite, while Filtek Silorane, deriving from oxirane and siloxane, is a silica-expoxy based material. We compared these two composites, as Filtek Silorane was developed as a low-shrinkage composite material and is thought to show less secondary caries development due to less gap formation. However, in our study (Chapter 3) the restoration blocks were made indirectly and therefore there was no possible advantage of the lower shrinkage of Filtek Silorane. This might explain why we didn't find any differences in lesion development between Clearfil AP-X, Filtek Silorane and Tytin Amalgam in vitro. We did find a significant difference for composites covered with a bonding agent with the antibacterial monomer MDPB (Protect Bond), leading to less caries progression compared to bare composite materials. This anti-caries effect was also found in the in situ study of van de Sande et al. (2014). However, the duration of both studies was only several weeks ( 3 weeks and 8 weeks) and it is possible that under clinical conditions the anti-caries effect of the MDPB does not last very long. Amalgam, on the other hand, had a disadvantage in anti-caries effect in these studies as corrosive products, which are believed to contribute to the cariostatic properties, do not form in a three- or eight week period.

In our in situ study regarding gap size (Chapter 5) Filtek Supreme composite was compared with Clearfil AP-X composite. Filtek Supreme is a nanofilled composite and AP-X is a microhybrid composite, both composites are metacrylate based. The use of smaller inorganic fillers in nanocomposites are thought to have lower surface roughness (de Moraes et al., 2009) and might therefore show less secondary caries. In our in situ study (Chapter 5) we could not find a statically significant difference between Filtek Supreme and Clearfil AP-X. However, in our in situ study in which we compared both composites with amalgam (Chapter 4), we did find that AP-X composite showed statistically more mineral loss than amalgam, whereas between Filtek Supreme composite and amalgam no difference could be found. This does suggest that Filtek Supreme, to some degree, may have more favorable properties regarding secondary caries than AP-X composite.

\section{Study design}

The oral cavity is extremely complex and difficult to simulate. The various models and methodologies (in vitro, in situ or in vivo) available, each have their advantages and disadvantages in investigating secondary caries. In this thesis, we carried out a practice based clinical study (Chapter 2), an in situ study (Chapter 4 and 5), a bacterial in vitro study (Chapter 3) and a non-bacterial in vitro study (Chapter 6). The results of the in situ study and the bacterial in vitro study were conflicting regarding whether 
gap size significantly influences the secondary caries lesion progression. In the in situ study (Chapter 5) we did not and in the in vitro biofilm model (Chapter 3) we did find an effect of gap size. These different findings might be due to the differences in models and methodologies. In the in vitro biofilm study the saliva of only one person was used as the inoculum, whereas in the in situ study 14 volunteers participated and therefore there was much more interpersonal variation. Persons have varying degrees of susceptibility to caries and this was also shown in our in situ study. Despite the highly standardized cariogenic exposure, there were still volunteers with very little caries development, whereas others had abundant caries development. We hypothesized that in the in situ study the patient's susceptibility to caries may have obscured the effect of gap size.

We also observed a difference in the shape and progression of wall lesions among our different studies. The explanation for these differences in wall lesions could lie within the gap geometry and the tooth substrate (human/bovine, enamel-dentin or solely dentin) used.

In the in situ study (Chapter 5) the shape of wall lesions was in most of the samples of equal width, parallel to the gap interface, extending up to full height of the samples/gap depth, see Figure 7.1. In the non bacterial in vitro study (Chapter 6) in which non bonded specimens were loaded, the shape of the wall lesion was gradient and also extending up to the full height of the sample, see Figure 7.2. In the enamel-dentin samples of the in vitro biofilm study (Chapter 3 ) the shape of the wall lesions was not gradient, but more curved (at least in the dentin) and in most specimens the wall lesion covered only a small part of the height of the sample (approximately a third of the height of the samples/ gap depth), see Figure $7.3 \mathrm{a}$ and b.

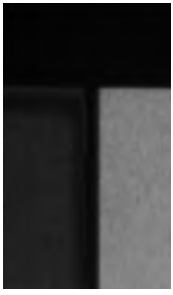

Figure 7.1

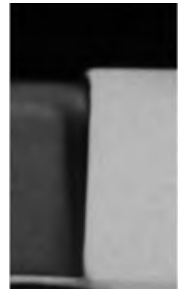

Figure 7.2

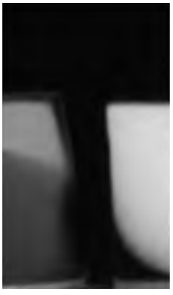

Figure 7.3a

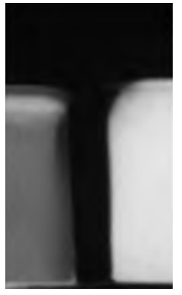

Figure $7.3 b$

We think that the differences in extent of the wall lesions along the interface in the two in vitro studies, see Figure 7.2 and 7.3b, can be explained by the presence of the hydrodynamic flow in the non bacterial in vitro study. Even though the gaps of the non bacterial in vitro study (Chapter 6) were much smaller (estimated around $10 \mu \mathrm{m}$ as the samples were restored, but not bonded), see Figure 7.2, the wall lesions extended 
up to the full height of the samples. In the bacterial in vitro study (Chapter 3 ) the gaps were much larger, around 300-400 $\mu \mathrm{m}$, but the extension of the wall lesions down the gap was much smaller, see Figure 7.3b. We hypothesized that due to the loading of the samples in the non-bacterial study, the gap was subjected to cycles of opening and closing forces which led to fluid movement in and out of the gap. Due to the hydrodynamic flow the full length/height of the samples was demineralized as the diffusion products were moved along the full interface.

There were also differences between the development of wall lesions in enamel and in dentin. The wall lesion was always at widest just beneath the enamel-dentin junction, see Figure 7.2 and Figure 7.3. This is probably due to the effect that when dentin and enamel are demineralizing in close proximity, the dentin, which is more soluble, provides the surrounding fluid with dissolution products, which reduces the dissolution of the enamel by raising the saturation level (Lynch and Ten Cate, 2006). As enamel therefore demineralizes slower, effects of other factors, for instance loading or gap size, were less prominent than in dentin.

In this thesis, we experienced that wall lesions formed in dentin-enamel blocks (instead of solely dentin or enamel), mimic the progression and shape of wall lesions formed in clinical conditions most. In both in vitro studies we used dentin-enamel samples, however, those were cut from bovine and not human teeth. Reason for this was that preparing straight aligned block samples from human teeth, needed for the T-WIM technique used, was not feasible. Bovine teeth have the advantage over human teeth that they have a large and flat area of enamel and dentin of which blocks are easily cut. Human molars have round surfaces and the enamel is never ideally positioned in line with the dentin, causing overlap in dentin and enamel on the T-WIM pictures resulting in blurred images.

As much as we would like to investigate secondary development in gaps under clinical conditions, it is impossible. Creating standardized sized gaps in vitro was already a challenge and provoking secondary caries in patients are accompanied with severe medical-ethical objections. Therefore, in situ studies remain our best option to approximate clinical conditions.

\section{Intra-oral factors}

From caries research, we know that several intra-oral factors can predict and/or influence the disease progression. Examples of those factors are oral hygiene status, diet, caries history, biochemistry of the saliva and oral flora, all together determining the patient's caries risk factor. In the in situ study we carried out we had to deal with some of these factors, but in the in vitro studies those factors played no role. Therefore, we will only discuss the intra-oral factors that were present in our in situ study.

In the in situ study (Chapter 4 and 5) volunteers were asked to sustain from any oral hygiene (tooth brushing and cleaning) regarding the samples in the device, so 
this factor, normally assumed to be one of the most important factors in predicting caries development clinically, was consistent throughout all volunteers. As all volunteers dipped their samples 8 times a day in a 20\% sucrose solution, also the diet was highly cariogenic. However, despite two of the main and clinically most important factors being equal among volunteers, we still observed a variety in degree of caries development. There were patients with great caries lesions, but others, within the same protocol, showed hardly any/little caries lesions.

There must have been other factors that had their impact on caries development in this study. One factor, which we did not investigate in this study and could account for some of the differences in caries development, is the different biochemistry of the saliva and oral clearance of each volunteer. Another known variable in the caries process is the constitution of the biofilm. Higher numbers of Streptococcus Mutans and Lactobacilli are found in caries active patients (Zickert et al., 1983). Plaque samples from each gap of all the volunteers were sampled and will be analyzed with pyrosequencing technique. It will be very interesting to compare the biofilm composition from these gaps with the biofilm composition of surface lesions in primary caries. It will also be of value to know whether the biofilm make up in the smaller gaps differed from the biofilm make up in the wider gaps.

Caries was always seen as mainly a behavioral disease, but with these new insights we might have to approach this differently now. A patient's caries risk is not only influenced by oral hygiene and cariogenic diet, and it might be a sum up of several different intra-oral factors that in total can lead to secondary caries development. An explanation why patients with similar behavior risk, have different caries risk, might lay in genetic predisposition (Bretz et al., 2003). A combination of candidate gene and genome wide studies has been published with some evidence that genetic factors are influencing the individual susceptibility to caries, but also showing the difficulties of developing a study with robust phenotype definitions and sample sizes that allow enough statistical power to detect genetic effects (Vieira et al., 2014). The most compelling early evidence for a genetic component to caries comes from studies of twins reared apart. In two related studies, investigators found significant resemblance for percentages of teeth and surfaces restored or carious within monozygotic but not dizygotic twin pairs reared apart and estimated the genetic contribution to caries as 40\% (Boraas et al., 1988; Conry et al., 1993).

Clinically, this means, when dentists are considering to replace restorations with marginal defects, these above described (risk) factors should be taken into account carefully, before replacing restorations unnecessarily. 


\section{Conclusions of this thesis}

Restorative materials and secondary caries

- In vitro amalgam did not show reduced secondary caries progression in dentin compared to composite materials

- $\quad$ AP-X composite with Protect Bond showed significantly less caries progression in vitro compared to bare restorative materials or other adhesives.

- In situ composite showed wall lesions with statistically significant more mineral loss than amalgam.

Relationship between gap width and wall lesions

- $\quad$ The gap size needed for wall lesions to develop is much smaller than we originally thought. The smallest gap size measured in our in situ study, in which a wall lesion developed, was $68 \mu \mathrm{m}$.

- $\quad$ In situ we did not find that smaller gaps led to smaller wall lesions, but in vitro we did find an effect of gap size with smaller gaps leading to less advanced wall lesions.

Loading and secondary caries development

- $\quad$ Our in vitro study showed that loading of restorations which are debonded, can lead to faster progression of secondary caries lesions due to hydrodynamic flow.

Microleakage and secondary caries development

- $\quad$ Restorations with margins extending below the CEJ, and thus probably exposed to more microleakage, do not fail more often due to secondary caries. 


\section{References}

Abdalla AI, Davidson CL (1993). Comparison of the marginal integrity of in vivo and in vitro Class II composite restorations. Journal of dentistry 21(3):158-162.

Araujo de O, Vieira LC, Monteiro Junior S (2006). Influence of resin composite shade and location of the gingival margin on the microleakage of posterior restorations. Operative dentistry 31(5):556-561.

Beznos C (2001). Microleakage at the cervical margin of composite Class II cavities with different restorative techniques. Operative dentistry 26(1):60-69.

Boraas JC, Messer LB, Till MJ (1988). A genetic contribution to dental caries, occlusion, and morphology as demonstrated by twins reared apart. Journal of dental research 67(9):1150-1155.

Bretz WA, Corby P, Schork N, Hart TC (2003). Evidence of a contribution of genetic factors to dental caries risk. The journal of evidence-based dental practice 3(4):185-189.

Conry JP, Messer LB, Boraas JC, Aeppli DP, Bouchard TJ, Jr. (1993). Dental caries and treatment characteristics in human twins reared apart. Archives of oral biology 38(11):937-943.

de Moraes RR, Goncalves Lde S, Lancellotti AC, Consani S, Correr-Sobrinho L, Sinhoreti MA (2009). Nanohybrid resin composites: nanofiller loaded materials or traditional microhybrid resins? Operative dentistry 34(5):551-557.

Demarco FF, Ramos OL, Mota CS, Formolo E, Justino LM (2001). Influence of different restorative techniques on microleakage in Class II cavities with gingival wall in cementum. Operative dentistry 26(3):253-259.

Dérand T, Birkhed D, Edwardsson S (1991). Secondary caries related to various marginal gaps around amalgam restorations in vitro. Swedish dental journal 15(3):133-138.

Diercke K, Lussi A, Kersten T, Seemann R (2009). Isolated development of inner (wall) caries like lesions in a bacterial-based in vitro model. Clinical oral investigations 13(4):439-444.

Elderton RJ (1976). The causes of failure of restorations: a literature review. Journal of dentistry 4(6):257-262.

Goldberg J, Tanzer J, Munster E, Amara J, Thal F, Birkhed D (1981). Cross-sectional clinical evaluation of recurrent enamel caries, restoration of marginal integrity, and oral hygiene status. Journal of the American Dental Association 102(5):635-641.

Heintze SD (2007). Systematic reviews: I. The correlation between laboratory tests on marginal quality and bond strength. II. The correlation between marginal quality and clinical outcome. The journal of adhesive dentistry 9 Suppl 1:77-106.

Hembree JH, Jr. (1989). Microleakage at the gingival margin of class II composite restorations with glass-ionomer liner. The Journal of prosthetic dentistry 61(1):28-30.

Hewlett ER, Atchison KA, White SC, Flack V (1993). Radiographic secondary caries prevalence in teeth with clinically defective restorations. Journal of dental research 72(12):1604-1608.

Hodges DJ, Mangum FI, Ward MT (1995). Relationship between gap width and recurrent dental caries beneath occlusal margins of amalgam restorations. Community dentistry and oral epidemiology 23(4):200-204.

Irie M, Suzuki K, Watts DC (2002). Marginal gap formation of light-activated restorative materials: effects of immediate setting shrinkage and bond strength. Dental materials : official publication of the Academy of Dental Materials 18(3):203-210.

Jørgensen KD, Wakumoto S (1968). Occlusal amalgam fillings: marginal defects and secondary caries. Odontologisk tidskrift 76(1):43-54.

Kidd EA (1976). Microleakage: a review. Journal of dentistry 4(5):199-206.

Kidd EA (1990). Caries diagnosis within restored teeth. Advances in dental research 4:10-13.

Kidd EA, O'Hara JW (1990). The caries status of occlusal amalgam restorations with marginal defects. Journal of dental research 69(6):1275-1277.

Kidd EA, Joyston-Bechal S, Beighton D (1995). Marginal ditching and staining as a predictor of secondary caries around amalgam restorations: a clinical and microbiological study. Journal of dental research 74(5):1206-1211.

Kidd EA (2001). Diagnosis of secondary caries. Journal of dental education 65(10):997-1000.

Kuper NK, Opdam NJ, Bronkhorst EM, Huysmans MC (2012). The influence of approximal restoration extension on the development of secondary caries. Journal of dentistry 40(3):241-247. 
Kuper NK, Opdam NJ, Bronkhorst EM, Ruben JL, Huysmans MC (2013). Hydrodynamic flow through loading and in vitro secondary caries development. Journal of dental research 92(4):383-387.

Kuper NK, Opdam NJ, Ruben JL, de Soet JJ, Cenci MS, Bronkhorst EM et al. (2014). Gap Size and Wall Lesion Development Next to Composite. Journal of dental research 93(7 suppl):108S-113S.

Kuper NK, van de Sande FH, Opdam NJ, Bronkhorst EM, de Soet JJ, Cenci MS et al. (2015). Restoration Materials and Secondary Caries Using an In Vitro Biofilm Model. Journal of dental research 94(1):62-68.

Letzel H, van 't Hof MA, Marshall GW, Marshall SJ (1997). The influence of the amalgam alloy on the survival of amalgam restorations: a secondary analysis of multiple controlled clinical trials. Journal of dental research 76(11):1787-1798.

Lui JL, Masutani S, Setcos JC, Lutz F, Swartz ML, Phillips RW (1987). Margin quality and microleakage of Class II composite resin restorations. Journal of the American Dental Association 114(1):49-54.

Lynch RJ, Ten Cate JM (2006). The effect of adjacent dentine blocks on the demineralisation and remineralisation of enamel in vitro. Caries research 40(1):38-42.

Mjör IA, Toffenetti F (2000). Secondary caries: a literature review with case reports. Quintessence international 31(3):165-179.

Pimenta LA, Navarro MF, Consolaro A (1995). Secondary caries around amalgam restorations. The Journal of prosthetic dentistry 74(3):219-222.

Prati C (1989). Early marginal microleakage in Class II resin composite restorations. Dental materials : official publication of the Academy of Dental Materials 5(6):392-398.

Qvist V (1983). The effect of mastication on marginal adaptation of composite restorations in vivo. Journal of dental research 62(8):904-906.

Totiam P, Gonzalez-Cabezas C, Fontana MR, Zero DT (2007). A new in vitro model to study the relationship of gap size and secondary caries. Caries research 41(6):467-473.

Tredwin CJ, Stokes A, Moles DR (2005). Influence of flowable liner and margin location on microleakage of conventional and packable class II resin composites. Operative dentistry 30(1):32-38

van de Sande FH, Opdam NJ, Truin GJ, Bronkhorst EM, de Soet JJ, Cenci MS et al. (2014). The influence of different restorative materials on secondary caries development in situ. Journal of dentistry 42(9):11711177.

Vieira AR, Modesto A, Marazita ML (2014). Caries: review of human genetics research. Caries research 48(5):491-506.

Zickert I, Emilson CG, Krasse B (1983). Correlation of level and duration of Streptococcus mutans infection with incidence of dental caries. Infection and immunity 39(2):982-985. 

8

Summary 



\section{Summary}

The main objective of this thesis was to investigate the influence of gaps and their size on the development of secondary caries. Secondary caries is one of the reasons most frequently reported in relation to failure and replacement of restorations. In order to understand the etiology better, we investigated whether gaps and what size of gaps contribute to the secondary caries process.

In this thesis we carried out a practice based clinical study (Chapter 2) to investigate whether the cervical extension of the restoration influenced the failure of restorations due to secondary caries. The influence of gap size was investigated in an in situ study (Chapter 5) and in an in vitro study (Chapter 3). In the same in situ study (Chapter 4 and 5) and in vitro study (Chapter 3) we also investigated whether different restorative materials influenced the secondary caries process. Finally, we explored in vitro (Chapter 6) whether loading of restorations, in combination with a failed adhesive bond, could promote secondary caries development.

Chapter 1 describes the etiology and histology of secondary caries and gives an overview of the many factors that could influence the secondary caries process. Different caries models, which are applied to study the caries process, are discussed.

The practice based clinical study in Chapter 2 evaluated whether occlusoproximal restorations with cervical margins apical to the cement-enamel junction (CEJ) are more prone to failure than restorations with margins coronal to the CEJ, in particular failure due to secondary caries. Cervical margin extension was scored on bitewings, and validated in vitro. Records from 84 patients with at least one occlusoproximal restoration replaced due to secondary caries were selected from an existing database. Cervical margins of approximal restoration sites were scored on bitewings in relation to the CEJ (supra vs. sub CEJ). For all restorations dates of placement, replacement and reason for failure were recorded. Survival times were calculated and Cox-regression analysis was applied to assess the influence of cervical margin extension and other variables. In total 1912 restorations sites were examined of which 655 failed; 399 supra CEJ and 256 sub CEJ. 257 restorations failed because of secondary caries. Restorations with cervical margins apical to the CEJ did not fail more often due to secondary caries. However, those restorations did show larger risk of failure overall compared to restorations with margins coronal to the CEJ. Resin composite restorations showed increased risk for secondary caries compared to amalgam restorations.

In Chapter $\mathbf{3}$ an in vitro study is described that investigated whether restoration materials and adhesives influence secondary caries formation in gaps. In a short 
term in vitro biofilm model sixty enamel-dentin blocks, restored with 6 different restoration materials with or without adhesives with a gap, were tested. Restorative materials and adhesives evaluated were: 1) Clearfil AP-X composite, 2) Clearfil AP-X composite + SE Bond, 3) Clearfil AP-X composite + Protect Bond, 4) Filtek Silorane composite, 5) Filtek Silorane composite + Silorane System adhesive, and 6) Tytin amalgam. Specimens were subjected to an intermittent $1 \%$ sucrose biofilm model for 20 days to create artificial caries lesions. Lesion progression in the enamel-dentin next to the different materials was measured using Transversal Wavelength Independent Microradiography (T-WIM). Amalgam did not show reduced secondary caries progression in dentin compared with composite materials. Also, there was no significant difference for caries development among different composite materials. AP-X composite with Protect Bond, however, showed significantly less caries progression compared with bare restoration materials or other adhesives.

In the in situ study of Chapter 4 secondary caries development in dentin in gaps next to composite and amalgam was compared. For 21 days, 14 volunteers wore a modified occlusal splint containing human dentin samples with an average gap of $215 \mu \mathrm{m}(\mathrm{sd}=55 \mu \mathrm{m})$ restored with three different materials: Filtek Supreme composite, Clearfil AP-X composite and Tytin amalgam. Eight times a day, the splint with samples was dipped in a $20 \%$ sucrose solution for 10 minutes. Before and after caries development, specimens were imaged with Transversal Wavelength Independent Microradiography (T-WIM), and lesion depth (LD) and mineral loss (ML) were calculated. The LD and ML of the three restoration materials were compared within patients using paired t-tests. AP-X composite showed the highest LD and ML. Amalgam showed statistically significantly less $\mathrm{ML}(\Delta=452 \mu \mathrm{m} . \mathrm{vol} \%)$ than the combined composite materials $(p=0.01$ ). When comparing amalgam to the separate composite materials, only AP-X composite showed higher ML $(\Delta=515 \mu \mathrm{m} \cdot \mathrm{vol} \%)$ than amalgam $(p=0.034)$. Analysis of LD showed the same trends, but these were not statistically significant.

The in situ study of Chapter 5 investigated whether there is a relationship between gap size and wall lesion development in dentin next to two composite materials, and whether a clinically relevant threshold for the gap size could be established. For 21 days, 14 volunteers wore a modified occlusal splint containing human dentin samples with 5 different interfaces: 4 gaps of $50 \mu \mathrm{m}, 100 \mu \mathrm{m}, 200 \mu \mathrm{m}$, or $400 \mu \mathrm{m}$ and 1 non-bonded interface without a gap. Before and after caries development, specimens were imaged with Transversal Wavelength Independent Microradiography (T-WIM), and lesion depth (LD) and mineral loss (ML) were calculated at the 5 different interfaces. No relationship could be found between gap size and wall lesion development. A minimum gap size could not be established, although, in a 
non-bonded interface without a measurable gap, wall lesion development was never observed.

In Chapter 6 the effect of hydrodynamic flow through mechanical loading on the development of secondary caries lesions was investigated in vitro. Forty-eight bovine tooth specimens (enamel and dentin) were restored with resin composite on polystyrene bars; 18 samples were bonded, and 30 were not bonded. Specimens were suspended in a lactic acid solution $(\mathrm{pH}=5)$ during 14 days in a modified brushing machine, and artificial caries lesions were formed. During caries development, specimens were mechanically loaded at the surface of the polystyrene bar, in such a way that the tooth-composite interfaces were subjected to opening forces (16x/min). Loads applied were either none (control group, bonded CB or non bonded CNB), 200 gram (group NB200), or 350 gram (NB350 and B350). Before and after caries development, specimens were imaged with Transversal Wavelength Independent Microradiography (T-WIM), and lesion depth (LD) and mineral loss (ML) were calculated at 4 different locations. The level of loading and the presence of bonding were statistically significant factors in the development of artificial caries wall lesions. A higher load and absence of bonding led to more advanced lesions, which supports the hypothesis that mechanical loading in combination with a failed bond at the tooth-restoration interface creates a hydrodynamic flow that enhances secondary caries development.

Finally, in Chapter 7 the available literature on secondary caries and gaps is discussed. The strengths and limitations of the different methodologies used in this thesis, are discussed. Based on this thesis we conclude that the development of secondary caries is influenced by many factors and that the presence of a gap is only one of them and that the influence of the size of the gap is still under discussion. 



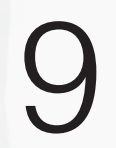

\title{
Samenvatting
}

\author{
Dankwoord
}

Curriculum Vitae 



\section{Samenvatting}

De belangrijkste doelstelling van dit proefschrift was om de invloed van randspleten en hun grootte, op de ontwikkeling van secundaire cariës te onderzoeken. Secundaire cariës is een van de meest voorkomende redenen waardoor restauraties falen en vervangen worden. Om de etiologie beter te begrijpen, hebben we onderzocht of randspleten en welke grootte randspleten bijdragen aan het ontstaan van secundaire cariës.

In dit proefschrift hebben we een practice based klinische studie (Hoofdstuk 2) uitgevoerd om te onderzoeken of de cervicale extensie van restauraties invloed heeft op het falen van restauraties ten gevolge van secundaire cariës. De invloed van de randspleet werd onderzocht in een in situ studie (Hoofdstuk 5) en in een in vitro studie (Hoofdstuk 3). In dezelfde in situ studie (Hoofdstuk 4 en 5) en in vitro studie (Hoofdstuk 3) hebben we ook onderzocht of verschillende restauratiematerialen het secundaire cariës proces beïnvloeden. Tenslotte hebben we in vitro (Hoofdstuk 6) gekeken of belasting van restauraties, waarvan de hechting niet optimaal was, de ontwikkeling van secundaire cariës kon bevorderen.

Hoofdstuk 1 beschrijft de etiologie en histologie van secundaire cariës en geeft een overzicht van de vele factoren die het secundaire cariësproces zouden kunnen beïnvloeden. Verschillende cariës modellen, die gebruikt worden om het cariësproces te bestuderen, worden besproken.

De practice based klinische studie in Hoofdstuk 2 onderzocht of approximale restauraties met een cervicale outline apicaal ten opzichte van de glazuurcementgrens (GCG), vaker faalden dan restauraties met een cervicale outline coronaal ten opzicht van de GCG, met name op het gebied van secundaire cariës. De cervicale outline werd gescoord op bitewings en gevalideerd in vitro. Patiëntgegevens van 84 patiënten waarbij op zijn minst één approximale restauratie vervangen was vanwege secundaire cariës, werden geselecteerd uit een bestaande database. Van alle restauraties werd de datum van vervaardiging, vervangen en reden van falen vastgelegd. De overlevingsduur werd berekend en een Cox-regressie analyse werd uitgevoerd om de invloed van de restauratie outline en andere variabelen te beoordelen. In totaal werden 1912 restauratievlakken beoordeeld, waarvan er 655 faalden; 399 boven de GCG en 256 onder de GCG. 257 restauraties faalden door secundaire cariës. Restauraties met een cervicale outline apicaal ten opzichte van de GCG faalden niet vaker wegens secundaire cariës. Deze restauraties faalden echter in het algemeen wel vaker dan restauraties met een cervicale outline coronaal van de GCG. Composietrestauraties hadden een verhoogd risico op secundaire cariës dan amalgaamrestauraties. 
In Hoofdstuk 3 wordt een in vitro studie beschreven waarin onderzocht werd of het gebruikte soort restauratiemateriaal en adhesief de vorming van secundaire cariës in randspleten beïnvloedde. In een kortdurend in vitro biofilm model werden zestig glazuur-dentine blokjes, gerestaureerd met 6 verschillende restauratiematerialen, met en zonder adhesief en een randspleet, getest. Restauratiematerialen die beoordeeld werden, waren: 1) Clearfil AP-X composiet, 2) Clearfil AP-X composiet + SE Bond, 3) Clearfil AP-X composiet + Protect Bond, 4) Filtek Silorane composiet, 5) Filtek Silorane composiet + Silorane System adhesief, and 6) Tytin amalgaam. De proefstukjes werden blootgesteld aan een intermitterend 1\% sucrose biofilm model gedurende 20 dagen om artificiële cariës laesies te creëren. De laesieprogressie in het glazuur en dentine naast de verschillende restauratiematerialen werd gemeten met behulp van Transversal Wavelength Independent Microradiografie (T-WIM). Amalgaam vertoonde geen verminderde secundaire cariës progressie in dentine vergeleken met composietmaterialen. Er was ook geen significant verschil qua cariësontwikkeling tussen de verschillende composietmaterialen. AP-X composiet met Protect Bond vertoonde echter significant minder cariës progressie vergeleken met de onbedekte restauratiematerialen en andere adhesieven.

In de in situ studie van Hoofdstuk 4 werd de ontwikkeling van secundaire cariës in dentine in randspleten naast composiet en amalgaam vergeleken. Gedurende 21 dagen droegen 14 vrijwilligers een gemodificeerde occlusale splint die dentine proefstukjes bevatte die gerestaureerd waren met een gemiddelde randspleet van $215 \mu \mathrm{m}(\mathrm{sd}=55 \mu \mathrm{m})$ en drie verschillende restauratiematerialen: Filtek Supreme composiet, Clearfil AP-X composiet en Tytin amalgaam. Acht keer per dag werd de splint in een 20\% sucrose-oplossing gedoopt gedurende 10 minuten. Voor en na cariësontwikkeling werden de proefstukjes afgebeeld met Transversal Wavelength Independent Microradiografie (T-WIM) en werden de laesiediepte (LD) en mineraalverlies (MV) berekend. De LD en MV van de drie restauratiematerialen werden vergeleken per patiënt, gebruik makende van gepaarde $t$ testen. AP-X composiet had de hoogste LD en MV. Amalgaam vertoonde statistisch significant minder MV ( $\Delta=$ $452 \mu \mathrm{m} . \mathrm{vol} \%)$ dan de gecombineerde composietmaterialen $(\mathrm{p}=0.01)$. Toen amalgaam vergeleken werd met ieder composietmateriaal apart, vertoonde alleen AP-X composiet hoger MV $(\Delta=515 \mu \mathrm{m} . \mathrm{vol} \%)$ dan amalgaam $(\mathrm{p}=0.034)$. Analyse van LD vertoonde dezelfde trends, maar deze waren niet statistisch significant.

De in situ studie van Hoofdstuk 5 onderzocht of er een verband is tussen de breedte van een randspleet en de ontwikkeling van wandlaesies in dentine naast twee composietmaterialen. Tevens werd onderzocht of er een klinisch relevante ondergrens vast te stellen was voor de breedte van de randspleet. Gedurende 21 dagen droegen 14 vrijwilligers een gemodificeerde occlusale splint die dentine proefstukjes bevatte 
die gerestaureerd waren met vijf verschillende breedtes randspleten: 4 randspleten van $50 \mu \mathrm{m}, 100 \mu \mathrm{m}, 200 \mu \mathrm{m}$, of $400 \mu \mathrm{m}$ en 1 niet-gehecht grensvlak zonder randspleet. Voor en na cariësontwikkeling werden de proefstukjes afgebeeld met Transversal Wavelength Independent Microradiografie (T-WIM) en werden de laesiediepte (LD) en mineraalverlies (MV) berekend ter plaatse van de vijf verschillende grensvlakken. Er kon geen verband tussen de breedte van de randspleet en de ontwikkeling van wandlaesies worden gevonden. Een minimum breedte randspleet kon niet worden vastgesteld, maar in een niet-gehecht grensvlak, waarbij geen randspleet te meten was, werd nooit waargenomen dat een wandlaesie zich ontwikkelde.

In Hoofdstuk 6 werd het effect van een hydrodynamische vloeistofstroom, opgewekt door mechanische belasting, op de ontwikkeling van secundaire cariës in vitro onderzocht. Achtenveertig proefstukjes van runderglazuur en dentine werden gerestaureerd met composiet op polystyreen balkjes; 18 proefstukjes werden gehecht met bonding en 30 werden niet gehecht. De proefstukjes werden gedurende 14 dagen in een melkzuuroplossing ( $\mathrm{pH}=5$ ) in een gemodificeerde poetsmachine geplaatst en artificiële cariëslaesies werden gevormd. Gedurende de cariësontwikkeling werden de proefstukjes mechanisch belast aan de kant van het polystyreen balkje op zo'n manier dat het grensvlak van de tand en restauratie werd geopend (16x/min). De belasting was ofwel niets (controlegroep, gebond CB en niet gebond CNB), 200 gram (groep NB200) of 350 gram (NB350 en B350). Voor en na cariësontwikkeling werden de proefstukjes afgebeeld met Transversal Wavelength Independent Microradiografie (T-WIM) en werden de laesiediepte (LD) en mineraalverlies (MV) berekend op vier verschillende meetlocaties. De hoeveelheid belasting en de aanwezigheid van bonding waren statistisch significante factoren in de ontwikkeling van artificiële cariës wandlaesies. Een grotere belasting en de afwezigheid van bonding leidde tot grotere laesies. Deze bevindingen ondersteunen de hypothese dat mechanische belasting in combinatie met een gefaald hechtvlak op het grensvlak van tand en restauratie, door middel van het ontstaan van een hydrodynamische vloeistofstroom, de ontwikkeling van secundaire cariës versnelt.

Tenslotte werd in Hoofdstuk 7 de bestaande literatuur over secundaire cariës en randspleten besproken. De sterke en zwakke punten werden besproken van de verschillende soorten methodologie die gebruikt zijn in dit proefschrift. Op basis van dit proefschrift concluderen we dat de ontwikkeling van secundaire cariës wordt beïnvloed door vele factoren en dat de aanwezigheid van een randspleet slechts één van die factoren is en dat de invloed van de randspleet nog steeds onderwerp van discussie is. 



\section{Dankwoord}

De vijf jaren waarin ik dit proefschrift geschreven heb, waren voor mij een zeer bepalende periode in mijn leven. Een heleboel veranderingen en uitdagingen kwamen op mijn pad die ik van tevoren niet had overzien. leder onderzoek gaat wel gepaard met tegenslagen, maar gelukkig overheersten in mijn onderzoek de successen en kan ik niet navertellen hoeveel taarten ik wel niet heb mogen bakken om deze te vieren. In dit dankwoord wil ik de mensen die mij in dit promotietraject gesteund hebben, graag bedanken.

Prof. dr. M.C.D.N.J.M. Huysmans, beste Marie-Charlotte, wie had ooit gedacht dat ik, tien jaar nadat ik als tandheelkundestudent bij jou kwam voor een proefproject bij de Junior Scientific Masterclass in Groningen, nu hier in Nijmegen onder jouw vleugels mag promoveren. Ik ben je dankbaar dat je van het begin af aan de onderzoeker in mij hebt gezien en vertrouwen in me hebt gehad daar waar ik dat zelf niet altijd had. Dank je voor het vasthouden aan een strakke koers binnen mijn promotieonderzoek. Samen met jou artikelen schrijven, ging altijd zeer snel en efficiënt en jouw correcties in het Engels brachten het artikel altijd weer op een nog hoger niveau. Ik heb je in de afgelopen jaren op persoonlijk vlak steeds beter leren kennen en waardeer je ontzettend. Je bent altijd zeer betrokken geweest bij mijn persoonlijk leven en hebt zeker bijgedragen aan mijn persoonlijke en wetenschappelijke ontwikkeling.

Dr. N.J.M. Opdam, beste Niek, jouw enthousiasme voor onderzoek werkt heel aanstekelijk. Als co-promotor was je een geweldige bron van ideeën. Dankzij jouw database uit Ulft, die je me heel vrijgevig ter beschikking stelde, kon ik vrij snel na de start van mijn promotieonderzoek al een artikel publiceren. Ik waardeer de steun die je me gegeven hebt op de wat moeilijkere momenten van mijn onderzoek zeer. Je voelde me altijd haarfijn aan. Meer dan eens heb je me proberen in te laten zien dat het leven en onderzoek een stuk makkelijker verlopen als ik dingen loslaat. Je wist me altijd weer op te vrolijken en te motiveren om ook bij tegenslagen door te gaan.

Prof. dr. J.A. Jansen, prof. dr. C. van Loveren, prof. dr. H. Meyer-Lückel, beste leden van de manuscriptcommissie, bedankt voor het beoordelen van dit proefschrift, Vielen Dank für die Überprüfung dieser These.

Dr. Ir. E.M. Bronkhorst, beste Ewald, ik blijf me verbazen over jouw snelle geest en ongelooflijke kennis van statistiek. Dankzij jouw goede grappen heb ik veel gelachen, maar op de momenten dat het nodig was, bood jij ook heel goed een luisterend oor. Je bent me zeer dierbaar en ik ben blij dat jij me bijstaat als paranimf. Ik hoop dat we nog lang mogen blijven tafeltennissen. 
Beste Jan Ruben, bedankt voor al jouw hulp op het lab. Jij bent de handigheid zelve en voor ieder probleem heb je wel een oplossing. Dank voor het mij aanleren van jouw mooie T-WIM techniek. Zonder al die T-WIM opnames was mijn onderzoek niet tot stand gekomen. Bedankt voor het aanleveren van de mooie figuren op de voorkant van dit proefschrift.

Beste collega's van ACTA, beste Hans, Mark en Egija, bedankt voor alle uitleg over de microbiologie en de hulp bij het monsteren van de plaquesamples.

Beste Theo Jetten en medewerkers van 4Dental tandtechniek in Arnhem, bedankt voor het ontwikkelen en vervaardigen van de occlusale splints van de in situ studie.

Alle vrijwilligers van de in situ studie, wil ik graag bedanken voor hun doorzettingsvermogen en deelname aan het onderzoek. Uit eigen ervaring weet ik dat het geen makkelijke opgave was om drie weken lang een splint te dragen met proefstukjes in de mond.

Jorien, Rutger, Halima, Bas, Nicole, André, Mark, Bernadette, Lambros, Marçia, Françoise, Anelise, Jovito, Mauro en Kaue, beste kamergenoten, bedankt voor jullie steun en gezelligheid. Jorien, iedere beginnende promovendus zou zo'n collegapromovendus als jij moeten hebben. Jij maakte me in het begin wegwijs en kon alle onderzoeksproblemen altijd heerlijke relativeren en nuanceren. Nicole, ik ben blij dat het weer zo goed met je gaat. Mark en Bernadette, ik waardeer het zeer dat de onderzoeksgroep permanent met jullie is uitgebreid; jullie zijn hele fijne, gezellige collega's waar ik graag nog eens mee op congres ga.

Medewerkers van de vakgroep Preventieve en Curatieve Tandheelkunde en met name Francis en Ineke, bedankt dat jullie me zo warm opnamen in jullie vakgroep. Ik heb me vanaf dag één bij jullie thuis gevoeld.

Dear Max and Tatiana, thank you for your hospitality during my stay in Pelotas, Brasil. Although it must not have been easy to have two guests living in your house while expecting your first baby, you were still so kind to provide for me and Rikkert. Max, thank you for our nice collaboration in working on the in vitro study.

Dear Francoise, thank you for all your help at the laboratory and finishing the in vitro study in Pelotas. 
Dear Anelise, you are my ally in the in situ study. It was quite a lot of work to finish this study, but together we could do this. Thank you for keeping optimistic that everything would be all right (as it did). You are a sweet and very kind person.

Beste Rikkert, bedankt voor de leuke tijd samen in Pelotas, Brazilië. Jij zorgde ervoor dat mijn heimwee naar huis en Nederland iets minder erg werd.

Lieve Liselotte, goede vriendinnen zijn bij mij op een hand te tellen en daar ben jij er één van. Dank je voor alle gezellige weekenden die we hebben doorgebracht. Jij ook heel veel succes met jouw promotieonderzoek. Wat leuk dat we ook nog tegelijk zwanger zijn!

Lieve Marije, ik vind het nog steeds bijzonder dat wij elkaar (weer) ontmoet hebben en wonderlijk hoeveel parallellen wij in onze levens hebben. Na een dag onderzoek doen, kon ik bij jou in de trein altijd alle lief en leed delen. Het is fijn om een vriendin dichtbij te hebben die in hetzelfde schuitje zit en weet wat promoveren inhoudt. Ik kijk uit naar de volgende fase in onze levens. Bedankt dat je mijn paranimf wil zijn!

Lieve papa en mama, jullie hebben mij altijd gestimuleerd het maximale eruit te halen. Studie en ontwikkeling stonden bij jullie hoog in het vaandel en jullie hebben dit ook mogelijk gemaakt. Zonder jullie onvoorwaardelijke support was ik niet zover gekomen. Bedankt voor alle liefde, zorg en steun. De afgelopen periode heeft ons doen beseffen hoe fijn het is dat je als familie gewoon samen kunt zijn.

Lieve Alexandra en Mariska, als zussen heb je een band voor het leven. Ik ben blij dat jullie er altijd zijn op de grote momenten in ons leven. Ik ben dankbaar dat we ondanks de afstand, zulk goed contact hebben en de deur bij een ieder altijd openstaat. Feiko en Bas, wat fijn om jullie in de familie te hebben.

Beste André en Wyke en Lara, jullie waren altijd geïnteresseerd in mijn onderzoek en hebben intens met mij meegeleefd. Ik ben jullie als schoonfamilie heel dankbaar voor jullie betrokkenheid in ons leven.

Tenslotte wil ik de belangrijkste persoon in mijn leven bedanken, mijn lieve echtgenoot. Dennis, je bent mijn grote liefde, steun en toeverlaat. Wat ben ik blij dat ik jou als levensmaatje heb. Ik kan en mag bij jou mezelf zijn. Je bent er altijd voor mij (dag en nacht) en je vult mij aan in precies die dingen die ik het hardste nodig heb. We hebben een heel fijn huwelijk en dit wordt binnenkort bekroond met de geboorte van ons eerste kindje. Ik hou van je! 



\section{Curriculum Vitae}

Nicolien Kuper werd op 24 augustus 1985 te Emmen geboren. In 2003 haalde zij haar gymnasiumdiploma (profiel Natuur \& Gezondheid) aan het Esdal College te Emmen. In september van dat jaar begon zij aan haar studie tandheelkunde aan de Rijksuniversiteit Groningen. Op 4 juli 2008 ontving zij haar tandartsbul. Na haar afstuderen werkte zij een jaar lang in twee verschillende tandartspraktijken te Groningen en als coach professionalisering bij de opleiding Tandheelkunde te Groningen. Op 1 november 2009 begon zij aan haar promotietraject op de afdeling Preventieve en Curatieve Tandheelkunde van het Radboudumc in Nijmegen.

Per 1 november 2014 is zij aangesteld als post-doc bij de afdeling Preventieve en Curatieve Tandheelkunde waar zij haar onderzoek naar secundaire cariës zal voortzetten. Tevens werkt zij als tandarts in twee tandartspraktijken, zowel in Deventer als in Zutphen. Op 16 september 2011 is zij getrouwd met Dennis de Vries en rond 14 mei 2015 verwachten zij hun eerste kindje. 
